Prepared in cooperation with the Wisconsin Department of Transportation and the Wisconsin Department of Natural Resources

\title{
Parking Lot Runoff Quality and Treatment Efficiency of a Stormwater-Filtration Device, Madison, Wisconsin, 2005-07
}

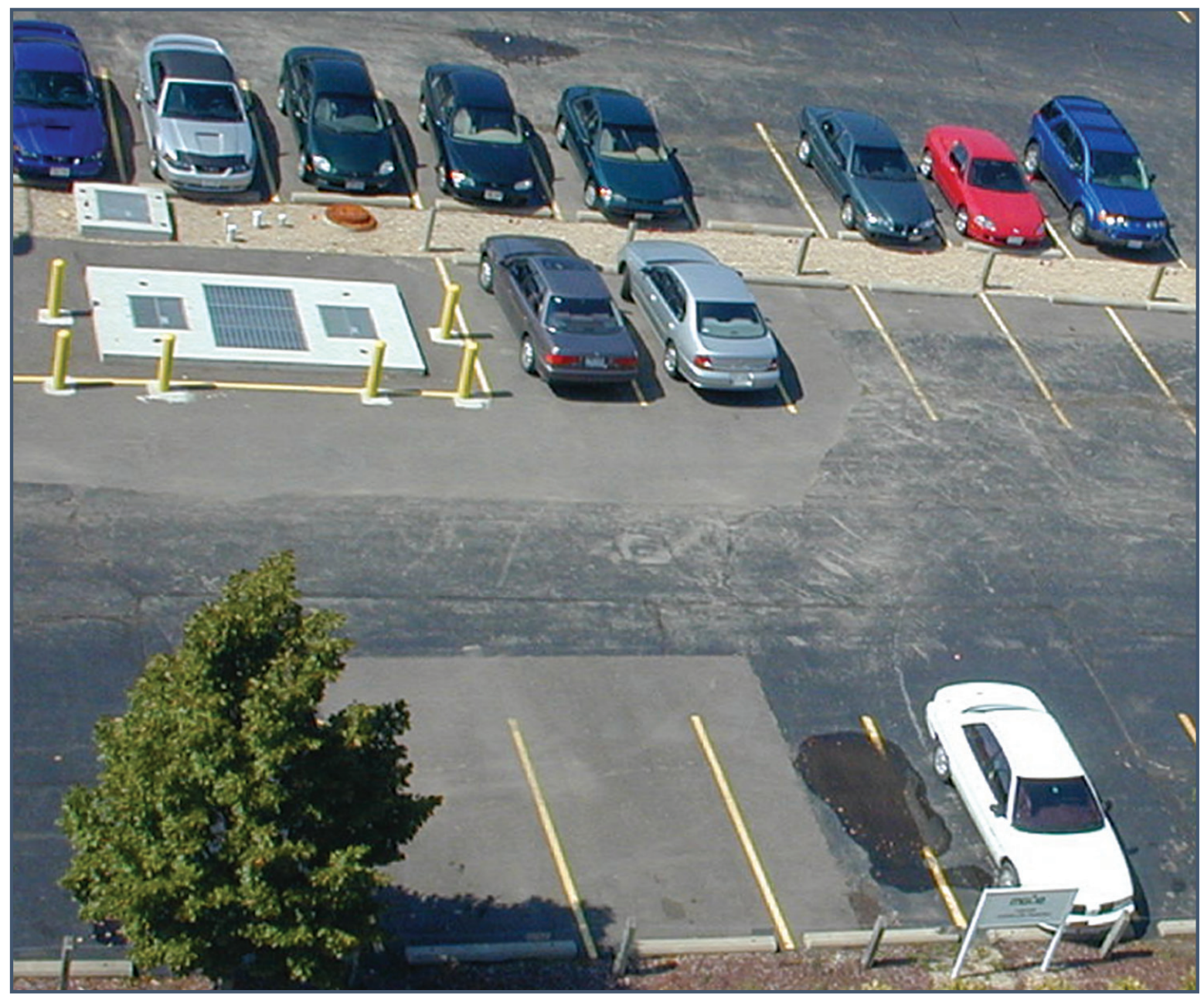

Scientific Investigations Report 2009-5196 
Cover: A stormwater-filtration device installed in an employee parking lot in downtown Madison, Wisconsin. (Photograph from Earth Tech, Inc., September 2004.) 


\section{Parking Lot Runoff Quality and Treatment Efficiency of a Stormwater-Filtration Device, Madison, Wisconsin, 2005-07}

By Judy A. Horwatich and Roger T. Bannerman

Prepared in cooperation with the Wisconsin Department of Transportation and the Wisconsin Department of Natural Resources

Scientific Investigations Report 2009-5196

U.S. Department of the Interior

U.S. Geological Survey 


\section{U.S. Department of the Interior \\ KEN SALAZAR, Secretary \\ U.S. Geological Survey \\ Marcia K. McNutt, Director}

U.S. Geological Survey, Reston, Virginia: 2010

For more information on the USGS—-the Federal source for science about the Earth, its natural and living resources,
natural hazards, and the environment, visit http://www.usgs.gov or call 1-888-ASK-USGS
For an overview of USGS information products, including maps, imagery, and publications,
visit http://www.usgs.gov/pubprod
To order this and other USGS information products, visit http://store.usgs.gov

Any use of trade, product, or firm names is for descriptive purposes only and does not imply endorsement by the U.S. Government.

Although this report is in the public domain, permission must be secured from the individual copyright owners to reproduce any copyrighted materials contained within this report.

Suggested citation:

Horwatich, J.A., and Bannerman, R.T., 2010, Parking lot runoff quality and treatment efficiency of a stormwater-filtration device, Madison, Wisconsin, 2005-07: U.S. Geological Survey Scientific Investigations Report 2009-5196, 50 p. 


\section{Contents}

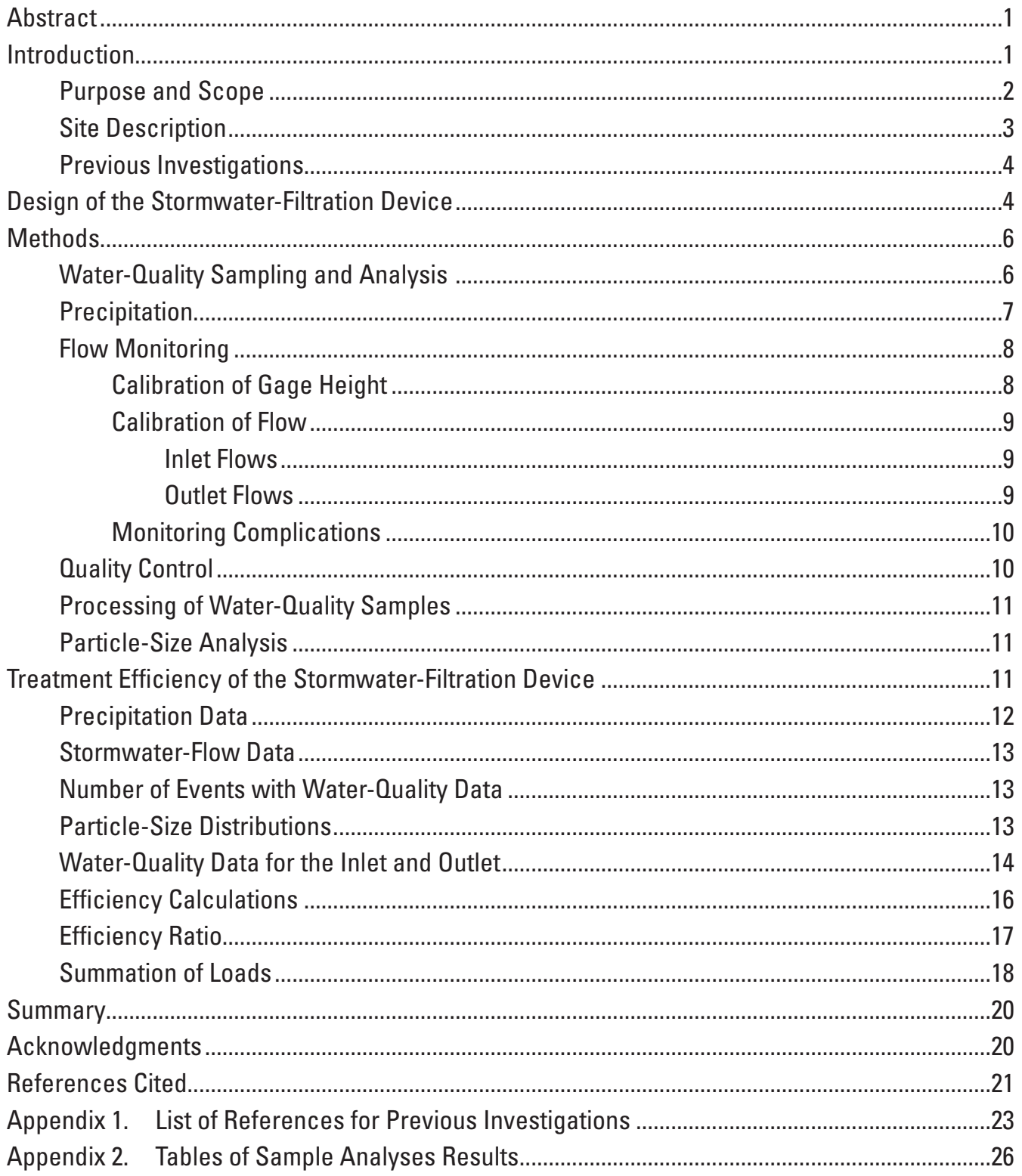

\section{Figures}

1. Aerial photograph showing the study area including the drainage area of the parking lot, and location of the islands, manholes, and flow-splitter box and storm-sewer pipes

2. Photograph showing the flow-splitter box upstream from the stormwater-filtration device, representing the inlet pipe, the overflow weir, and the bypass pipe 
3. Diagram showing the components of the stormwater-filtration device

4-6. Photographs showing:

4. The flow spreader and the modification made to the internal bypass weir of the stormwater-filtration device

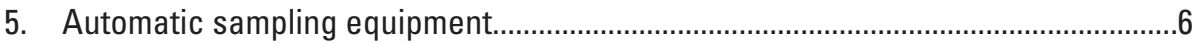

6. Inlet pipe with stabilization bar

7. Graph showing dye-dilution flow in relation to area-velocity flow at the inlet of the stormwater-filtration device.

8. Photograph showing the dye-dilution equipment .......................................................10

9. Graph showing the cumulative precipitation for the study period (2005-07) in relation to the cumulative frequency for all precipitation greater than 0.19 inches (1949-92) based on the National Oceanic and Atmospheric Administration precipitation gage at Dane County Regional Airport, Madison, Wis......13

10. Graph showing the stormwater volumes at the inlet of the stormwaterfiltration device corrected by dye dilution in relation to outlet volumes, Madison, Wis., 2007

\section{Tables}

1. Limits of detection and analytical methods for inorganic constituents analyzed in samples collected at the stormwater-filtration device, Madison, Wis.

2. Limits of detection and analytical methods for polycyclic aromatic hydrocarbons analyzed in samples collected at the stormwater-filtration device, Madison, Wis.

3. Monthly precipitation at the U.S. Geological Survey raingage and the National Oceanic and Atmospheric Administration precipitation gage at the Dane County Regional Airport, Madison, Wis., 2005-07.

4. Average particle-size distribution in stormwater samples collected from the inlet and outlet of a stormwater-filtration device, Madison, Wis.

5. Summary statistics for selected water-quality constituents in samples collected from a stormwater-filtration device, Madison, Wis.

6. Summary statistics for individual polycyclic aromatic hydrocarbons in 15 samples collected from a stormwater-filtration device, Madison, Wis.

7. Efficiency ratios for selected constituents in samples from a stormwaterfiltration device, Madison, Wis., 2005-07

8. Efficiency ratios for selected polycyclic aromatic hydrocarbons in samples from a stormwater-filtration device, Madison, Wis., 2005-07.

9. Summation of loads of selected constituents and percent efficiency for a stormwater-filtration device, Madison, Wis., 2005-07

2-1. Concentrations of selected constituents in equipment-field-blank data collected from a stormwater-filtration device, Madison, Wis., 2005-07.

2-2. Relative percent difference for concentrations of selected constituents in field replicate samples collected from a stormwater-filtration device and sample, Madison, Wis., 2005-07

2-3. Precipitation during sampling events from a stormwater-filtration device, Madison, Wis., 2005-07.

2-4. Outlet flow volumes, percent runoff, and peak discharge for sampled events at a stormwater-filtration device, Madison, Wis., 2005-07. 
2-5. Concentrations of suspended solids, suspended sediment, volatile solids, and dissolved solids in stormwater samples collected from a stormwater-filtration device, Madison, Wis., 2005-07 .

2-6. Concentrations of selected constituents and physical properties in stormwater samples collected from a stormwater-filtration device, Madison, Wis., 2005-07

2-7. Mean concentrations of selected polycyclic aromatic hydrocarbons in samples collected from a stormwater-filtration device, Madison, Wis., 2005-07.

2-8. Particle-size distributions in samples collected from a stormwater-filtration device, Madison, Wis., 2005-07 .

2-9. Loads of suspended solids, suspended sediment, volatile solids, and dissolved solids in stormwater samples collected from a stormwater-filtration device, Madison, Wis., 2005-07 ...

2-10. Loads of selected constituents in stormwater samples collected from a stormwater-filtration device, Madison, Wis., 2005-07

2-11. Loads of selected polycyclic aromatic hydrocarbons in stormwater samples collected from a stormwater-filtration device, Madison, Wis., 2005-07

2-12. Parking lot comparison of geometric concentrations from several studies in Wisconsin

\section{Conversion Factors and Abbreviations}

\begin{tabular}{|c|c|c|}
\hline Multiply & By & To obtain \\
\hline \multicolumn{3}{|c|}{ Length } \\
\hline inch (in.) & 2.54 & centimeter $(\mathrm{cm})$ \\
\hline foot (ft) & 0.3048 & meter $(\mathrm{m})$ \\
\hline mile (mi) & 1.609 & kilometer $(\mathrm{km})$ \\
\hline millimeter (mm) & 0.03937 & inch (in.) \\
\hline \multicolumn{3}{|c|}{ Area } \\
\hline acre & 4,047 & square meter $\left(\mathrm{m}^{2}\right)$ \\
\hline square foot $\left(\mathrm{ft}^{2}\right)$ & 929.0 & square centimeter $\left(\mathrm{cm}^{2}\right)$ \\
\hline \multicolumn{3}{|c|}{ Volume } \\
\hline gallon (gal) & 3.785 & liter $(\mathrm{L})$ \\
\hline gallon (gal) & 0.003785 & cubic meter $\left(\mathrm{m}^{3}\right)$ \\
\hline cubic foot $\left(\mathrm{ft}^{3}\right)$ & 0.02832 & cubic meter $\left(\mathrm{m}^{3}\right)$ \\
\hline liter $(\mathrm{L})$ & 61.02 & cubic inch $\left(\mathrm{in}^{3}\right)$ \\
\hline \multicolumn{3}{|c|}{ Flow rate } \\
\hline foot per second (ft/s) & 0.3048 & meter per second $(\mathrm{m} / \mathrm{s})$ \\
\hline cubic foot per second $\left(\mathrm{ft}^{3} / \mathrm{s}\right)$ & 0.02832 & cubic meter per second $\left(\mathrm{m}^{3} / \mathrm{s}\right)$ \\
\hline gallon per minute (gal/min) & 0.06309 & liter per second $(\mathrm{L} / \mathrm{s})$ \\
\hline milliliter per second $(\mathrm{mL} / \mathrm{s})$ & .00003531 & cubic foot per second $\left(\mathrm{ft}^{3} / \mathrm{s}\right)$ \\
\hline \multicolumn{3}{|c|}{ Mass } \\
\hline pound, avoirdupois (lb) & 0.4536 & kilogram (kg) \\
\hline gram (g) & 0.03527 & ounce, avoirdupois (oz) \\
\hline
\end{tabular}


Temperature in degrees Fahrenheit $\left({ }^{\circ} \mathrm{F}\right)$ may be converted to degrees Celsius $\left({ }^{\circ} \mathrm{C}\right)$ as follows:

${ }^{\circ} \mathrm{C}=\left({ }^{\circ} \mathrm{F}-32\right) / 1.8$

Concentrations of chemical constituents in water are given either in milligrams per liter (mg/L) or micrograms per liter ( $\mu \mathrm{g} / \mathrm{L})$.

Particle sizes of sediment are given in micrometers $(\mu \mathrm{m})$. A micrometer is one-thousandth of a millimeter.

Concentrations of sieved solids as a dried weight are in milligrams per kilogram $(\mathrm{mg} / \mathrm{kg})$.

\section{Abbreviations used in this report}

$\mathrm{Cl}$

chloride

COD

chemical oxygen demand

DCRA

Dane County Regional Airport

DCOD

dissolved chemical oxygen demand

$\mathrm{DCu}$

dissolved copper

DP

dissolved phosphorus

DZn

dissolved zinc

EMC

event mean concentration

LOQ

limit of quantification

MCTT

Multi-Chamber Treatment Tank

NOAA

National Oceanic and Atmospheric Administration

NURP

Nationwide Urban Runoff Program

$\mathrm{PAH}$

polycyclic aromatic hydrocarbon

PSD

particle-size distribution

QA/QC

quality-assurance/quality-control

RPD

relative percent difference

SFD

stormwater-filtration device

SOL

summation of loads

SRS

standard reference sample

SS

suspended sediment

$\mathrm{TCu}$

total copper

TDS

total dissolved solid

TP

total phosphorus

TSS

total suspended solid

TZn

total zinc

USEPA

U.S. Environmental Protection Agency

USGS

U.S. Geological Survey

WDNR

Wisconsin Department of Natural Resources

WisDOT Wisconsin Department of Transportation

WinSLAMM Windows Source Load and Management Model

WSLOH

Wisconsin State Laboratory of Hygiene 


\title{
Parking Lot Runoff Quality and Treatment Efficiency of a Stormwater-Filtration Device, Madison, Wisconsin, 2005-07
}

\author{
By Judy A. Horwatich and Roger T. Bannerman
}

\section{Abstract}

To evaluate the treatment efficiency of a stormwaterfiltration device (SFD) for potential use at Wisconsin Department of Transportation (WisDOT) park-and-ride facilities, a SFD was installed at an employee parking lot in downtown Madison, Wisconsin. This type of parking lot was chosen for the test site because the constituent concentrations and particle-size distributions (PSDs) were expected to be similar to those of a typical park-and-ride lot operated by WisDOT. The objective of this particular installation was to reduce loads of total suspended solids (TSS) in stormwater runoff to Lake Monona. This study also was designed to provide a range of treatment efficiencies expected for a SFD. Samples from the inlet and outlet were analyzed for 33 organic and inorganic constituents, including 18 polycyclic aromatic hydrocarbons (PAHs). Samples were also analyzed for physical properties, including PSD. Water-quality samples were collected for 51 runoff events from November 2005 to August 2007. Samples from all runoff events were analyzed for concentrations of suspended sediment (SS). Samples from 31 runoff events were analyzed for 15 constituents, samples from 15 runoff events were analyzed for PAHs, and samples from 36 events were analyzed for PSD.

The treatment efficiency of the SFD was calculated using the summation of loads (SOL) and the efficiency ratio methods. Constituents for which the concentrations and (or) loads were decreased by the SFD include TSS, SS, volatile suspended solids, total phosphorous (TP), total copper, total zinc, and PAHs. The efficiency ratios for these constituents are $45,37,38,55,22,5$, and 46 percent, respectively. The SOLs for these constituents are 32,37, 28, 36, 23, 8, and 48 percent, respectively. The SOL for chloride was -21 and the efficiency ratio was -18 . Six chemical constituents or properties - dissolved phosphorus, chemical oxygen demand, dissolved zinc, total dissolved solids, dissolved chemical oxygen demand, and dissolved copper-were not included in the efficiency or SOL, because the difference between

\footnotetext{
' Wisconsin Department of Natural Resources
}

concentrations in samples from the inlet and outlet were not significant. Concentrations of TP and TSS were inexplicably high in samples at the inlet for one event.

\section{Introduction}

An Administrative Rule has been established by the Wisconsin Department of Transportation (WisDOT) (Wisconsin Administrative Code, 2002) to control the stormwaterquality runoff from transportation facilities, such as highways, airports, and railroads. The rule was established to comply with the administrative rules for non-agricultural and runoffmanagement performance standards established by the Wisconsin Department of Natural Resources (WDNR) (Wisconsin Administrative Code, 2004). A major element of the administrative rule is the control of total suspended solids (TSS) in stormwater runoff from post-construction sites and developed urban areas. For new development, the performance standard requires that loads of TSS be reduced by at least 80 percent for those facilities constructed after January 1, 2003 (Wisconsin Administrative Code, 2002). The rule requires a performance standard of at least a 40-percent reduction in loads of TSS for highway reconstruction and non-highway redevelopment (Wisconsin Administrative Code, 2002). To evaluate post-construction performance, the WDNR allows the use of a computer simulation model, such as the Windows Source Load and Management Model (WinSLAMM) to determine TSS load reduction. In addition, the U.S. Environmental Protection Agency Phase I and Phase II stormwater regulations result in additional focus on the quality of flow from transportation facilities (U.S. Environmental Protection Agency, 2000).

To find the most cost-effective ways of complying with the TSS performance standard, WisDOT has supported evaluations of several devices that reduce contaminants from freeways. These include street-cleaning devices evaluated in Milwaukee (Waschbusch, 2003) and Madison (Wendy Braun, Wisconsin Department of Transportation, written commun., 2006). Two prefabricated devices were evaluated in Milwaukee; these include a stormwater-filtration device (SFD) (similar to the one used in this study) and a hydrodynamic settling device (U.S. Environmental Protection Agency, 2004; 2005). 
To evaluate the treatment efficiency of a SFD for WisDOT transportation facilities - for example, a park-and-ride lot - a SFD was installed in an employee parking lot. The objective of this particular installation was to reduce loads of TSS in stormwater runoff to Lake Monona. This site has a similar rate of usage as a park-and-ride lot. Because the WisDOT has already tested a SFD that treated runoff from a freeway, it was considered important to select a WisDOT facility with different levels of contaminants and a different distribution of mean particle size from those at the freeway site. Therefore, WisDOT, Madison Gas and Electric Company (MGE) (owner of the parking lot), WDNR, and the U.S. Geological Survey (USGS) developed this cooperative study to determine the reductions of contaminants when a SFD is used at a typical parking lot facility. This study also was designed to provide a range of treatment efficiencies expected for a SFD.

A SFD is among the emerging prefabricated stormwatercontrol devices designed to provide at least a 40-percent reduction of TSS without requiring a lot of space. Space can be a limitation at some transportation facilities, such as parkand-ride lots in highly urbanized areas. Many facilities in highly urbanized areas will need to meet the 40-percent TSS performance standard at redevelopment sites and in developed urban areas. To save space, most of the devices are installed underground or above ground as a landscaping feature. Because single-chamber settling devices, such as catchment basins, have not achieved TSS reductions of 40 percent (Waschbusch, 1999; U.S. Environmental Protection Agency, 2005), most of the newer devices incorporate filters to achieve higher levels of TSS reduction in a relatively small space.

Bioretention systems and Multi-Chamber Treatment Tanks (MCTTs) are two examples of newer non-structural stormwater-control devices using filtration as part of the treatment process (Prince George's County, 2002; Pitt and others, 1999). Bioretention systems are a landscaping feature capable of reducing the TSS load by at least 80 percent (Hunt, 2006). This stormwater-control feature usually has a mixture of sand, compost, and native soil that is $3 \mathrm{ft}$ thick and serves drainage areas of less than 2 acres. More study would be needed of the maintenance requirements, filter thicknesses, and mixture to improve TSS reduction. Bioretention systems are gaining widespread acceptance in Wisconsin as a method for treating stormwater runoff from parking lots. A 98-percent load reduction in TSS was achieved by an MCTT installed underground in a maintenance yard in Milwaukee, Wisconsin (Corsi and others, 1999). The MCTT contained a mixture of sand, peat moss, and activated carbon. Because limited technical and maintenance support are available, MCTTs have been installed in only a few places around the country.

Prefabricated devices are an alternative to the non-structural ones. Advantages to using prefabricated devices include technical support from the manufacturer and they are usually designed for easy maintenance. However, the TSS reductions for these devices have not been verified and any testing has been limited by site-specific characteristics of the stormwater runoff.
Prefabricated filtration devices installed underground have achieved at least a 40-percent reduction in TSS load at a hospital parking lot in Green Bay, Wisconsin, and on a freeway in Milwaukee, Wisconsin (Horwatich and others, 2004; U.S. Environmental Protection Agency, 2004). A prefabricated pressurized sand filter reduced the TSS load by 80 percent in runoff from a hospital parking lot. The SFD at the freeway site reduced the TSS load by 50 percent.

The ability of the SFD to exceed a 40-percent TSS load reduction at a freeway site does not guarantee that the filter will achieve the same level of TSS load reduction at other types of WisDOT facilities, such as park-and-ride lots and maintenance yards. Each type of facility may have different levels of contaminants and particle-size distributions. Testing the SFD at the employee parking lot in Madison will help quantify the efficiencies of using this filter at park-and-ride lots. It also may provide the additional data needed to calibrate and verify the SFD efficiency equations in an urban stormwater-runoff model.

\section{Purpose and Scope}

This report describes the process of monitoring stormwater runoff at the inlet, outlet, and bypass pipes of a stormwaterfiltration device installed at an employee parking lot in downtown Madison, Wis. The report also describes the methods for determining the efficiency of the device.

Precipitation, flow-volume, particle-size, and concentration data collected from November 5, 2005, to August 18, 2007, are reported. Precipitation erosivity, antecedent dry days, and peak flow data are presented in appendixes. Precipitation, flow volume, and concentrations of suspended sediment were recorded for 51 storm events. Concentrations in samples collected during 31 runoff events are reported for 15 constituents analyzed including dissolved and particulate solids, inorganic compounds, organic compounds, and recoverable metals. Particle-size distributions are presented for 36 runoff events and concentrations of 18 polycyclic aromatic hydrocarbons (PAHs) are presented for 15 runoff events.

New methods are presented for determining particle-size distributions and processing samples with a churn splitter are presented. Constituent concentrations in samples from the SFD inlet were compared with concentrations from other source areas, such as a high-turnover parking lot at a hospital.

A goal of the current project was to verify the results of the WinSLAMM model. Data from the parking lot study and the Milwaukee freeway studies can be modeled in WinSLAMM using TSS reduction devices. For example, WinSLAMM simulates hydrodynamic settling devices (such as the one evaluated in Milwaukee) utilizing Stokes law equation, which is based on particle-size distribution and flow velocity to determine the particle-size dropout rate through the device (Pitt, 2003). The efficiency of other stormwater-control devices can be affected depending on which particle-size distribution is applied in the model. The manufacturer of the 
SFD used in the study and the developers of WinSLAMM are cooperatively designing the algorithm to include their SFDs in the model. If the calibration and verification are successful, the model could be used to estimate the efficiencies from a SFD at any transportation facility when appropriate source-area data are available.

This report also adds to the understanding of stormwater quality and quantity in an urban environment. Concentrations of constituents in samples from storm-sewer inlets are compared with concentrations from other types of source areas, such as a high-turnover parking lot at a hospital. These results help identify the relative importance of different source areas and characterize the potential impact of the stormwater on receiving waters.

\section{Site Description}

In June 2003, MGE installed a stormwater-filtration device called a StormFilter at an employee parking lot in downtown Madison, Wis. (fig. 1). The filter cartridges were replaced in May 2005, just before sampling began. The area of the parking lot was originally determined to be 1.3 acres (using an available surface-elevation map) but was later revised to 0.91 acres. The asphalt parking lot has 181 parking stalls occupied mostly by employees' cars with a few stalls for visitor parking. On weekends and weeknights, the parking lot is used for overflow parking of downtown businesses. Most contaminants deposited on the parking lot are delivered by cars and atmospheric deposition. Salt is applied in the winter as needed. Stormwater from the site flows from a 15 -in. stormsewer pipe, then into a 48 by 76 -in. storm-sewer culvert, and then flows to Lake Monona. The maintenance plan for the parking lot states that a layer of seal coat is to be applied periodically. A seal coat of coal tar was last applied in 2000 (James Montgomery, Madison Gas and Electric Company, oral commun., 2006).

The parking lot is divided into three areas, and each area has about the same number of stalls. A 4-ft-wide gravel island separates the areas from each other, and there is an island at each end of the parking lot. When parked, all the cars face an island. Stormwater draining from the parking lot flows into storm-sewer grates in the north and south islands. These grates are attached to a 15 in.-diameter storm-sewer pipe that flows to the SFD (fig. 1).

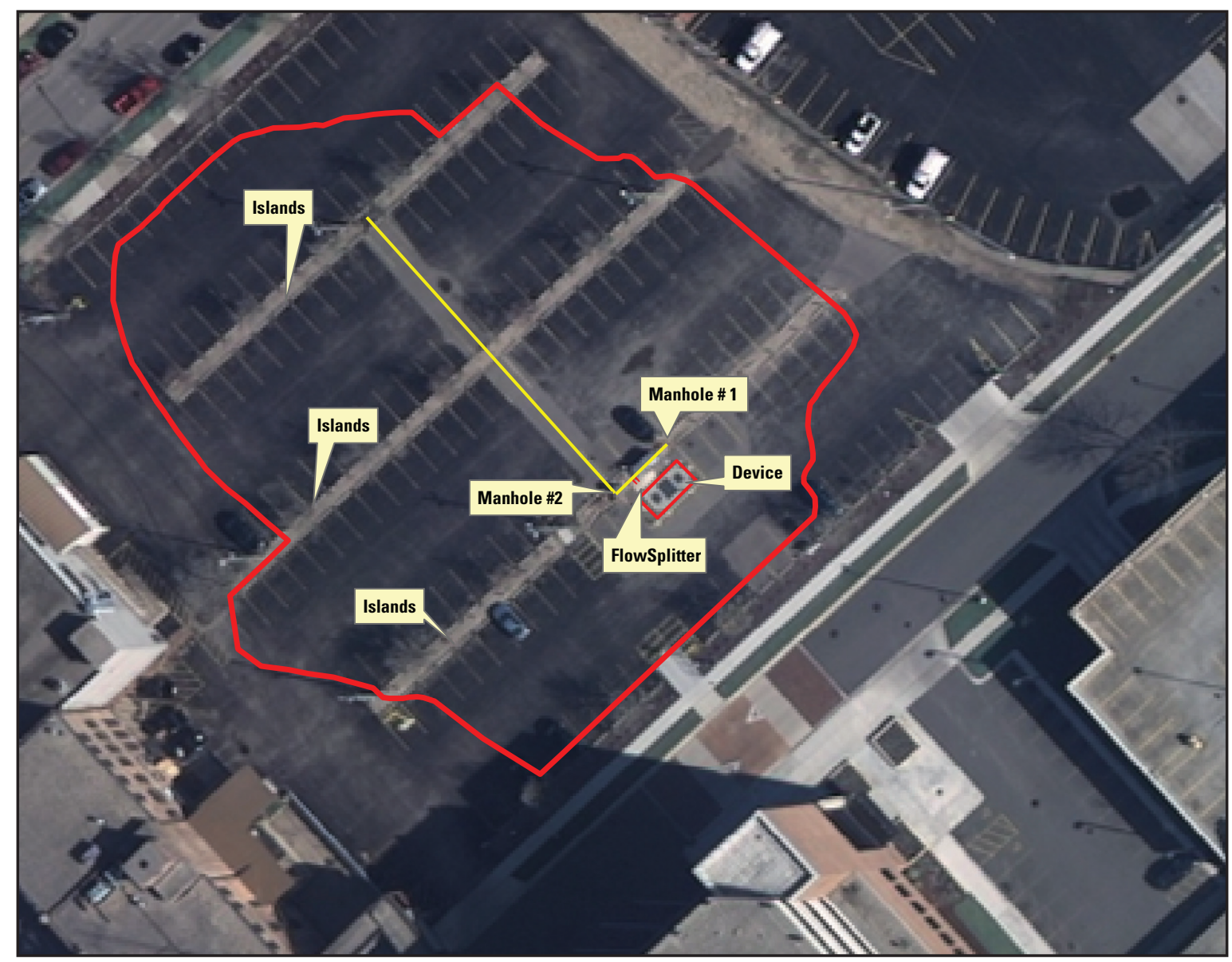

Figure 1. Study area including the drainage area of the parking lot (outlined in red), and location of the islands, manholes, and flow-splitter box and storm-sewer pipes (lined in yellow). 
The gravel islands do not have curbs, so the stormwater from the parking lot can flow into the islands. Underneath the gravel is a sheet of thick black plastic. An inspection revealed that holes have developed in the plastic, which could allow additional infiltration through the islands. The gravel islands consist of 0.06 acres. The islands probably contribute runoff during large, intense runoff events but store water during small events.

The parking lot was built in 1986. Over time, depressions have formed in the pavement. Small depressions have formed in many of the stalls where the wheels of cars sit. Larger depressions have formed in the driving lanes between stalls. Deposited sediment was observed in most of the depressions. Puddles formed in these depressions after rainfall.

Underneath the parking lot, the soil profile from bottom upward consists of a fibrous peat and organic soil mixture at $7.5 \mathrm{ft}$; above that is $5.5 \mathrm{ft}$ of fill material consisting of dark brown silty sand with pebbles. The next layer is $1.25 \mathrm{ft}$ of fill material, consisting of concrete rubble with sand; above that is a base course $7 \mathrm{in}$. deep. The parking lot surface layer is $2 \mathrm{in}$. of asphaltic concrete. The water table is approximately $6 \mathrm{ft}$ below the parking lot.

\section{Previous Investigations}

The USGS has a long history of conducting urban water-quality investigations in Wisconsin. In 1978, the U.S. Environmental Protection Agency (USEPA) established the Nationwide Urban Runoff Program (NURP) to assess the water-quality characteristics of urban runoff. When the city of Milwaukee, Wis., was chosen by the USEPA as a NURP site, a partnership between the WDNR and the USGS was developed to evaluate urban runoff in Milwaukee. Since the NURP study, the USGS and the WDNR have continued their partnership and have completed more than 15 studies in at least 6 cities to assist the State of Wisconsin in characterization of urban stormwater runoff. See appendix 1 for a list of references for these investigations.

\section{Design of the Stormwater-Filtration Device}

The SFD removes contaminants through filtration and sedimentation. Filtration, considered the primary method of treatment, is done by means of a filter media that physically removes particles by retaining contaminants through sorption. Each of the 26 filter cartridges in the SFD was filled with ZPG media, a mixture of zeolite, perlite, and granular activated carbon. The filter media was designed to remove sediments, recoverable metals, organic compounds, phosphorus, oils, and greases. Sedimentation of larger particles occurs in a pretreatment chamber and on the bottom of the cartridge-filter bay.
The device was designed to treat stormwater runoff from an impervious area of 1.3 acres, but runoff coefficients measured during the study indicated that the drainage area had not been determined correctly. The runoff coefficients using the 1.3 acres averaged about 40 percent, which was much lower than the expected runoff coefficients-around 70 percent (Horwatich and others, 2004). The correct drainage-area divides were determined by watching the direction of flow when water was applied with a hose. The correct area of the watershed was 0.91 acres; therefore, the SFD was over-sized for the site.

Stormwater from the parking lot enters into a precast 4-ftlong flow-splitter-box manhole (figs. 1 and 2). An adjustable external-weir plate is set in the center of the box at a height of $2.17 \mathrm{ft}$. At 90 degrees from of the weir plate, a 6-in.-diameter low-flow inlet pipe transfers stormwater into the device (fig. 2). If the stormwater rises more than $2.17 \mathrm{ft}$ in the flowsplitter box, it bypasses the SFD through a 15-in.-diameter pipe; this stormwater is not treated.

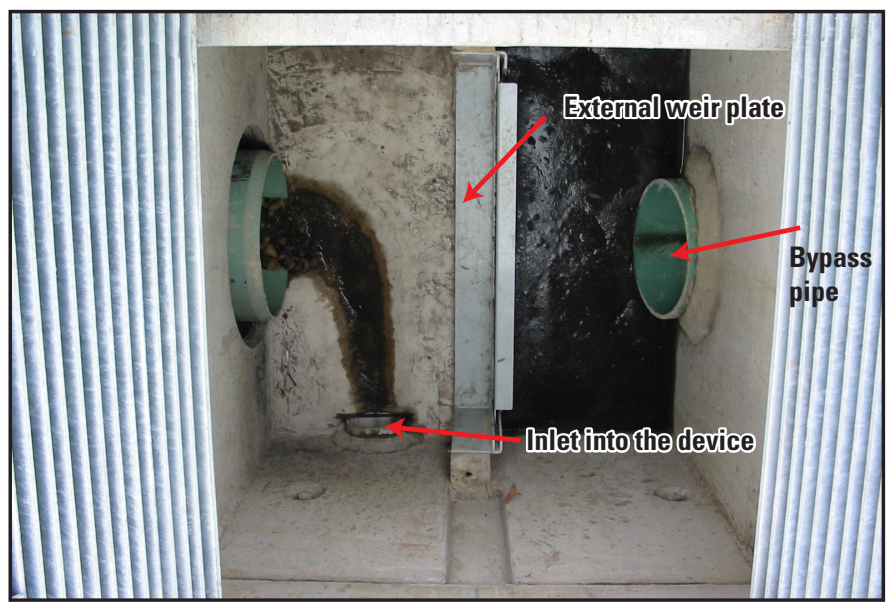

Figure 2. Flow-splitter box upstream from the stormwaterfiltration device, representing the inlet pipe, the overflow weir, and the bypass pipe (top view).

The SFD was housed in a concrete structure that was 6 in. thick, $16 \mathrm{ft}$ long, $8 \mathrm{ft}$ wide, and $5.5 \mathrm{ft}$ deep (fig. 3). Stormwater enters from the inlet pipe into a $2 \mathrm{ft}$ wide, $1.67 \mathrm{ft}$ deep inlet bay, which acts as a pretreatment chamber and energy dissipater (fig. 4). It then flows through a flow spreader that disperses water evenly into a 7.4-ft-long cartridge bay.

Flow rates were controlled through the filter cartridges by a siphon action, and the water exited the cartridge through an underdrain manifold. Each cartridge was designed to treat a peak flow of $0.033 \mathrm{ft}^{3} / \mathrm{s}$, and combined, the cartridges could treat a peak flow of $0.87 \mathrm{ft}^{3} / \mathrm{s}$. When inlet flows exceeded $0.87 \mathrm{ft}^{3} / \mathrm{s}$, water bypassed the filter cartridges by way of the high-flow bypass weir at a height of $1.83 \mathrm{ft}$ (fig. 3). Treated water from the underdrain manifold and untreated internal bypass water entered the outlet bay area $(8 \mathrm{ft}$ long by $2.3 \mathrm{ft}$ wide) and then flowed through a 6-in.-diameter outlet pipe (James Bachhuber, Earth Tech, written commun., 2004). 


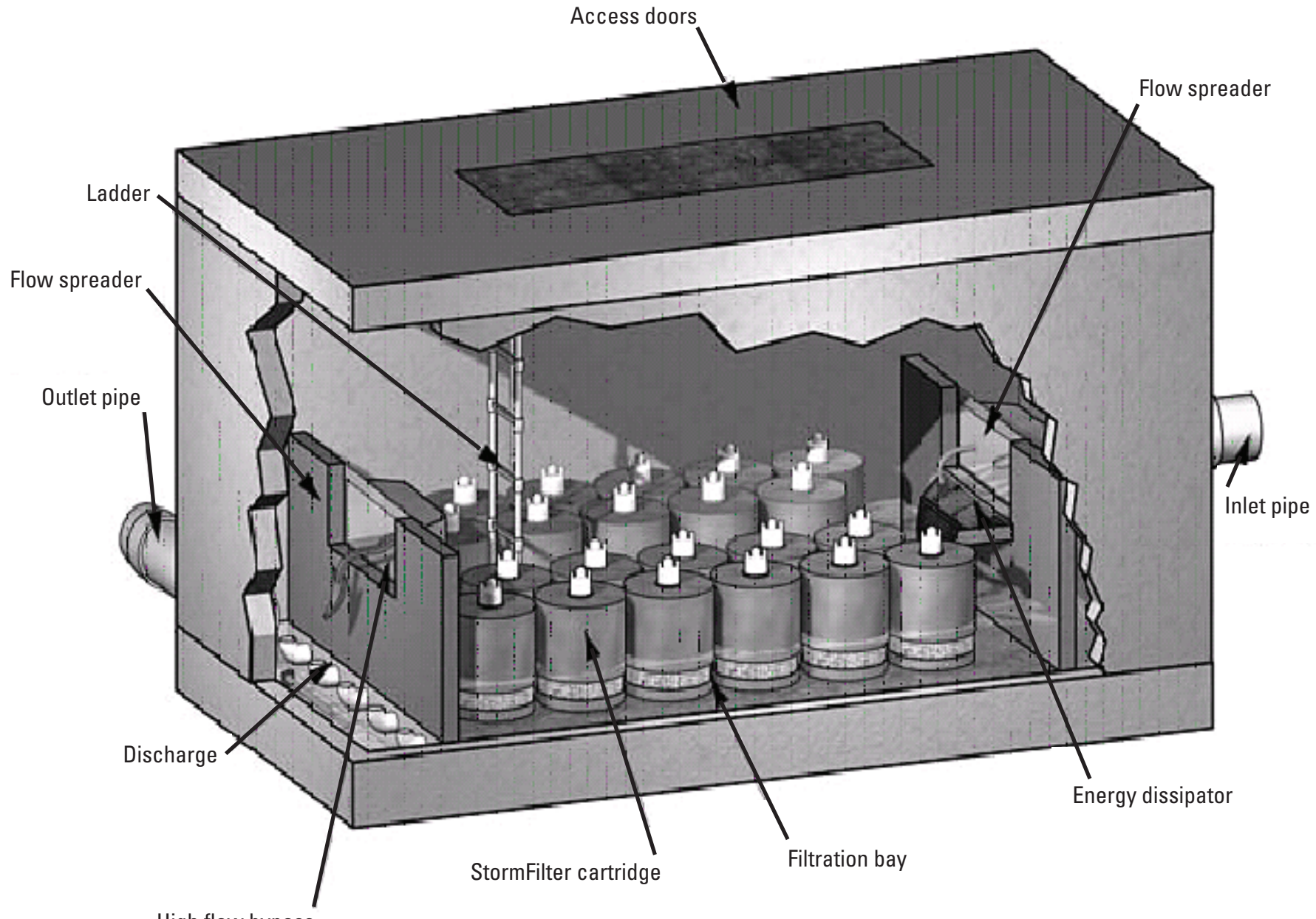

High flow bypass

Figure 3. Components of the stormwater-filtration device (U.S. Environmental Protection Agency, 2004).

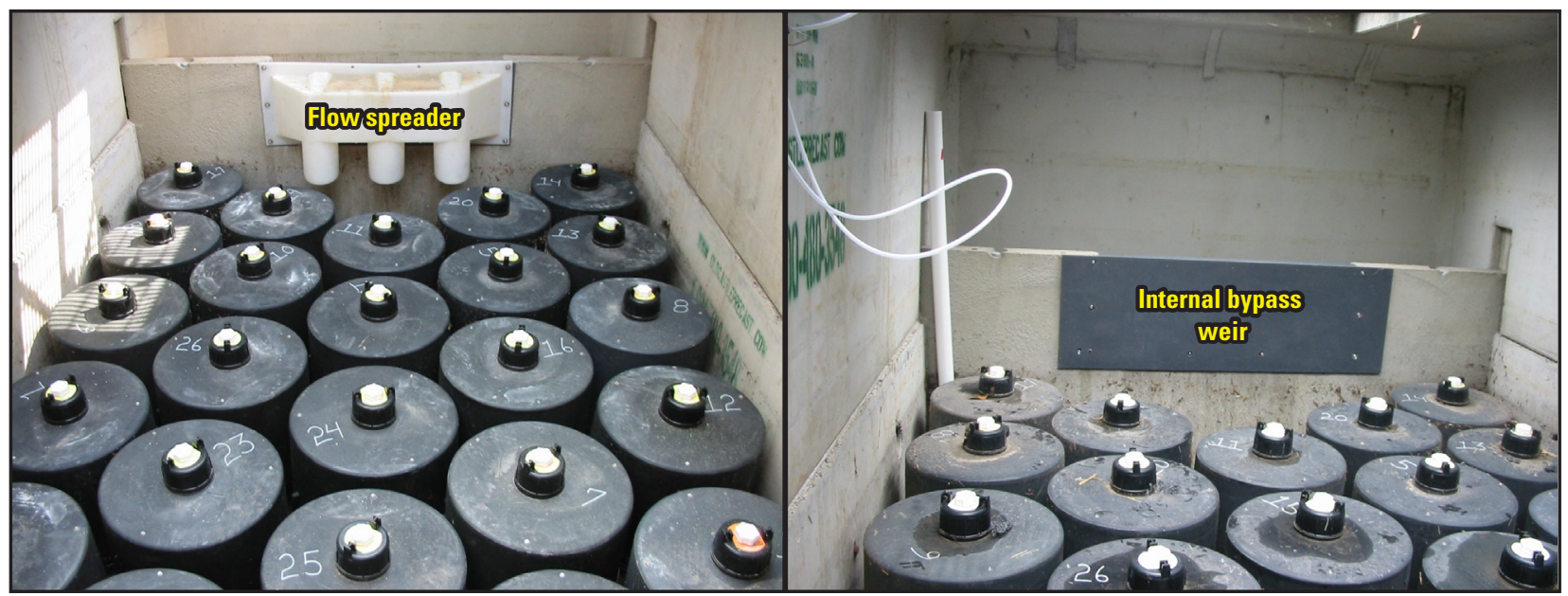

Figure 4. The flow spreader and the modification made to the internal bypass weir of the stormwater-filtration device. Each black cylinder contains a filter cartridge. 
The manufacturer recommended that sediment be removed from the pretreatment chamber as necessary and that the filters be inspected once a year to determine whether replacement was needed. However, the filters did not need replacement during the project in part for the following reasons: (1) the device was designed to treat runoff from 1.3 acres rather than the effective runoff area of 0.91 acres, and (2) the removal efficiencies of the device were not observed to diminish during the monitoring period. Personnel from the manufacturer inspected the SFD on August 17, 2007, the day after sampling was completed, and determined the device remained in good working order.

\section{Methods}

Stormwater runoff was measured and collected at the inlet, outlet, and bypass pipes of the SFD. Each pipe was equipped with automated stormwater-quality samplers and instruments to measure water level and velocity. Precipitation data was collected by use of a tipping-bucket raingage. Measurement, control, and storage of data were done by means of electronic dataloggers. Data were automatically retrieved twice daily using telephone modems. Descriptive statistics for stormwater runoff events from the SFD are detailed in appendixes $2-3$ and 2-4.

\section{Water-Quality Sampling and Analysis}

Water-quality samples were collected from the inlet, outlet, and bypass pipes of the SFD over 2.5 years. Station identification numbers and names for each sampling location are 430440089223500, MGE Stormwater Filter Inlet at Madison, Wis.; 430440089223400 MGE Stormwater Filter Outlet at Madison, Wis.; and 430440089223401, MGE Stormwater Filter Bypass at Madison, Wis.

Automatic samplers (fig. 5) were programmed to collect flow-weighted samples from the three pipes. The datalogger in the monitoring station was programmed to initiate a subsample for a predefined volume of flow; consequently, more subsamples were collected for large-volume runoff events than for small-volume runoff events. Flow-weighted sampling allowed for the collection of one composite sample for a stormwater runoff event, consisting of numerous subsamples collected throughout the course of the event. This approach resulted in a single flow-weighted or "event mean" concentration for each runoff event. The sample tubing of the inlet automatic sampler was installed $1 \mathrm{ft}$ upstream from where the flow entered the device, and the outlet sample line was installed $3 \mathrm{ft}$ downstream from where the flow exits the device. All sample lines were perpendicular to flow and approximately 1 inch from the bottom of the pipe. The bypass area-velocity flowmeter and sample tubing used to collect bypass stormwater were housed in separate pipes. Velocities were too high in the bypass pipe for the sampler to work properly, so the bypass sample tubing was placed $5 \mathrm{ft}$ upstream from the flow-splitter box.

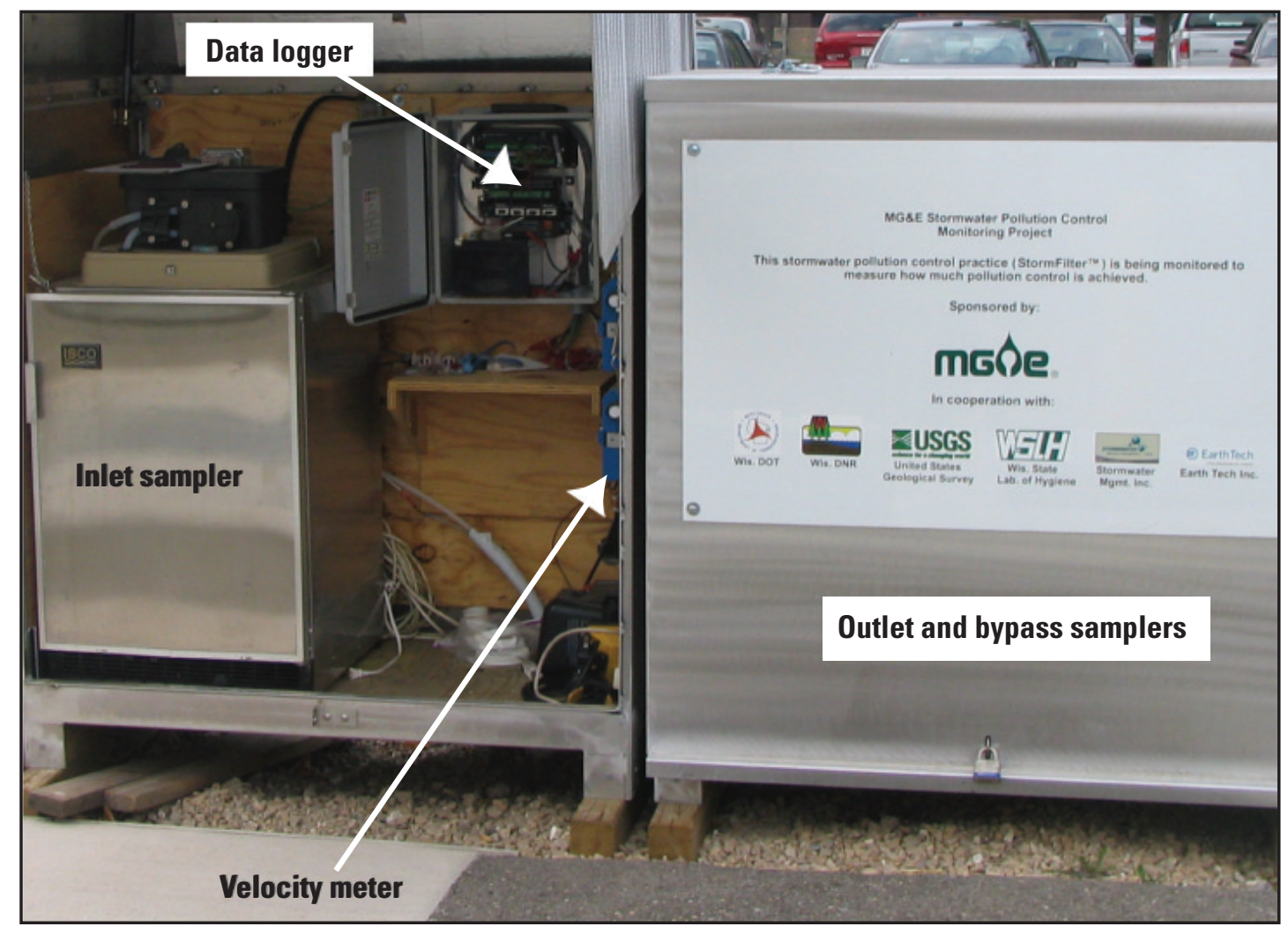

Figure 5. Automatic sampling equipment. 
The volume between subsamples was determined such that a minimum of five 1-L subsamples were collected for each event. The maximum sampler capacity was $401-\mathrm{L}$ subsamples. For events greater than or equal to 0.2 in. of precipitation and a minimum of five 1-L subsamples, the subsamples were processed for all constituents (tables 1 and 2); otherwise, subsamples were processed for concentrations of suspended sediment (SS), total suspended solids (TSS), and total dissolved solids (TDS). Samples were processed according to the churn-splitting procedure described by Horowitz and others (1997).

The constituents investigated were selected on the basis of the performance information from the manufacturer and the regulated constituents that the WisDOT might want to control in the future (tables 1 and 2). Samples were analyzed at the Wisconsin State Laboratory of Hygiene (SLOH), which participates in the USGS Standard Reference Sample (SRS) program (Woodworth and Connor, 2003).

\section{Precipitation}

A tipping-bucket raingage was used for continuous precipitation measurement. A datalogger recorded the number of bucket tips ( 0.09 in. per tip) every 60 seconds. This gage was not designed to record frozen precipitation, so data during periods of snowfall and freezing rainfall were not used. Calibration data showed there was no need to adjust precipitation data. All precipitation data collected for each site are listed in appendix 2-3. To accurately record precipitation amounts during varying intensities, a microprocessor in the raingage used a built-in polynomial to correct for the intensity, which was based on the tipping bucket's mechanism (Design Analysis Associates, 2001).

The raingage was attached to the back of the monitoring station. It was mounted on a 2 -in.-diameter pipe raised $10 \mathrm{ft}$ to avoid interference from nearby structures and to prevent vandalism. During two raingage calibrations, debris was cleaned from inside the raingage.

Table 1. Limits of detection and analytical methods for inorganic constituents analyzed in samples collected at the stormwater-filtration device, Madison, Wis.

[mg/L, milligrams per liter; P, phosphorus; $\mu \mathrm{g} / \mathrm{L}$ micrograms per liter; NA, not applicable]

\begin{tabular}{|c|c|c|c|c|}
\hline Constituent or characteristic & Unit & $\begin{array}{l}\text { Limit of } \\
\text { detection }\end{array}$ & $\begin{array}{c}\text { Limit of } \\
\text { quantification }{ }^{1}\end{array}$ & Method \\
\hline Dissolved solids, total & $\mathrm{mg} / \mathrm{L}$ & 50 & 167 & ${ }^{2} \mathrm{SM} 2540 \mathrm{C}$ \\
\hline Suspended solids, total & $\mathrm{mg} / \mathrm{L}$ & 2 & 7 & ${ }^{3} \mathrm{EPA} 160.2$ \\
\hline Volatile solids, total & $\mathrm{mg} / \mathrm{L}$ & 2 & 7 & ${ }^{3}$ EPA 160.2 \\
\hline Suspended sediment & $\mathrm{mg} / \mathrm{L}$ & 2 & 7 & ${ }^{2}$ ASTM D3977-97 \\
\hline Phosphorus, dissolved & $\mathrm{mg} / \mathrm{L}$ as $\mathrm{P}$ & .005 & .016 & ${ }^{3}$ EPA 365.1 \\
\hline Phosphorus, total & $\mathrm{mg} / \mathrm{L}$ as $\mathrm{P}$ & .005 & .016 & ${ }^{3}$ EPA 365.1 \\
\hline Chemical oxygen demand, total & $\mathrm{mg} / \mathrm{L}$ & 14 & 28 & ${ }^{3}$ EPA Method 410.4 \\
\hline Chemical oxygen demand, dissolved & $\mathrm{mg} / \mathrm{L}$ & 14 & 28 & ${ }^{3}$ EPA Method 410.4 \\
\hline Chloride, dissolved & $\mathrm{mg} / \mathrm{L}$ & .6 & 2 & ${ }^{2,1} \mathrm{SM} 4500 \mathrm{CL}$ \\
\hline Calcium, total recoverable & $\mathrm{mg} / \mathrm{L}$ & .02 & .07 & ${ }^{2}$ EPA 200.7 \\
\hline Magnesium, total recoverable & $\mathrm{mg} / \mathrm{L}$ & .03 & .7 & ${ }^{2} \mathrm{EPA} 200.7$ \\
\hline Zinc, dissolved & $\mu \mathrm{g} / \mathrm{L}$ & 16 & 50 & ${ }^{2}$ EPA 200.9 \\
\hline Zinc, total recoverable & $\mu \mathrm{g} / \mathrm{L}$ & 16 & 50 & ${ }^{2,1}$ EPA 200.9 \\
\hline Copper, dissolved & $\mu \mathrm{g} / \mathrm{L}$ & 1 & 3 & ${ }^{2} \mathrm{SM} 3113 \mathrm{~B}$ \\
\hline Copper, total recoverable & $\mu \mathrm{g} / \mathrm{L}$ & 1 & 3 & ${ }^{2} \mathrm{SM} 3113 \mathrm{~B}$ \\
\hline Wet-sieve of sediment & NA & NA & NA & ${ }^{4}$ Burton \\
\hline Coulter counter of sediment & NA & NA & NA & ${ }^{4}$ Burton \\
\hline Laser diffraction of sediment & NA & NA & NA & ${ }^{4}$ Burton \\
\hline Microfiltration of sediment & NA & NA & NA & ${ }^{4}$ Burton \\
\hline
\end{tabular}


Table 2. Limits of detection and analytical methods for polycyclic aromatic hydrocarbons analyzed in samples collected at the stormwater-filtration device, Madison, Wis.

[All data in micrograms per liter, determined by use of method SW8310 in American Public Health Association and others, 1989']

\begin{tabular}{lcc}
\hline Constituent or characteristic & $\begin{array}{c}\text { Limit of } \\
\text { detection }\end{array}$ & $\begin{array}{c}\text { Limit of } \\
\text { quantification }\end{array}$ \\
\hline 1-Methylnaphthalene & 0.064 & 0.2 \\
2-Methylnaphthalene & .049 & .16 \\
Fluorene & .52 & 1.7 \\
Acenaphthene & .064 & .20 \\
Acenaphthylene & .11 & .34 \\
Anthracene & .031 & .1 \\
Benzo[a]anthracene & .093 & .30 \\
Benzo[a]pyrene & .16 & .52 \\
Benzo[b]fluoranthene & .13 & .41 \\
Benzo[g,h,i]perylene & .14 & .44 \\
Benzo[k]fluoranthene & .12 & .38 \\
Chrysene & .027 & .09 \\
Dibenzo[a,h]anthracene & .034 & .11 \\
Fluoranthene & .11 & .35 \\
Indeno[1,2,3-cd]pyrene & .093 & .30 \\
Phenanthrene & .093 & .30 \\
Pyrene & .11 & .34 \\
Naphthalene & .042 & .13 \\
\hline
\end{tabular}

${ }^{1}$ American Public Health Association and others, 1989; SM (Standard Methods).

${ }^{2}$ Limit of quantification is the low standard in the calibration curve.

\section{Flow Monitoring}

Area-velocity flowmeters were installed that use continuous-wave Doppler technology to measure average velocity. The sensor transmits a continuous ultrasonic wave and then measures the frequency shift of returned echoes reflected by air bubbles or particles in the flow (Teledyne Isco, 2004). Three meters were installed to monitor flow in the 6-in.-diameter inlet pipe, 6-in.-diameter outlet pipe, and 15-in.-diameter bypass pipe. The area-velocity flowmeters at the inlet and outlet were installed 4 in. downstream from the sample intake tubes.

Because laminar flow was necessary to produce accurate measurements from the area-velocity meter, an additional $3-\mathrm{ft}$ length of pipe was attached to the inlet pipe (fig. 6). The outlet area-velocity flowmeter was $3 \mathrm{ft}$ downstream from the device in a 6-in.-diameter pipe. The area-velocity meter was placed downstream from the external bypass weir in a 15 -in.-diameter pipe that graded at a 29-percent slope.

A stand-alone stage pressure transducer and temperature probe were installed in May 2006. The transducer and probe were installed $2 \mathrm{ft}$ in front of the SFD internal bypass weir

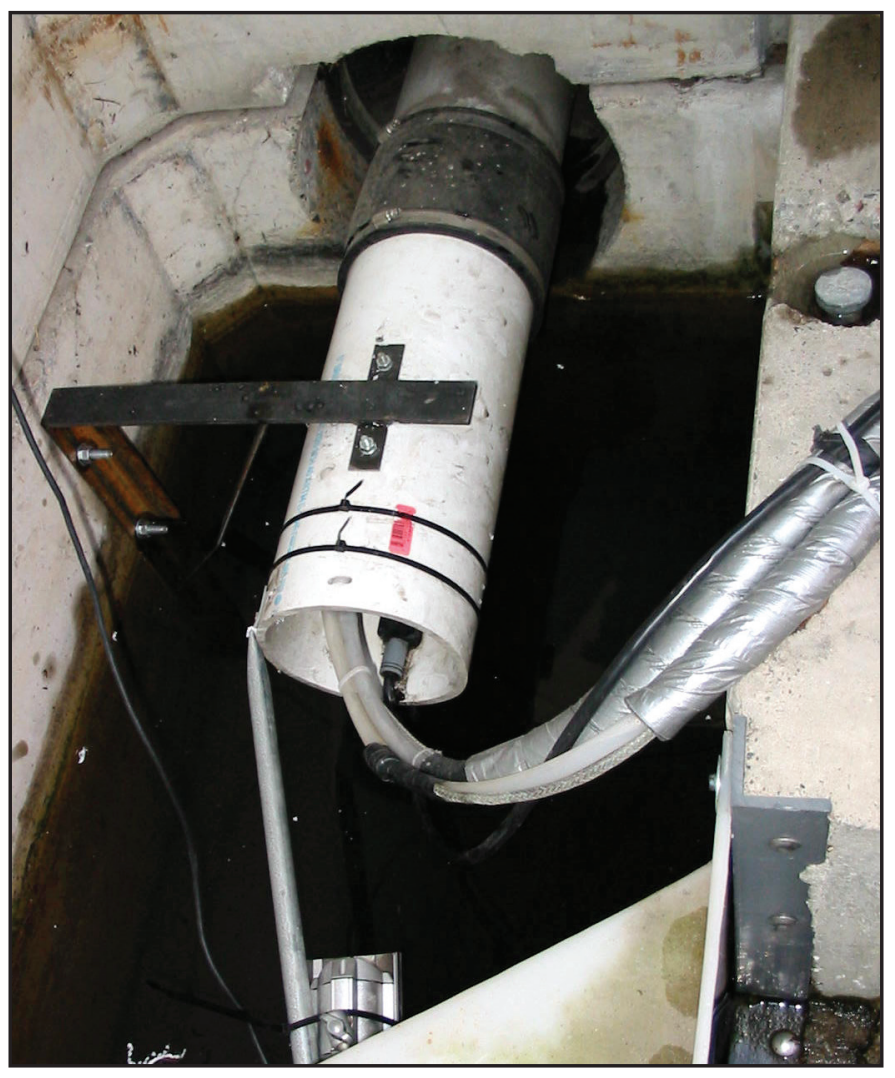

Figure 6. Inlet pipe with stabilization bar.

(fig. 4). The recorded depth indicated the height of flow in the filtration bay.

Cameras were installed at five locations to identify problems with sampling equipment or to detect a change in flow regimen at (1) the flow-splitter box to detect bypass flows, (2) the inlet pipe to detect debris on the meter, (3) the pressure transducer and device weir to detect overflows, (4) the bypass pipe to detect movement of the meter, and (5) the exit manhole, where the bypass pipe and the device outlet pipe flow, to detect back-water flow. Digital recordings were controlled by an inlet stage threshold that turned the cameras on and off.

\section{Calibration of Gage Height}

Corrections were applied to stage measurements (for June 22, 2005; July 13, 2006; and June 11, 2007) that reflect differences between water-surface elevations measured manually and those measured with the area-velocity flowmeters. To generate two sets of elevations for comparison, the meters were placed in separate buckets. Water levels then were increased in each bucket, and measurements were made at various levels, representing the entire depth of the pipe. Ten to 15 readings were taken at each meter. Results from this procedure were used to make stage corrections throughout the entire monitored period of record (November 2005-August 2007). Accuracy of the records, on average, was estimated to be within \pm 2 percent. 


\section{Calibration of Flow}

Stormwater runoff was measured at the inlet, outlet, and bypass pipes of the SFD. A dye-dilution system was installed to calibrate flow rate at the inlet. The outlet meter was corrected using the calibrated inlet flows. It was not necessary to correct bypass flows because no bypass event samples were processed.

\section{Inlet Flows}

In October 2006, an automatic dye-dilution system was installed to calibrate flow. A separate gage house for sampling dye, fluorometer, and datalogger to record dye-dilution data was located adjacent to the sampling gage houses. The injection site for known dye concentrations was $20 \mathrm{ft}$ upstream from the inlet area-velocity flowmeter (fig. 6). A dye-sampling tube was placed $1 \mathrm{in}$. downstream from the inlet-sampling tube for a uniform mixture of stormwater and dye. The mixture was pumped to the fluorometer to measure the concentration of dye fluorescence. A dye dilution occurred when a given stage threshold was reached at the inlet area-velocity flowmeter. is

The equation used to convert dye measurements to flow

$$
Q=q \times C / c,
$$

where

$$
\begin{aligned}
& Q \quad \text { is flow being measured, in cubic feet, } \\
& q \text { is injection rate, in milliliters per minute, } \\
& C \text { is concentration of injected dye, in percent } \\
& \text { by volume, and } \\
& c \text { is concentration of measure, in micrograms } \\
& \text { per liter. }
\end{aligned}
$$

In 2007, more than 200 sample points were recorded for calibration at the inlet meter from six events (April 25, May 15, July 3 and 26, and August 4 and 5). Comparison of the data points from the inlet area-velocity meter and the dyedilution flow indicated that the inlet area-velocity meter was reading low by an average of 18 percent (fig. 7). To correct the inlet flow measurements, a plot of dye-to-metered-flow data points was used to produce a correction equation with an $\mathrm{R}^{2}=0.9825$ :

Inlet corrected flow $=1.5689 *($ Inlet flow measured $)-0.0469$

\section{Outlet Flows}

It was not possible to calibrate the outlet area-velocity meter owing to the short mixing zone between the flow exiting the cartridge bay and the outlet area-velocity meter. Because there was no external bypass through the filtration device for most events, the outlet meter could be corrected using the inlet-corrected event volumes.

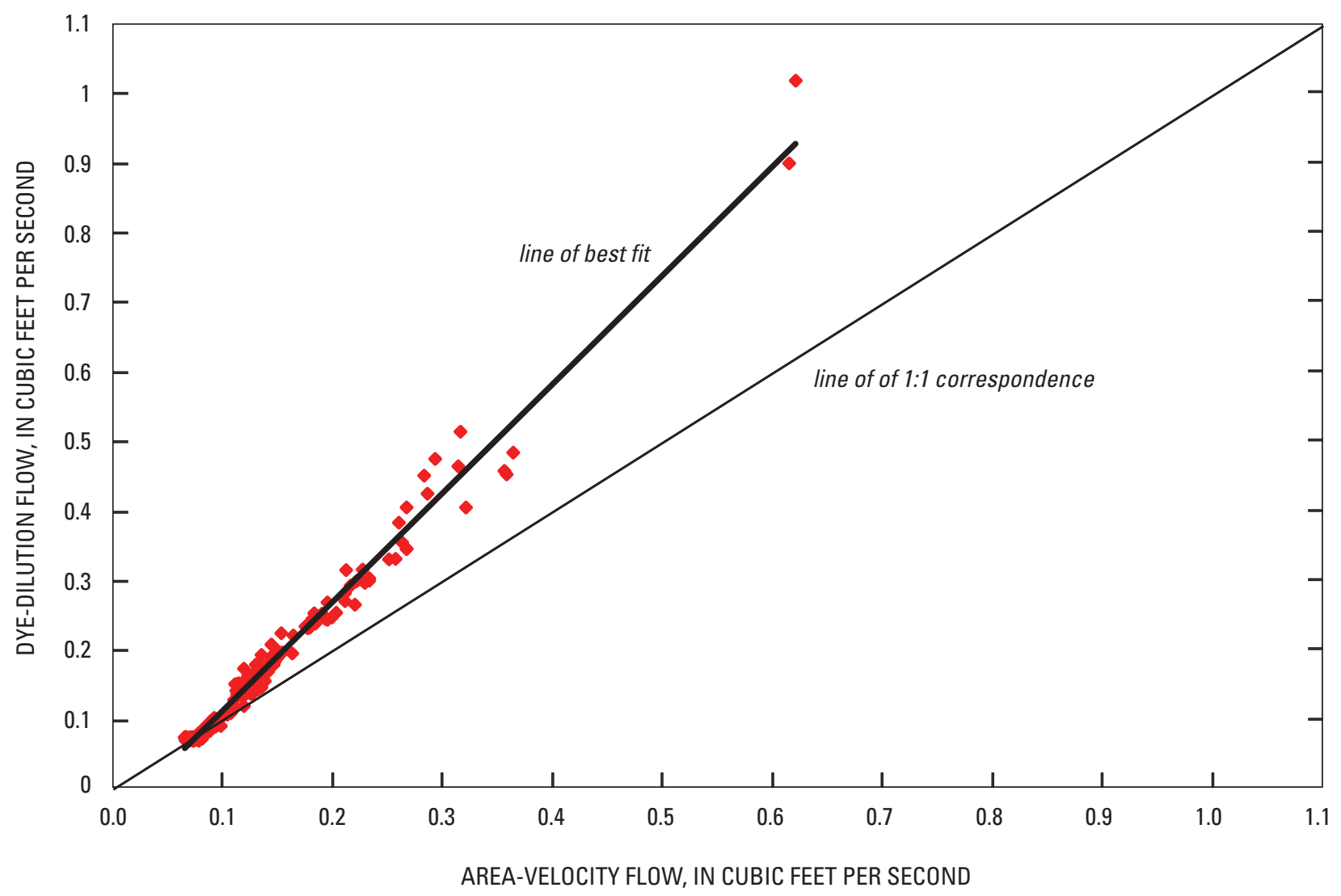

Figure 7. Dye-dilution flow in relation to area-velocity flow at the inlet of the stormwater-filtration device. 


\section{Monitoring Complications}

Bypass meter. The external bypass flow exited through a 15-in.-diameter PVC pipe that was set at a 29-percent slope. The area-velocity meter was attached to a spring band and placed $3 \mathrm{ft}$ upstream from the exit manhole. During a runoff event on August 25, 2005, the high velocities of runoff forced the meter downstream. Subsequently, screws were used to secure the spring band. On August 21, 2006, the probe of the area-velocity meter was replaced because the unit was recording negative values.

High-flow weirs. The SFD was designed with external and internal high-flow bypass weirs. During JulyOctober 2005, stormwater runoff was measured for 16 events; 8 of the events produced external bypassing, and 4 produced internal bypassing. The manufacturer decided that additional stormwater could be passed to the filter by increasing the heights of both weir plates. The task of increasing the heights of the weir plates was completed on November 1, 2005. This adjustment reduced the number of bypasses to three during the rest of the study period.

Datalogger. Programming changes between the datalogger and the velocity meter were added that omitted data spikes during non-events. Communications from the area-velocity meter to the datalogger were managed through serial string translation. During non-events, data were recorded for the first minute of the hour. When particles were not available for the area-velocity meter, the meter could not correctly determine the velocity within that minute; therefore, the datalogger translated the velocity data as an extremely high or low data point. To replace the high or low data point with the last valid velocity recorded by the area-velocity meter, high and low cutoff thresholds were programmed into the datalogger. To validate removal of these high or low data points, the velocity data recorded by the datalogger were compared to velocity data recorded by the internal memory of the area-velocity meter. The area-velocity meter stores 15 -second data for approximately 2 days, then overwrites it with new data. Programming changes were made in April 2006.

Dye-dilution system. From October through December 2006, four dye-dilution events were recorded (fig. 8). These data were not used because the ratios of dye dilution to areavelocity flow were inconsistent. Review of the video revealed that the stage-flow relation was distorted by large volumes of stormwater that shifted the extended inlet pipe downward. To correct this problem, a stabilization bar was attached from the SFD wall to the extended inlet pipe (fig. 6). The stabilization bar was added on April 29, 2007. Because of the shifting of the inlet pipe during large-volume events, there were probably some errors in the data collected before the inlet pipe was stabilized. Also, during one runoff event, debris became draped over the meter.

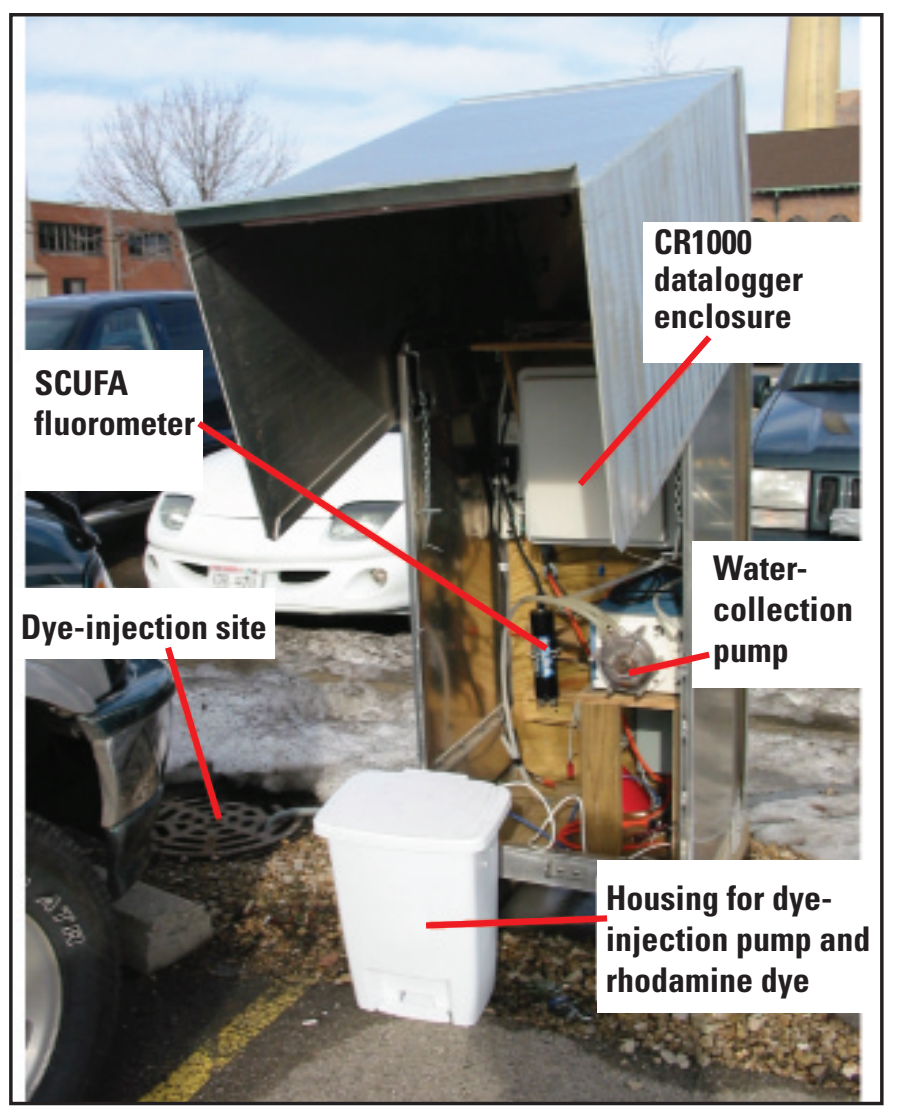

Figure 8. Dye-dilution equipment.

\section{Quality Control}

The field-equipment blank and replicate samples were collected at the inlet and outlet of the SFD and analyzed for the same constituents as those for runoff samples (appendix 2-1). The equipment blank procedure passed deionized water through the sampler and processed through the churn to validate clean sampling procedures (Wilde, 2006). Blanks were collected at the beginning and midpoint of the project to validate clean-sampling procedures.

Three equipment blank samples were collected to validate clean-sampling procedures: the first was collected before sampling began (blank 1), the second between events 18 and 19 (blank 2) and the third between events 40 and 41 (blank 3). Blank 1 contained detectable concentrations of dissolved copper $(\mathrm{DCu})$ and total copper $(\mathrm{TCu})$, but these concentrations were below the limit of quantification (LOQ) for the inlet and outlet. Blank 2 had detectable concentrations of total phosphorus (TP) and dissolved phosphorus (DP) from the inlet, outlet, and bypass, and dissolved zinc (DZn) from the outlet, but all concentrations were below LOQ. In blank 2, from the outlet, the concentration of DCu exceeded the LOQ. Quality-control samples collected directly from the sampler and from the jar of blank water were analyzed, but analyses resulted in no detects (appendix 2-1). Blank 3 had no detectable concentrations. 
Replicate samples were collected during several stormwater events to quantify the variability or precision of sampling procedures. Analytical precision was a measurement of how much an individual measurement deviates from a mean of replicate measurements. The relative percent difference (RPD) was calculated to evaluate precision in procedures after sample collection.

The relative percent difference equation is

$$
\% R P D=\left[\left(X_{1}-X_{2}\right) / \bar{X}\right] \times 100,
$$

where

$$
\begin{gathered}
X_{1} \text { is concentration of constituent in a sample, } \\
X_{2} \text { is concentration of a constituent in a duplicate } \\
\bar{X} \quad \text { sample, and } \\
\text { is mean value of } X_{1} \text { and } X_{2} .
\end{gathered}
$$

Replicate samples were collected during events 1, 9, 23, and 44 to quantify variability in the sampling process. The RPD target for TSS was 30 percent or less; for recoverable metals, the RPD target was 25 percent or less (appendix 2-2). In replicates for event 9 the RPD target of 25 percent was exceeded for total zinc (TZn), and for event 23 the RPD target of 25 was exceeded for TCu. For all of the dissolved constituents, a relatively low RPD was reported, but RPDs that were greater than the target were reported for some of the particulate constituents.

\section{Processing of Water-Quality Samples}

A new procedure was used to improve the accuracy and precision of measured quantity of particulate constituents in samples that contained a large amount of sand-sized particles $(>125 \mu \mathrm{m})$. Previous studies have shown that using a churn to partition samples with large quantities of sand had the potential to cause a positive bias and to lower the precision of constituent concentrations associated with particulates (Horowitz and others, 1997). The use of a wet-sieving process decreased these errors for sediment-associated constituent concentrations (Selbig and others, 2007). This process consisted of pouring a known quantity of sample through sieves of $125 \mu \mathrm{m}, 250 \mu \mathrm{m}$, and $500 \mu \mathrm{m}$ before churning the aqueous portion. Material collected on sieves was sent to the SLOH in individual bottles to be dried and weighed. Dried material from each of the sieves was then combined and processed for total recoverable metals and phosphorus. This process was used for six events, which were determined by stirring the samples and observing at least $2 \mathrm{~g}$ of material at the bottom of the bottle after 1 minute. For samples from these six events, large amounts of material dropped to the bottom of the glass jar within 1 minute of stirring the sample. The aqueous portion of the sample that passed through the sieves was processed using typical USGS churning procedures (Horowitz and others, 1997). All concentrations of SS presented in this report include sieved material.
Sample results of the sieved mass were added back to the aqueous portion to determine a mean concentration for the event by using the following equation (Selbig and others, 2007):

$$
C_{I}=((S m / 1000) \times C s) / V,
$$

where

$C_{I} \quad$ is concentration of sieved solids, in $\mathrm{mg} / \mathrm{L}$,

$\mathrm{Sm}$ is mass of sieved solids after drying, in grams, Cs is concentration of sieved solid, in $\mathrm{mg} / \mathrm{kg}$, and $V \quad$ is volume of sieved water, in liters.

\section{Particle-Size Analysis}

In July 2004, the USGS Wisconsin Water Science Center adopted a new method for particle-size analysis. Previous methods required a large sample volume to provide enough sediment for analysis. Previous methods were not designed for the relatively low levels of sediment observed in stormwater samples. The new method requires only about a liter of sample and has been incorporated into this project. The new particlesize analysis uses a two-step process developed by the SLOH.

The first step was to wet sieve the sample for the particle sizes of $500,250,125,63$, and $32 \mu \mathrm{m}$. The material on the sieves was then dried and weighed. The second step was to separate the particles less than $32 \mu \mathrm{m}$ into particle-size fractions of $16,8,4$, and $2 \mu \mathrm{m}$. For the first 30 samples a laser counter was used to identify the quantity of the four smaller particle sizes. For later samples a Coulter counter (Beckman Coulter Multisizer 3 particle-size counter; Graham, 2003) was used to determine the quantity of smaller particles. Other researchers have used a Coulter counter to evaluate particle sizes in stormwater (Burton and Pitt, 2002). The Coulter counter was calibrated by microfiltering replicate samples with polycarbonate filters.

\section{Treatment Efficiency of the Stormwater-Filtration Device}

Rainfall, flow, particle-size, and water-quality data were important in evaluating the effectiveness of the filtration device. A comparison of monitored event rainfall depths and long-term trends in rainfall depths helped evaluate if the monitoring data were representative of rainfall patterns in Madison. The flow data were needed to determine the volumes of runoff entering and leaving the filtration device. Efficiencies of the SFD were evaluated by first determining if the inlet and outlet concentrations were significantly different. For those that were significantly different, the concentrations and loads were used to determine efficiency ratios and sum of the loads. 


\section{Precipitation Data}

Precipitation data collected at the site were compared to National Oceanic and Atmospheric Administration (NOAA) data collected at the Dane County Regional Airport (DCRA). Precipitation data collected by both gages were comparable to the long-term average at DCRA (table 3). DCRA was approximately 4 mi northeast of the SFD.

Table 3. Monthly precipitation at the U.S. Geological Survey raingage and the National Oceanic and Atmospheric Administration precipitation gage at the Dane County Regional Airport, Madison, Wis., 2005-07.

[Precipitation is presented in inches; USGS, U.S. Geological Survey; NOAA, National Oceanic and Atmospheric Administration; DCRA, Dane County Regional Airport; --, no data]

\begin{tabular}{|c|c|c|c|}
\hline Month & $\begin{array}{c}\text { USGS } \\
\text { precipitation }\end{array}$ & $\begin{array}{l}\text { NOAA } \\
\text { hourly } \\
\text { DCRA }\end{array}$ & $\begin{array}{c}\text { NOAA } \\
\text { DCRA } \\
\text { Iong-term } \\
\text { average }\end{array}$ \\
\hline July 2005 & 2.5 & 3.9 & 3.9 \\
\hline August 2005 & 1.5 & 1.2 & 4.3 \\
\hline September 2005 & 2.1 & 2.0 & 3.1 \\
\hline October 2005 & .6 & .76 & 2.2 \\
\hline November 2005 & 3.2 & 3.4 & 2.3 \\
\hline December 2005 & -- & -- & -- \\
\hline Partial year total 2005 & 9.9 & 11.3 & 15.8 \\
\hline January 2006 & -- & -- & -- \\
\hline February 2006 & -- & -- & -- \\
\hline March 2006 & 2.0 & 2.3 & 2.3 \\
\hline April 2006 & 6.2 & 4.2 & 3.4 \\
\hline May 2006 & 4.4 & 4.6 & 3.2 \\
\hline June 2006 & 3.0 & 2.3 & 4.0 \\
\hline July 2006 & 7.0 & 4.2 & 3.9 \\
\hline August 2006 & 5.7 & 5.4 & 4.3 \\
\hline September 2006 & 3.2 & 3.3 & 3.1 \\
\hline October 2006 & 2.1 & 2.2 & 2.9 \\
\hline November 2006 & 2.2 & 2.3 & 2.3 \\
\hline December 2006 & 1.2 & 1.7 & 1.7 \\
\hline Partial year total 2006 & 37.0 & 32.5 & 31.1 \\
\hline January 2007 & -- & -- & -- \\
\hline February 2007 & -- & -- & -- \\
\hline March 2007 & 2.5 & 3.4 & 2.3 \\
\hline April 2007 & 3.7 & 4.7 & 3.4 \\
\hline May 2007 & 1.5 & 1.4 & 3.2 \\
\hline June 2007 & 3.9 & 4.8 & 4.0 \\
\hline July 2007 & 1.2 & 2.7 & 3.9 \\
\hline August 2007 & 12.9 & 15.1 & 4.3 \\
\hline Partial year total 2007 & 25.7 & 32.1 & 21.1 \\
\hline
\end{tabular}

${ }^{1}$ Average for 1971 to 2000 data for Dane County Regional Airport, Wis.
The difference between the total from the USGS (onsite) precipitation data and the 2005-07 totals from the DCRA precipitation data was less than 20 percent. Larger differences generally occurred during the summer months when precipitation amounts can vary substantially over distances as small as $4 \mathrm{mi}$, owing to a predominance of localized convective events. For precipitation in 2005, the USGS precipitation data recorded was $5.9 \mathrm{in}$. less than the long-term average at DCRA, whereas in 2006 and 2007, the USGS precipitation averages were 5.9 and 4.6 in. higher, respectively, than the long-term average at DCRA.

Because flow rates can affect the performance of a stormwater-control practice, a project determining the treatment efficiency of a practice would benefit by sampling a mix of precipitation depths and intensities. Ideally, the distribution of precipitation depths for a project would be comparable to the long-term distribution of precipitation depths. It would not be a valid test of a treatment device if the sampled events favored either all small or all large precipitation depths for the observed area (Bachhuber and others, 2001). To assess how the mix of precipitation events during the project period compared to long-term precipitation patterns, the distribution of monitored precipitation depths from this study was compared to the historical distribution of precipitation depths from the NOAA DCRA site (1997).

Probability distributions for both data sets were constructed by use of the Weibull plotting position (Helsel and Hirsch, 1992). Precipitation amounts for individual events were computed for both data sets. Precipitation greater than or equal to $0.19 \mathrm{in}$. (the minimum amount recorded during this project) were ranked from lowest to highest. A cumulative probability distribution then was computed for both data sets by use of the formula

$$
P_{R}=i_{R} /(n+1),
$$

where

$$
\begin{array}{cl}
R & \text { is precipitation event, } \\
P_{R} & \text { is probability of an event having a } \\
& \text { precipitation less than that of event, } \\
i_{R} & \text { is ranking of event } R, \text { and } \\
n & \text { is total number of events in the data set. }
\end{array}
$$

Although the distribution for this study tends to be a little higher than the historical distribution, the distribution for this study would still be considered very similar to the historical distribution (fig. 9). 


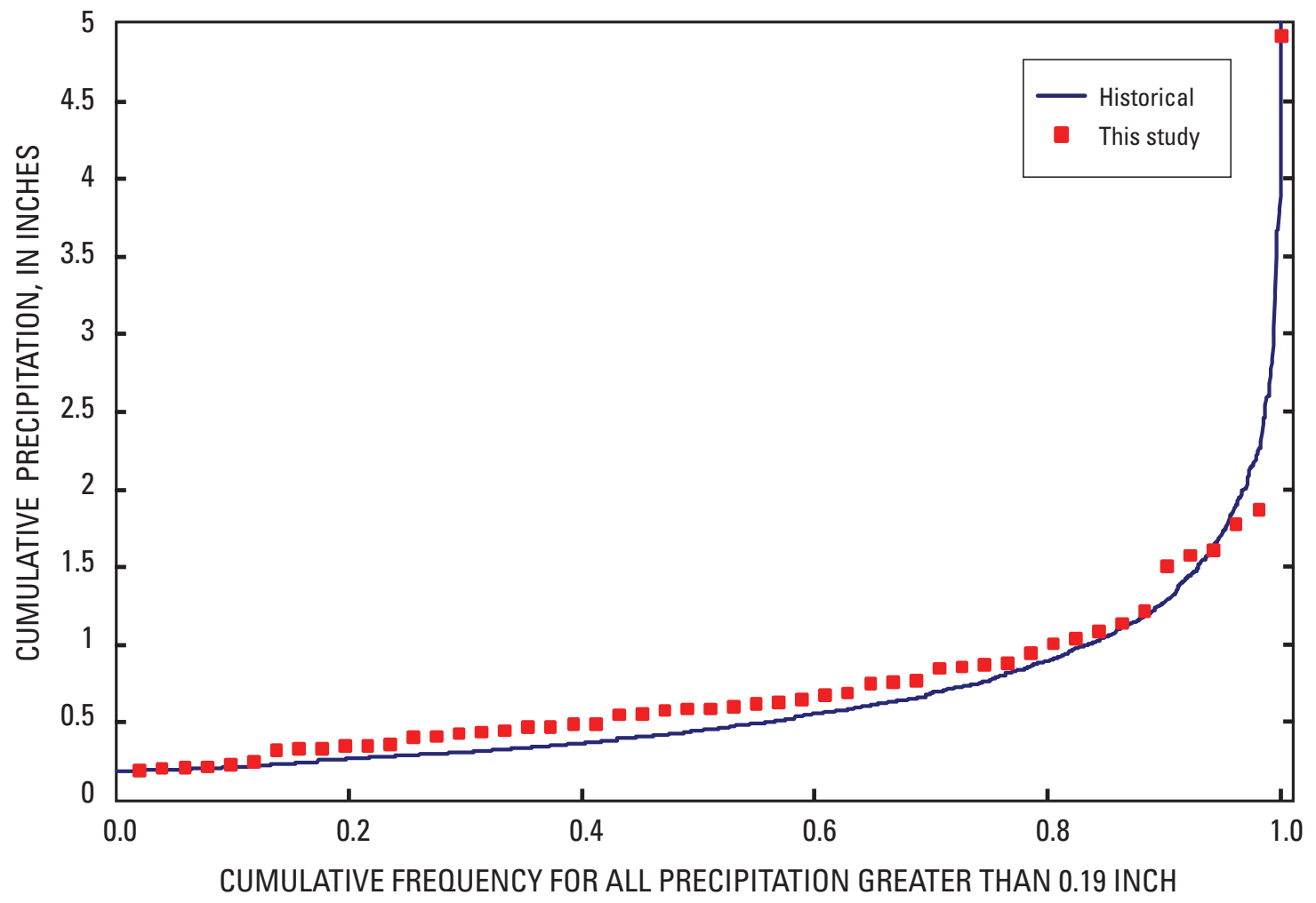

Figure 9. Cumulative precipitation for the study period (2005-07) in relation to the cumulative frequency for all precipitation greater than 0.19 inches (1949-92) based on the National Oceanic and Atmospheric Administration precipitation gage at Dane County Regional Airport, Madison, Wis.

\section{Stormwater-Flow Data}

Volumes of stormwater measured at the outlet ideally were the same as volumes at the inlet because there was no external bypassing after the flows entered the SFD. To verify that the outlet area-velocity flowmeter was recording flow correctly, volumes from the outlet were compared to corrected inlet volumes (fig. 10). Only 2007 event volumes were used for the comparison, because the inlet meter produced some inconsistencies in the stage-flow relation before the inlet pipe was secured. On average the outlet volumes were 5 percent lower than the inlet volumes, so no correction was applied to the outlet. Flows for the outlet were not affected by a shifting pipe in 2005 and 2006, so the outlet flows were used to calculate event volumes.

\section{Number of Events with Water-Quality Data}

From November 5, 2005, until August 18, 2007, 51 runoff events were monitored for water quality and water quantity. The precipitation for these sampled events ranged from 0.19 to 4.93 in. (appendix 2-3). The maximum 15- and 60-minute precipitation intensities were 7.01 and $3.79 \mathrm{in} / \mathrm{hr}$, respectively. For the drainage area without gravel islands, the precipitation volumes ranged from 250 to
$15,210 \mathrm{ft}^{3}$. The volume of stormwater that passed through the filtration system ranged from 235 to $8,210 \mathrm{ft}^{3}$ (appendix 2-4). On average, 63 percent of the precipitation resulted in direct runoff from the site. There were two events during which stormwater bypassed the SFD after heights of the weirs were increased, but data from those events are not included in the report. For one event, flow at the inlet, outlet, and bypass were poorly sampled. For the second, only one sample was collected; therefore, bypassing events are not included in the report.

\section{Particle-Size Distributions}

Sufficient sample volume was available to do particlesize analysis for 36 events (appendix 2-8). The particle-size distributions (PSD) at the inlet and outlet varied for each event. For the inlet samples the portion of silt- and clay-sized particles $(<63 \mu \mathrm{m})$ ranged from 29 to 80 percent. A similar range occurred for the outlet samples; the portion of silt- and clay-sized particles ranged from 33 to 94 percent. On the basis of average particle sizes for all events, slightly more silt- and clay-sized particles were present in the inlet water than sandsized particles (table 4). At the Milwaukee SFD site, silt- and clay-sized particles averaged only 20 percent of the sediment (U.S. Environmental Protection Agency, 2004). 


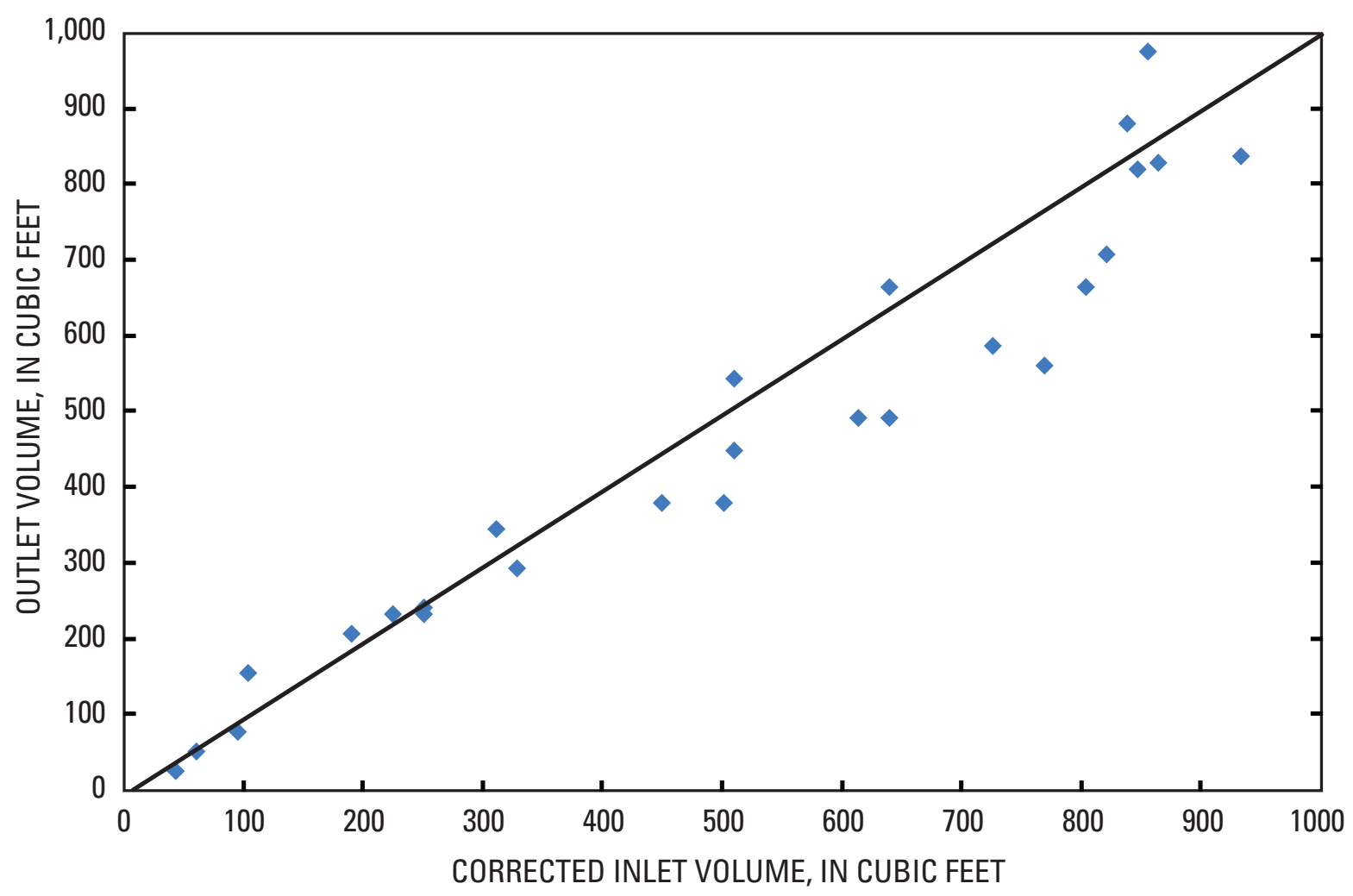

Figure 10. Stormwater volumes at the inlet of the stormwater-filtration device corrected by dye dilution in relation to outlet volumes, Madison, Wis., 2007.

Table 4. Average particle-size distribution in stormwater samples collected from the inlet and outlet of a stormwater-filtration device, Madison, Wis.

[All data are in percent by mass; $\mu \mathrm{m}$, micrometer]

\begin{tabular}{lccccccccc}
\hline \multirow{2}{*}{$\begin{array}{l}\text { Sampling } \\
\text { location }\end{array}$} & $\mathbf{5 0 0} \boldsymbol{\mu \mathbf { m }}$ & $\mathbf{2 5 0} \boldsymbol{\mu \mathbf { m }}$ & $\mathbf{1 2 5} \boldsymbol{\mu \mathbf { m }}$ & $\mathbf{6 3} \mathbf{\mu \mathbf { m }}$ & $\mathbf{3 1} \mathbf{\mu \mathbf { m }}$ & $\mathbf{1 6} \boldsymbol{\mu \mathbf { m }}$ & $\mathbf{8} \boldsymbol{\mu \mathbf { m }}$ & $\mathbf{4} \boldsymbol{\mu \mathbf { m }}$ & $\mathbf{2} \boldsymbol{\mu \mathbf { m }}$ \\
\hline Inlet & 90 & 81 & 71 & 57 & 43 & 36 & 31 & 27 & 17 \\
Outlet & 94 & 87 & 82 & 68 & 54 & 47 & 41 & 35 & 24 \\
\hline
\end{tabular}

Outlet flows contained a greater percentage of fine particles than the inlet flows. There was a shift to a larger percentage of the smaller particles because the larger particles were trapped in the SFD. The average percentage of particles less than $63 \mu \mathrm{m}$ increased from 57 percent at the inlet to 68 percent at the outlet (table 4).

In previous studies of stormwater-control practices, particle-size distribution had some effect on the reduction of TSS and SS achieved by the device (Waschbusch, 1999; Horwatich and others, 2004). The average distribution of particles at the inlet indicated about a 20-percent reduction in concentrations of TSS and SS was possible by controlling all the particles greater than 250 microns. About a 40- and an 80-percent reduction might be possible by trapping all the particles greater than 63 and $4 \mu \mathrm{m}$, respectively. The average particle-size distribution is necessary to enter in some models, such as WinSLAMM, which is designed to predict the TSS reduction in stormwater-control devices. A PSD for each transportation facility appears to be a necessary input to determine device efficiency in such models.

\section{Water-Quality Data for the Inlet and Outlet}

Constituent concentrations for each stormwater event are listed in appendix 2 (appendixes 2-5 through 2-7). Thirtythree constituents were analyzed for the inlet and outlet samples. Eighteen of the constituents were individual PAH compounds. Samples from 31 runoff events were analyzed for all constituents except PAHs. Samples from 15 stormwater events were analyzed for PAHs. 
Non-detectable compounds composed a substantial proportion of the total PAH results. Non-detectable compounds were below detection limits for samples from the outlet more often than samples from the inlet. To calculate summary statistics for individual PAH compounds that had non-detects less than 80 percent, the Kaplan-Meier analysis was used (Helsel, 2004). Non-detectable compounds that were greater than 80 percent detection were the following 7 of the 18 PAHs: 1-methylnaphthalene, 2-methylnaphthalene, acenaphthylene, acenaphthene, fluorene, dibenzo[a,h]anthracene, naphthalene; summary statistics were not computed for these compounds. To calculate the summary statistics for total PAHs, a method was needed to account for the non-detected concentrations. Methods included using the limit of detections, one-half the limit of detections, and zero. To be consistent with other USGS studies, the total PAH concentrations were calculated by using zero (Mahler and others, 2005).
Constituent concentrations followed a log-normal distribution from inlet and outlet samples. The Shapiro-Wilk statistic was used to test for normality (Helsel and Hirsch, 1992). Runoff data from many urban sites around the country exhibited similar distributions for event-mean concentrations; these concentrations were either log-normal or could be approximated as log-normally distributed (Driscoll and others, 1990). Data sets that were log-normally distributed are better estimated by the median because it reduces the influence of a few extreme observations. The mean concentrations are also reported because they are used to calculate the efficiency ratio. These are typical reporting methods used to determine removal efficiencies for urban stormwater best-management practices (Strecker and others, 2003). The minimums, maximums, medians, and means for all the constituents are presented in table 5, and the statistics for individual PAHs are presented in table 6 .

Table 5. Summary statistics for selected water-quality constituents in samples collected from a stormwater-filtration device, Madison, Wis.

$[\mathrm{mg} / \mathrm{L}$, milligrams per liter; <, less than; ( ), number of nondetects; \{\} , without total suspended solids for runoff event 12 and total phosphorus for runoff event 8 - concentrations for these events appeared to be in error; --, not computed; $\mu \mathrm{g} / \mathrm{L}$ micrograms per liter; PAHs, polycyclic aromatic hydrocarbons]

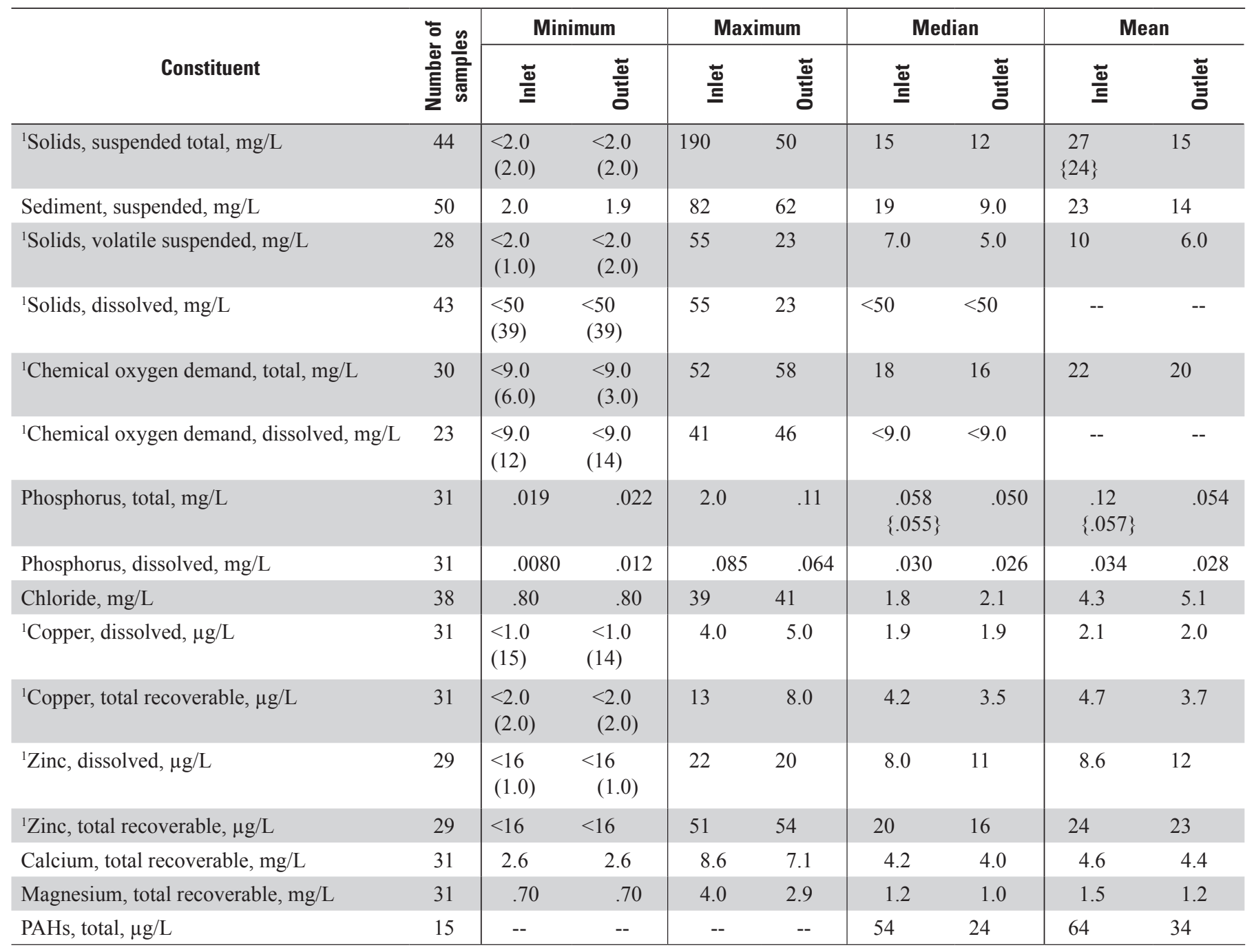

${ }^{1}$ Kaplan-Meier analysis for non-detects was used to calculate summary statistics (Helsel, 2005). 
Table 6. Summary statistics for individual polycyclic aromatic hydrocarbons in 15 samples collected from a stormwaterfiltration device, Madison, Wis.

[All constituents in micrograms per liter; <, less than; --, not computed]

\begin{tabular}{|c|c|c|c|c|c|c|c|c|c|c|}
\hline \multirow{2}{*}{ Constituent } & \multicolumn{2}{|c|}{$\begin{array}{c}\text { Number of } \\
\text { non-detects }\end{array}$} & \multicolumn{2}{|c|}{ Minimum } & \multicolumn{2}{|c|}{ Maximum } & \multicolumn{2}{|c|}{ Median } & \multicolumn{2}{|c|}{ Mean } \\
\hline & Inlet & Outlet & Inlet & Outlet & Inlet & Outlet & Inlet & Outlet & Inlet & Outlet \\
\hline 2-Methylnaphthalene & 11 & 13 & $<0.049$ & $<0.049$ & 0.11 & 0.12 & -- & -- & -- & -- \\
\hline 1-Methylnaphthalene & 15 & 15 & $<.064$ & $<.064$ & $<.64$ & $<.20$ & -- & -- & -- & -- \\
\hline Acenaphthylene & 15 & 15 & $<.11$ & $<.11$ & $<1.1$ & $<.33$ & -- & -- & -- & -- \\
\hline Acenaphthene & 9 & 13 & $<.064$ & $<.064$ & .17 & .24 & -- & -- & -- & -- \\
\hline Anthracene ${ }^{1}$ & 1 & 4 & .052 & $<.031$ & .97 & .49 & 0.25 & 0.074 & 0.27 & 0.13 \\
\hline Benzo[b]fluoranthene & 0 & 0 & 1.7 & .91 & 18 & 11 & 5.2 & 2.7 & 6.4 & 3.8 \\
\hline Benzo[k]fluoranthene & 0 & 0 & .68 & .36 & 8.2 & 4.8 & 2.4 & 1.1 & 2.9 & 1.6 \\
\hline Benzo[a]pyrene & 0 & 0 & .66 & .33 & 12 & 6.4 & 3.6 & 1.1 & 3.7 & 1.9 \\
\hline Chrysene & 0 & 0 & 1.4 & .62 & 17 & 9.5 & 4.7 & 2.3 & 5.7 & 3.1 \\
\hline Fluoranthene & 0 & 0 & 3.7 & 1.6 & 47 & 25 & 13 & 5.9 & 16 & 3.3 \\
\hline 9H-Fluorene & 15 & 15 & $<.52$ & $<.52$ & $<.52$ & $<.52$ & -- & -- & -- & -- \\
\hline Indeno[1,2,3-cd]pyrene & 0 & 0 & 1.1 & .61 & 13 & 7.6 & 3.8 & 1.9 & 4.3 & 2.6 \\
\hline Phenanthrene & 0 & 0 & 1.4 & .60 & 26 & 13 & 5.8 & 2.6 & 6.8 & 3.5 \\
\hline Pyrene & 0 & 0 & 2.5 & .99 & 36 & 19 & 9.2 & 4.0 & 11 & 5.9 \\
\hline Benzo[ghi]perylene & 0 & 0 & 1.2 & .53 & 14 & 8.4 & 4.1 & 2.0 & 4.8 & 2.8 \\
\hline Benzo[a]anthracene ${ }^{1}$ & 3 & 4 & .17 & $<.093$ & 5.0 & 2.5 & 1.5 & .38 & 1.3 & .63 \\
\hline Dibenzo[a,h]anthracene & 14 & 14 & $<.12$ & $<.12$ & .47 & .47 & -- & -- & -- & -- \\
\hline Naphthalene & 15 & 15 & $<.042$ & $<.042$ & $<.042$ & $<.042$ & -- & -- & -- & -- \\
\hline
\end{tabular}

${ }^{1}$ Kaplan-Meier analysis for non-detects was used to calculate summary statistics (Helsel, 2004).

The mean concentrations for TSS, SSC, TP, DP, TZn, and $\mathrm{TCu}$ were lower for this site than those for other parking lots in Wisconsin and Michigan (appendix 2-12) (U.S. Environmental Protection Agency, 2004; Horwatich and others, 2004; Steuer and others, 1997; Bannerman and others, 1992; Bannerman and others, 1983). For example, the mean TSS, TP, and $\mathrm{TCu}$ concentrations measured at a retail parking lot in Madison, Wis., were $91 \mathrm{mg} / \mathrm{L}, 0.26 \mathrm{mg} / \mathrm{L}$, and $47 \mu \mathrm{g} / \mathrm{L}$, respectively (Bannerman and others, 1992), compared to the results of this study: $20 \mathrm{mg} / \mathrm{L}, 0.11 \mathrm{mg} / \mathrm{L}$, and $25 \mu \mathrm{g} / \mathrm{L}$, respectively. These were 2 to 7 times greater than the concentrations for the study presented in table 5. Concentrations of PAHs measured during this study were much higher than those measured for retail parking lots in Madison, Wis. (Selbig and others, 2007), but the concentrations were similar to a parking lot in Marquette, Mich. (about $260 \mathrm{mi}$ to the northeast) (Steuer and others, 1997).

\section{Efficiency Calculations}

Two of the methods typically used by investigators to determine the removal efficiency of constituents by a SFD are the efficiency ratio and summation of loads (SOL) (National Cooperative Highway Research Program, 2006). The efficiency ratio uses event-mean concentration of contaminants sampled from the study. The SOL is used to evaluate the treatment efficiency on a percentage basis by comparing the sum of the influent and effluent loads (the product of multiplying the constituent concentration by the runoff volume) for all monitored events.

Each method uses data from the inlet and outlet to produce a single number that is designed to represent removal efficiency of the device. Unfortunately, these methods are not designed to evaluate the statistical differences in the data, so there is insufficient information generated by the methods to determine whether the differences in water-quality measurements for samples from the inlet and outlet are significant. These efficiency calculations can be supplemented with a statistical test, indicating whether the medians for nonparametric concentrations are statistically significant (Helsel and Hirsch, 1992).

A paired statistical test was used to determine whether the constituent concentrations at the inlet were greater than those at the outlet. A paired statistical test was considered valid for this data set because concentrations at the inlet and outlet were paired for each event. Most of the constituents were lognormally distributed; therefore, the nonparametric one-sided Wilcoxon signed-rank test was applied (Helsel and Hirsch, 
1992). A test for significance and efficiency ratios calculations was not done for calcium and magnesium, because these concentrations are only used in the calculation of hardness.

Concentrations of 8 of the 15 inorganic constituents (excluding PSD) analyzed for the SFD were significantly different at the 95-percent confidence level for the inlet and outlet samples. Concentrations of DP, DCOD, TCOD, TDS, $\mathrm{DCu}$, and $\mathrm{DZn}$ were not significantly different for the inlet and outlet samples. All the constituents that were significantly different were significantly higher in samples from the inlet, except for chloride $(\mathrm{Cl})$, which was significantly higher in the outlet samples, probably owing to winter practices. Eleven of the 18 PAH compounds also were significantly different at the 95-percent confidence level.

\section{Efficiency Ratio}

The efficiency ratio method of calculating efficiencies of a SFD weights all runoff events equally. For example, a large volume of flow with high constituent concentrations has the same weight as a small volume of flow with low constituent concentrations.

The efficiency ratio comparison evaluates treatment efficiency on a percentage basis by dividing the constituent concentration at the outflow by the concentration at the inflow and multiplying the quotient by 100 . The efficiency ratio was calculated for each constituent (and physical property) and each individual runoff event.

The calculation is represented by the following equation:

$$
\begin{gathered}
\text { Efficiency Ratio }=1 \text { - (average outlet concentration/ } \\
\text { average inlet concentration). }
\end{gathered}
$$

Efficiency ratios were calculated for constituents at the 95-percent confidence level (table 7). Efficiencies were calculated for runoff events after November 2005 and did not include bypass events. Runoff events before this date were affected by a lower height of the weir plates for the internal and external bypasses. Efficiency ratios for TSS and TP decreased significantly when the concentrations for one runoff event were removed from the calculations. The inlet TSS concentration (191 mg/L) for runoff event 12 (appendix 2-5) was not only 2 to 3 times higher than the closest concentrations, but it was higher than the inlet concentration of SS (14 mg/L). The SS concentrations were similar or higher than the TSS concentrations for this study. The TP inlet concentrations $(2.0 \mathrm{mg} / \mathrm{L})$ for runoff event 8 (appendix 2-6) was at least 20 times that of any other event. A high TP concentration for event 8 was not accompanied by an increase in DP, which would be expected to increase in most instances. Both of these concentrations were inexplicably high, so an alternate efficiency ratio was determined without the concentrations from the two events (table 7). The efficiency ratios for TSS, SSC, TZn, TCu, and total PAHs for the Madison SFD site were much lower than those for the Milwaukee SFD site (U.S. Environmental Protection Agency, 2004). As with the Milwaukee site, the efficiency ratio for $\mathrm{Cl}$ was negative.
Table 7. Efficiency ratios for selected constituents in samples from a stormwater-filtration device, Madison, Wis., 2005-07.

[Significantly different at the 95-percent level; $\mathrm{mg} / \mathrm{L}$, milligrams per liter; --, significance could not be determined; ( ), efficiency ratio without total suspended solids for runoff event 12 and total phosphorus for runoff event 8 concentrations for these events appeared to be in error; $\mu \mathrm{g} / \mathrm{L}$, micrograms per

\begin{tabular}{|c|c|c|}
\hline Constituent & $\begin{array}{l}\text { Are inlet and } \\
\text { outlet pairs } \\
\text { significantly } \\
\text { different for } \\
\text { median } \\
\text { concentration? }\end{array}$ & $\begin{array}{c}\text { Efficiency } \\
\text { ratio', } \\
\text { in percent }\end{array}$ \\
\hline Total dissolved solids $(\mathrm{mg} / \mathrm{L})^{1}$ & No & -- \\
\hline Total suspended solids $(\mathrm{mg} / \mathrm{L})^{1}$ & Yes & $\begin{array}{c}45 \\
(37)\end{array}$ \\
\hline $\begin{array}{l}\text { Suspended sediment } \\
\text { concentrations }(\mathrm{mg} / \mathrm{L})\end{array}$ & Yes & 37 \\
\hline Volatile solids (mg/L) & Yes & 38 \\
\hline Dissolved phosphorus (mg/L) & No & -- \\
\hline Total phosphorus (mg/L) & Yes & $\begin{array}{l}55 \\
(6)\end{array}$ \\
\hline $\begin{array}{l}\text { Dissolved chemical oxygen } \\
\text { demand }(\mathrm{mg} / \mathrm{L})\end{array}$ & No & -- \\
\hline $\begin{array}{l}\text { Total chemical oxygen } \\
\text { demand }(\mathrm{mg} / \mathrm{L})\end{array}$ & No & -- \\
\hline Dissolved copper $(\mu \mathrm{g} / \mathrm{L})$ & No & -- \\
\hline Total copper $(\mu \mathrm{g} / \mathrm{L})$ & Yes & 22 \\
\hline Dissolved zinc $(\mu \mathrm{g} / \mathrm{L})$ & No & -- \\
\hline Total zinc $(\mu \mathrm{g} / \mathrm{L})$ & Yes & 5 \\
\hline Dissolved chloride (mg/L) & Yes & -18 \\
\hline Total PAHs & Yes & 46 \\
\hline
\end{tabular}
liter; PAHs, polycyclic aromatic hydrocarbons]

${ }^{1}$ Efficiency was calculated when the inlet and outlet of that constituent was sampled for a runoff event.

A total PAH is the sum of 18 compounds analyzed for a runoff event. Several of the 18 compounds were reported as "non-detects"; therefore, a method was needed to sum a total PAH. Methods used to fill in non-detects include using the value of the detection limit, using one-half the detection limit, or using a zero for the detection limit. A total PAH concentration was summed by using 11 significant compounds, and excluding the 7 compounds that were insignificant (greater than 50 percent of the values were non-detects), for all 15 events. Substituting zero for non-detect values, the total PAH concentration was $955 \mu \mathrm{g} / \mathrm{L}$ at the inlet and $512 \mu \mathrm{g} / \mathrm{L}$ at the outlet, which resulted in an efficiency ratio of 46 percent - this is the lowest estimate. Substituting a non-detectable concentration for non-detect values, the total PAH concentration was $984 \mu \mathrm{g} / \mathrm{L}$ at the inlet and $531 \mu \mathrm{g} / \mathrm{L}$ at the outlet resulting in the same efficiency ratio - this is the highest estimate. Because there is much debate on which method to use for substitutions of non-detected values, the total PAH is assumed to fall 
somewhere between these two extremes. To be conservative, this report relies upon the first method, which is a method used in previous USGS reports (Mahlar, 2004).

\section{Summation of Loads}

The SOL method of calculating efficiencies is weighted by the runoff volume event. This method puts emphasis on the load of contaminants leaving a filtration device rather than the concentration. The outlet volumes were used to calculate both the inlet and outlet loads because of the previously described problem with the shifting of the inlet pipe. The SOL is used to evaluate the treatment efficiency on a percentage basis by comparing the sum of the influent and effluent loads (the product of multiplying the constituent concentration by the runoff volume event) for all monitored events.

The equation for calculating the summation of loads is

$$
\text { Summation of loads }=1 \text { - (sum of outlet loads/ }
$$$$
\text { sum of inlet loads). }
$$

SOLs were calculated for constituents at the 95-percent confidence level for a pair test; results indicated that there was a difference in the median concentration (tables 7 and 8 and appendixes 2-9, 2-10, and 2-11). Non-detectable concentrations were substituted with zero to compute loads. As with the efficiency ratios, the SOL for TSS and TP decreased when the TSS loads for event 12 and the TP loads for event 8 were removed from the calculations. For event 12, the TSS concentration runoff at the inlet was about 11 times the median; the small volume $\left(770 \mathrm{ft}^{3}\right)$ of the event resulted in a relatively small change in the SOL (appendix 2-4). Despite the relatively small volume for runoff event $8\left(685 \mathrm{ft}^{3}\right)$, removing the inlet TP concentration that was about 33 times the median significantly decreased the SOL (table 9).
Table 8. Efficiency ratios for selected polycyclic aromatic hydrocarbons in samples from a stormwater-filtration device, Madison, Wis., 2005-07.

[Significantly different at the 95-percent level; --, significance could not be determined; all constituents in micrograms per liter]

\begin{tabular}{|c|c|c|}
\hline Constituent & $\begin{array}{l}\text { Are inlet and } \\
\text { outlet pairs } \\
\text { significantly } \\
\text { different for } \\
\text { median } \\
\text { concentration? }\end{array}$ & $\begin{array}{c}\text { Efficiency } \\
\text { ratio }{ }^{1}, \\
\text { in percent }\end{array}$ \\
\hline 2-Methylnaphthalene & No & -- \\
\hline 1-Methylnaphthalene & No & -- \\
\hline Acenaphthylene & No & -- \\
\hline Acenaphthene & No & -- \\
\hline Anthracene & Yes & 56 \\
\hline Benzo[b]fluoranthene & Yes & 41 \\
\hline Benzo[k]fluoranthene & Yes & 44 \\
\hline Benzo[a]pyrene & Yes & 48 \\
\hline Chrysene & Yes & 45 \\
\hline Fluoranthene & Yes & 49 \\
\hline 9H-Fluorene & No & -- \\
\hline Indeno[1,2,3-cd]pyrene & Yes & 40 \\
\hline Phenanthrene & Yes & 49 \\
\hline Pyrene & Yes & 49 \\
\hline Benzo[ghi]perylene & Yes & 42 \\
\hline Benzo[a]anthracene & Yes & 54 \\
\hline Dibenzo[a,h]anthracene & No & -- \\
\hline Naphthalene & No & -- \\
\hline
\end{tabular}

${ }^{1}$ Efficiency was calculated when the inlet and outlet of that constituent was sampled for a runoff event. 
Table 9. Summation of loads of selected constituents and percent efficiency for a stormwater-filtration device, Madison, Wis., 2005-07.

[lb, pounds; SOL, summation of loads; \%, percent; --, significance could not be determined; ( ), SOL without total suspended solids for event 12 and total phosphorus for event 8 - concentrations for these events appeared to be in error; PAHs, polycyclic aromatic hydrocarbons]

\begin{tabular}{lccc}
\hline \multicolumn{1}{c}{ Constituent } & $\begin{array}{c}\text { Loads at } \\
\text { inlet } \\
\text { (lb) }\end{array}$ & $\begin{array}{c}\text { Loads at } \\
\text { outlet } \\
\text { (Ib) }\end{array}$ & $\begin{array}{c}\text { SOL', } \\
\text { (\%) }\end{array}$ \\
\hline Total dissolved solids & -- & -- & -- \\
Total suspended solids & $\begin{array}{c}\text { 103 } \\
\text { (94) }\end{array}$ & 170 & 32 \\
Suspended sediment & 1116 & 173 & $(26)$ \\
Volatile solids & 21 & 15 & 37 \\
Dissolved phosphorus & -- & -- & 28 \\
Total phosphorus & .27 & .17 & -- \\
& $(.18)$ & & $(6)$ \\
Chemical oxygen demand & -- & -- & -- \\
Dissolved chemical oxygen & -- & -- & -- \\
$\quad$ demand & & & \\
Dissolved copper & -- & -- & -- \\
Total copper & .016 & .012 & 23 \\
Dissolved zinc & -- & -- & -- \\
Total zinc & .080 & .074 & 8 \\
Dissolved chloride & 13 & 16 & -21 \\
Total PAHs & 2.087 & 2.045 & 48 \\
\hline
\end{tabular}

${ }^{1}$ Summation of loads was calculated for only those events when both constituents were sampled.

${ }^{2}$ Total PAH was summed using 11 significant compounds and by replacing non-detect values with zero.
Efficiency ratios and SOL were similar for total PAHs, $\mathrm{TZn}, \mathrm{TCu}$, and $\mathrm{Cl}$. If the events with the inexplicably high TSS and TP concentrations were removed from the calculations, efficiency ratios and SOLs were similar for both TSS and TP. Only SS and volatile suspended solids had as much as a 10-percent difference between the efficiency ratio and SOLs. Compared to the SFD site in Milwaukee (U.S. Environmental Protection Agency, 2004), the SOLs for TSS, SS, TZn, and $\mathrm{TCu}$ were much lower at the Madison site. As for the Milwaukee site, the $\mathrm{SOL}$ for $\mathrm{Cl}$ was negative, as it was at the Madison site.

The SOL for total PAHs (table 9) was computed using the same approach as the efficiency ratio; that is, computing the extreme low and extreme high estimates and assuming that the totals fell somewhere between these extremes. Replacement of non-detects with zero resulted in an inlet load of $0.087 \mathrm{lb}$ and an outlet load of $0.045 \mathrm{lb}$. Replacement of non-detects with the limit of detection (table 2) resulted in an inlet load of $0.09 \mathrm{lb}$ and an outlet load of $0.047 \mathrm{lb}$. To be conservative with estimates for total PAH load, table 9 reports the replacement of non-detects with zero. 


\section{Summary}

This study was conducted in cooperation with the Wisconsin Department of Transportation (WisDOT) and the Wisconsin Department of Natural Resources to evaluate the performance of a stormwater-filtration device (SFD). A SFD was installed in 2003 by the Madison Gas and Electric Company in one of its employee parking lots in June 2003. This type of parking lot was chosen for the test site because the constituent concentrations and particle-size distributions were expected to be similar to those of typical park-and-ride lots operated by the WisDOT. The asphalt parking lot has 181 parking stalls covering 0.91 acres.

The SFD is a concrete structure (16 ft long by $8 \mathrm{ft}$ wide and $5.5 \mathrm{ft}$ deep) that was installed underneath the parking lot, and contains 26 filter cartridges. Each cartridge was filled with a ZPG media composed of zeolite, perlite, and granular activated carbon. Together the cartridges could treat a peak flow of $0.87 \mathrm{ft}^{3} / \mathrm{s}$. When inlet flows exceeded the peak flow, the water bypassed the cartridges by way of an internal weir.

Fifty-one runoff events were monitored for flow and water quality from November 5, 2005, to August 18, 2007. The precipitation depths for these sampled events ranged from 0.19 to $4.93 \mathrm{in}$. The event average runoff coefficient was 63 percent. Thirty-three constituents were analyzed in samples from the inlet and outlet of the device. Eighteen of the constituents were polycyclic aromatic hydrocarbons (PAHs). Samples from 31 runoff events were analyzed for all the constituents except PAHs, which were analyzed in samples from 15 events.

Treatment efficiency of the device was calculated using summation of loads (SOL) and the efficiency ratio methods. Constituents for which concentrations and loads were significantly decreased by the SFD included total suspended solids (TSS), suspended sediment (SS), volatile suspended solids (VSS), total phosphorus (TP), total copper (TCu), total zinc (TZn), and total PAHs. The efficiency ratios for these constituents were $45,37,38,55,22,5$, and 46 percent, respectively. The SOLs for these constituents were 32, 37, 28, 36, 23, 8, and 48 percent, respectively. Both methods resulted in a negative efficiency ratio and SOL for chloride $(\mathrm{Cl})$ (about 20 percent). For dissolved phosphorus, total chemical oxygen demand, dissolved chemical oxygen demand, dissolved zinc, total dissolved solids, and dissolved copper, efficiency ratios and SOLs were not calculated because the differences between the inlet and outlet concentrations were determined to be statistically insignificant.

Efficiency ratios and SOLs were similar for total PAHs, $\mathrm{TZn}, \mathrm{TCu}$, and $\mathrm{Cl}$. When two inexplicably high inlet concentrations were removed from the calculations, the TSS and TP for SOLs and efficiency ratios were also similar. The SOLs and efficiency ratios for TP became 5 and 6 percent, respectively, and the ratios for TSS became 26 and 37 percent, respectively. Only SS and VSS had as much as a 10-percent difference between the efficiency ratio and SOL.
Results from this study can be used to estimate the ability of cartridge filters to reduce the loads of TSS and other contaminants from WisDOT park-and-ride lots. Because of the two inexplicably high inlet concentrations for TSS and $\mathrm{TP}$, the efficiency ratios and SOLs without these high concentrations might better represent the expected reductions for these two contaminants. A different level of performance would be expected for the cartridge filter, at a facility with a different particle-size distribution. For example, the cartridge filter tested by WisDOT in Milwaukee achieved a higher TSS reduction of about 50 percent compared to about 30 percent for this study. For the Milwaukee SFD, the average percent sand in the runoff was about 80 percent, but for this study the average percent sand was about 40 percent.

Models can be used as tools for predicting the level of control to be expected for different types of stormwatercontrol devices, including a SFD. By collecting representative field data at a few locations, a model can be calibrated and verified to perform with moderate reliability for similar sites. Results from this study provide an opportunity to calibrate and verify urban watershed models capable of predicting contaminant loads from various source areas such as parking lots. Models can also be used to predict reduction in loads from different kinds of stormwater-control devices, such as a SFD. Constituent concentrations in samples from flows to the inlet of the SFD provide the data needed to verify the concentrations and runoff predicted by a model. The particle-size distributions, flows, and the reductions in constituent concentrations are needed to evaluate any reduction relation developed for a SFD. Unfortunately, none of the available urban runoff models, including WinSLAMM, include a pollutant reduction relation for a SFD. Results from this project could be instrumental in developing algorithms to predict the efficiency of a SFD based on inlet concentration, particle size, filter media type, and flow rates.

\section{Acknowledgments}

The authors thank David Owens and Mari Danz of the USGS for their tireless efforts in the collection and processing of data. Wendy Braun from the Wisconsin Department of Transportation is thanked for providing project support. The authors also thank James Montgomery of Madison Gas and Electric Company for providing access to the site, for support of the installation of the stormwater-filtration device, and for additional project support. Special thanks also are extended to Jim Bachhuber of Earth Tech, Inc., for his time assisting with the coordination of this project. 


\section{References Cited}

American Public Health Association and others, 1989, Standard methods for the examination of water and wastewater (17th ed.): Washington, D.C., American Public Health Association [variously paged].

Bachhuber, J., Corsi, S., and Bannerman, R., 2001, Test plan for the verification of Arkal Filtration Systems, Inc.-Pressurized stormwater filtration system, St. Mary's Hospital, Green Bay, Wis.: U.S. Environmental Protection Agency, Office of Research and Development [variously paged].

Bannerman, R.T., Baun, K., Bohn, M., Hughes, P.E., and Graczyk, D.J., 1983, Evaluation of urban nonpoint source pollution management in Milwaukee County, Wisconsin-Volume 1 for U.S. Environmental Protection Agency, Region V: Wisconsin Department of Natural Resources Publication PB 84-114164 [variously paged].

Bannerman, R.T., Dodds, R.B., Owens, D.W, and Hughes, P.E., 1992, Source of pollutants in Wisconsin Stormwater-Volume 1 for U.S. Environmental Protection Agency Region V: Wisconsin Department of Natural Resources Grant number C9995007-01 [variously paged].

Burton, G.A., Jr., and Pitt, R.E., 2002, Stormwater effects handbook-A toolbox for watershed managers, scientists, and engineers: Boca Raton, Fla., Lewis Publishers, 929 p.

Corsi, S.R., Greb, S.R., Bannerman, R.T., and Pitt, R.E., 1999, Evaluation of the multi-chambered treatment train, a retrofit water-quality management practice: U.S. Geological Survey Open-File Report 99-270, 24 p.

Design Analysis Associates, 2001, "Smart” SDI-12 Tipping Bucket Rain Gauge-Model H-340SDI: WATERLOG Series Owner's Manual, Version 1.1, 26 p.

Driscoll, E.D., Shelley, P.E., and Strecker, E.W., 1990, Pollutant loadings and impacts from highway stormwater runoff, Volume I-Design procedure: Federal Highway Administration Final Report FHWA-RD-88-006, 61 p.

Graham, M.D., and Beckman Coulter, Inc., 2003, The Coulter Principle-Foundation of an Industry: Journal of the Association for Laboratory Automation, v. 8, issue 6, p. 72-81.

Gray, J.R., Glysson, D.G., Turcois, L.M., and Schwarz, G.E., 2000, Comparability of suspended-sediment concentrations and total suspended solids data: U.S. Geological Survey Water-Resources Investigations Report 00-4191, 14 p.

Helsel, D.R., 2004, Nondetects and data analysis-Statistics for censored environmental data: Wiley-Interscience, $268 \mathrm{p}$.
Helsel, D.R., and Hirsch, R.M., 1992, Statistical methods in water resources: New York, Elsevier, 522 p.

Horowitz, A.J., Hayes, T.S., Gray, J.R., and Capel, P.D., 1997, Selected laboratory tests of the whole-water sample splitting capabilities of the 14-liter churn and the Teflon cone splitters: U.S. Geological Survey Office of Water Quality Technical Memorandum 97.06, 28 p.

Horwatich, J.A., Corsi, R.S., and Bannerman, R.T., 2004, Effectiveness of a pressurized stormwater filtration system in Green Bay, Wisconsin - A study for the Environmental Technology Verification Program of the U.S. Environmental Protection Agency: U.S. Geological Survey Scientific Investigations Report 2004-5222, p 19.

Hunt, W.F., Jarrett, A.R., Smith, J.T., and Sharkey, L.J., 2006, Evaluating bioretention hydrology and nutrient removal at three field sites in North Carolina: ASCE Journal of Irrigation and Drainage Engineering, v. 132, no. 6, p. 600-608.

Mahler, B.J., Van Metre, P.C., Bashara, T.J., Wilson, J.T., and Johns, D.A., 2005, Parking lot sealcoat-An unrecognized source of urban polycyclic aromatic hydrocarbons: Environmental Science and Technology, v, 39, no., 15, p. 55605566.

National Cooperative Highway Research Program, 2006, Evaluation of best management practices for highway runoff control: Washington, D.C., Transportation Research Board, NCHRP Report 565, 111 p., 2 app.

National Oceanic and Atmospheric Administration, 1997, National Climatic Data Center, Dane County Regional Airport Madison precipitation records, 1949-2007: Asheville, N.C., National Climatic Data Center, 42 p.

Pitt, R., 2003, The Source Loading and Management Model (SLAMM), A water quality management planning model for urban stormwater runoff-Chapter 4, Stormwater quality controls in WinSLAMM, accessed [July 2004] at http:// rpitt.eng.ua.edu/SLAMMDETPOND/WinSlamm/Ch4/Ch4. html

Pitt, R., Harrison, R., Henry, C.L., Xue, D., and O'Connor, T., 1999, Enhanced infiltration performance of disturbed urban soils using compost amendments: Water Environment Federation, 72nd Annual Conference \& Exposition, New Orleans, La., October 9-13, 1999.

Prince George's County, 2002, Bioretention design specifications and criteria: St. George, Md., Prince George's County.

Rantz, S.E., 1982, Measurement and computation of streamflow-Volume 2, Computation of discharge: U.S. Geological Survey Water-Supply Paper 2175, p. 285-631. 
Selbig,W.R., Bannerman, Roger, and Bowman, George, 2007, Improving the accuracy of sediment-associated constituent concentrations in whole-stormwater samples by wet sieving: Journal of Environmental Quality, v. 36, no. 1, p. 226-232.

Steuer, J.J., Selbig, W.R., Hornewer, N.J., and Prey, J., 1997, Sources of contamination in an urban basin in Marquette, Michigan, and an analysis of concentrations, loads, and data quality: U.S. Geological Survey Water-Resources Investigations Report 97-4242, 25 p.

Strecker, E.W., Quigley, M.M., and Urbonas, Ben, 2003, A reassessment of the expanded EPA/ASCE National BMP Database, in Proceedings, National Conference on Urban Storm Water-Enhancing Programs at the Local Level, Chicago, Ill., February 17-20, 2003: U.S. Environmental Protection Agency, Office of Research and Development, EPA/625/R-03/003, p. 555-574.

Teledyne Isco, 2004, 2150 Area velocity flow module and sensor-Installation and operation guide: Teledyne Isco, Inc.

U.S. Environmental Protection Agency, 1983, Results of the Nationwide Urban Runoff Program, Volume 1-Final report: Washington, D.C., Water Planning Division, available from the National Technical Information Service as PB84-185552 [variously paged].

U.S. Environmental Protection Agency, 1986, Test methods for evaluation of solid waste ( $3 \mathrm{~d}$ ed.): Washington D.C., Office of Solid Waste and Emergency Response [variously paged].

U.S. Environmental Protection Agency, 2000, Storm water phase II final rule-An overview: U.S. Environmental Protection Agency EPA 833-F-00-001, Fact Sheet 1.0, 4 p.

U.S. Environmental Protection Agency, 2004, Environmental Technology Verification Report-Stormwater source area treatment device-The stormwater management StormFilter using ZPG filter media: 04/17/WQPC-WWF, EPA/600/R-04/125, 65 p., accessed [July 2004] at http:// www.nsf.org/business/water_quality_protection_center/pdf/ SMI_Riverwalk_Verification_Report_Final.pdf
U.S. Environmental Protection Agency, 2005, Environmental Technology Verification Report-Stormwater source area treatment device-Vortechnics, Inc., Vortechs system, model 1000: 05/24/WQPC-WWF, EPA 600/R-05/140, 66 p., accessed [September 2005] at http://www.nsf.org/ business/water_quality_protection_center/pdf/Vortechs_ Verification_Report.pdf

Waschbusch, R.J., 1999, Evaluation of the effectiveness of urban stormwater treatment unit in Madison, Wisconsin, 1996-97: U.S. Geological Survey Water-Resources Investigations Report 99-4195, 49 p.

Waschbusch, R.J., 2003, Data and methods of a 1999-2000 street sweeping study on an urban freeway in Milwaukee County, Wisconsin: U.S. Geological Survey Open-File Report 03-93, 41 p.

Wilde, F.D., ed., 2006, Collection of water samples, in National field manual for the collection of water-quality data: U.S. Geological Survey Techniques of WaterResources Investigations, book 9, chap. A4 [variously paged].

Wisconsin Administrative Code, 2002, Wisconsin Department of Transportation, Construction site erosion control and storm water management procedures for department actions_-Chap. TRANS 401 [variously paged].

Wisconsin Administrative Code, 2004, Wisconsin Department of Natural Resources_-Runoff management_Chap. NR151 [variously paged].

Woodworth, M.T., and Connor, B.F., 2003, Results of the U.S. Geological Survey's analytical evaluation program for standard reference samples distributed in March 2003: U.S. Geological Survey Open-File Report 03-261, 109 p. 


\section{Appendix 1. List of References for Previous Investigations}

Bannerman, R.T., Baun, K., Bohn, M., Hughes, P.E., and Graczyk, D.J., 1983, Evaluation of urban nonpoint source pollution management in Milwaukee County, Wisconsin-Volume 1 for U.S. Environmental Protection Agency, Region V: Wisconsin Department of Natural Resources Publication PB 84-114164 [variously paged].

Bannerman, R.T., Dodds, R.B., Owens, D.W, and Hughes, P.E., 1992, Source of pollutants in Wisconsin Stormwater-Volume 1 for U.S. Environmental Protection Agency Region V: Wisconsin Department of Natural Resources Grant number C9995007-01 [variously paged].

Bannerman, R.T., Legg, A.D., and Greb, S.R., 1996, Quality of Wisconsin stormwater 1989-94: U.S. Geological Survey Open-File Report 96-458, 26 p.

Bannerman, R.T., Owens, D.W., Dodds, R.B., and Hornewer, N.J., 1993, Sources of pollutants in Wisconsin stormwater: Water Science Technology, v. 28, no. 3-5, p. 241-259.

Corsi, S.R., Greb, S.R., Bannerman, R.T., and Pitt, R.E., 1999, Evaluation of the multi-chambered treatment train, a retrofit water-quality management practice: U.S. Geological Survey Open-File Report 99-270, 24 p.

Horwatich, J.A., Corsi, R.S., and Bannerman, R.T., 2004, Effectiveness of a pressurized stormwater filtration system in Green Bay, Wisconsin-A study for the Environmental Technology Verification Program of the U.S. Environmental Protection Agency: U.S. Geological Survey Scientific Investigations Report 2004-5222, p 19.

House, L.B., Waschbusch, R.J., and Hughes, P.E., 1993, Water quality of an urban wet detention pond in Madison Wisconsin, 1987-88: U.S. Geological Survey Open-File Report 93-172, $57 \mathrm{p}$.

Legg, A.D., Bannerman, R.T., and Panuska, J., 1996, Variation in the relation of rainfall to runoff from residential lawns in Madison, Wisconsin, July and August 1995: U.S. Geological Survey Scientific Investigations Report 96-4196, 11 p.

Owens, D.O., Jopke, P., Hall, D.W., Balousek, J., and Roa, A., 2000, Soil erosion from two small construction sites, Dane County, Wisconsin: U.S. Geological Survey Fact Sheet FS-109-00, 4 p.

Selbig, W.R., and Bannerman, R.T., 2007, Evaluation of street sweeping as a stormwater-quality management tool in three residential basins in Madison, Wisconsin: U.S. Geological Survey Scientific Investigations Report 2007-5156, 103 p.

Selbig, W.R., and Bannerman, R.T., 2008, A comparison of runoff quantity and quality from two small basins undergoing implementation of conventional and low-impactdevelopment (LID) strategies, Cross Plains, Wisconsin, water years 1999-2005: U.S. Geological Survey Scientific Investigations Report 2008-5008, 66 p.
Selbig, W.R., Bannerman, R.T., and Bowman, G., 2007, Improving the accuracy of sediment-associated by wet-sieving: Journal of Environmental Quality, v. 36, no. 1, 7 p.

Steuer, J.J., Selbig, W.R., and Hornewer, N.J., 1996, Contaminant concentration in stormwater from eight Lake Superior basin cities, 1993-94: U.S. Geological Survey Open-File Report 96-122, 16 p.

Steuer, J.J., Selbig, W.R., Hornewer, N.J., and Prey, J., 1997, Sources of contamination in an urban basin in Marquette, Michigan, and an analysis of concentrations, loads, and data quality: U.S. Geological Survey Water-Resources Investigations Report 97-4242, 25 p.

U.S. Environmental Protection Agency, 1983, Results of the Nationwide Urban Runoff Program, Volume 1-Final report, Water Planning Division: Washington, D.C., National Technical Information Service PB84-185552 [variously paged].

Walker, J.F., Graczyk, D.J., Corsi, S.R., Owens, D.W., and Wierl, J.A., 1995, Evaluation of nonpoint-source contamination, Wisconsin; land-use and best-management-practices inventory, selected streamwater-quality data, urban-watershed quality assurance and quality control, constituent loads in rural streams, and snowmelt-runoff analysis, water year 1994: U.S. Geological Survey Open-File Report 95-320, $21 \mathrm{p}$.

Waschbusch, R.J., 1995, Stormwater-runoff data in Madison, Wisconsin, 1993-94: U.S. Geological Survey Open-File Report 95-733, 33 p.

Waschbusch, R.J., 1999, Evaluation of the effectiveness of urban stormwater treatment unit in Madison, Wisconsin, 1996-97: U.S. Geological Survey Water-Resources Investigations Report 99-4195, 49 p.

Waschbusch, R.J., 2003, Data and methods of a 1999-2000 street sweeping study on an urban freeway in Milwaukee County, Wisconsin: U.S. Geological Survey Open-File Report 03--93, $41 \mathrm{p}$.

Waschbusch, R.J., Selbig, W.R, and Bannerman, R.T., 1999, Sources of phosphorus in stormwater and street dirt from two urban residential basins in Madison, Wisconsin, 199495: U.S. Geological Survey Water-Resources Investigations Report 99-4021, 47 p. 
This page is intentionally blank. 


\section{Appendix 2. Tables of Sample Analyses Results}


Table 2-1. Concentrations of selected constituents in equipment-field-blank data collected from a stormwater-filtration device, Madison, Wis., 2005-07.

[LOD, limit of detection; LOQ, limit of quantification; mg/L, milligrams per liter; <, less than; --, no sample processed for event; $\mu \mathrm{g} / \mathrm{L}$, micrograms per liter]

\begin{tabular}{|c|c|c|c|c|c|c|c|c|c|c|c|c|}
\hline \multirow[b]{2}{*}{ Constituent } & \multirow[b]{2}{*}{ Unit } & \multicolumn{3}{|c|}{$\begin{array}{c}\text { Blank1 } \\
\text { 7/7/2005 }\end{array}$} & \multicolumn{3}{|c|}{$\begin{array}{c}\text { Blank } 2 \\
\text { 7/13/2006 }\end{array}$} & \multicolumn{3}{|c|}{$\begin{array}{c}\text { Blank } 3 \\
6 / 11 / 2007\end{array}$} & \multirow[b]{2}{*}{ LOD } & \multirow[b]{2}{*}{ LOO } \\
\hline & & 冚 & 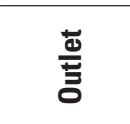 & 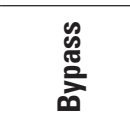 & 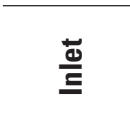 & $\frac{\Xi}{\bar{\Xi}}$ & 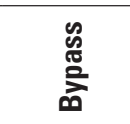 & $\frac{\underline{\underline{\sigma}}}{\underline{E}}$ & $\frac{ \pm}{\bar{\Xi}}$ & 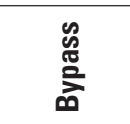 & & \\
\hline Suspended solids, total (mg/L) & $\mathrm{mg} / \mathrm{L}$ & $<2$ & $<2$ & $<2$ & $<2$ & $<2$ & $<2$ & $<2$ & $<2$ & $<2$ & 2 & 7 \\
\hline Suspended-sediment concentration & $\mathrm{mg} / \mathrm{L}$ & $<2$ & $<2$ & $<2$ & $<2$ & $<2$ & $<2$ & $<2$ & $<2$ & $<2$ & 2 & 7 \\
\hline Volatile solids, total & $\mathrm{mg} / \mathrm{L}$ & -- & -- & -- & -- & -- & -- & $<2$ & $<2$ & $<2$ & & \\
\hline Dissolved solids, total & $\mathrm{mg} / \mathrm{L}$ & $<50$ & $<50$ & $<50$ & $<50$ & $<50$ & $<50$ & $<50$ & $<50$ & $<50$ & 50 & 167 \\
\hline Phosphorus, dissolved & $\mathrm{mg} / \mathrm{L}$ & $<.005$ & $<.005$ & $<.005$ & .012 & .011 & .011 & $<.005$ & $<.005$ & $<.005$ & .005 & .016 \\
\hline Phosphorus, total & $\mathrm{mg} / \mathrm{L}$ & $<.005$ & $<.005$ & $<.005$ & .011 & .011 & .01 & $<.005$ & $<.005$ & $<.005$ & .005 & .016 \\
\hline Chemical oxygen demand, total & $\mathrm{mg} / \mathrm{L}$ & 10 & $<9$ & $<9$ & $<9$ & $<9$ & $<9$ & $<9$ & $<9$ & $<9$ & 9 & 28 \\
\hline Chemical oxygen demand, dissolved & $\mathrm{mg} / \mathrm{L}$ & -- & -- & -- & $<9$ & $<9$ & $<9$ & $<9$ & $<9$ & $<9$ & $<9$ & 28 \\
\hline Chloride, dissolved & $\mathrm{mg} / \mathrm{L}$ & $<.6$ & $<.6$ & $<.6$ & $<.6$ & $<.6$ & $<.6$ & $<1$ & $<1$ & $<1$ & 2.0 & 3.3 \\
\hline Copper, dissolved & $\mu \mathrm{g} / \mathrm{L}$ & 1.3 & $<1$ & 1.0 & $<2$ & $<1$ & $<1$ & $<2$ & $<2$ & $<2$ & 1 & 3 \\
\hline Copper, total recoverable & $\mu \mathrm{g} / \mathrm{L}$ & 1 & 1 & 2 & $<1$ & $<1$ & -- & $<2$ & $<2$ & $<2$ & 1 & 3 \\
\hline Zinc, dissolved & $\mu \mathrm{g} / \mathrm{L}$ & $<16$ & $<16$ & $<16$ & $<1$ & 6 & $<1$ & $<1$ & $<1$ & $<1$ & 16 & 50 \\
\hline Zinc, total recoverable & $\mu \mathrm{g} / \mathrm{L}$ & $<16$ & $<16$ & $<16$ & $<3$ & $<3$ & $<3$ & $<3$ & $<3$ & $<3$ & 16 & 50 \\
\hline Calcium, total recoverable & $\mathrm{mg} / \mathrm{L}$ & $<.2$ & $<.2$ & $<.2$ & $<.1$ & $<.1$ & $<.1$ & $<.1$ & $<.1$ & $<.1$ & .200 & .070 \\
\hline Magnesium, total recoverable & $\mathrm{mg} / \mathrm{L}$ & $<.2$ & $<.2$ & $<.2$ & $<.1$ & $<.1$ & $<.1$ & $<.1$ & $<.1$ & $<.1$ & .200 & .070 \\
\hline
\end{tabular}


Table 2-2. Relative percent difference for concentrations of selected constituents in field replicate samples collected from a stormwater-filtration device and sample, Madison, Wis., 2005-07.

[Target, minimum criteria for acceptance of quality-control-sample data without qualification; \%, percent; Rep, replicate; RPD, relative percent difference; mg/L, milligrams per liter; na, not available; --, no sample processed for event; $<$, less than; $\mu \mathrm{g} / \mathrm{L}$, micrograms per liter]

\begin{tabular}{|c|c|c|c|c|c|c|c|c|c|c|c|c|c|c|}
\hline \multirow{2}{*}{ Constituent } & \multirow{2}{*}{$\begin{array}{c}\text { Target } \\
(\%)\end{array}$} & \multirow{2}{*}{ Site } & \multicolumn{3}{|c|}{$\begin{array}{c}\text { Event } 1 \\
11 / 05 / 2005\end{array}$} & \multicolumn{3}{|c|}{$\begin{array}{c}\text { Event } 9 \\
4 / 16 / 2006\end{array}$} & \multicolumn{3}{|c|}{$\begin{array}{l}\text { Event } 23 \\
8 / 23 / 06\end{array}$} & \multicolumn{3}{|c|}{$\begin{array}{c}\text { Event } 44 \\
7 / 26 / 2007\end{array}$} \\
\hline & & & Rep 1a & $\operatorname{Rep} \mathbf{1 b}$ & $\begin{array}{l}\text { RPD } \\
(\%)\end{array}$ & $\operatorname{Rep} 2 a$ & Rep 2b & $\begin{array}{l}\text { RPD } \\
(\%)\end{array}$ & Rep 3a & $\operatorname{Rep} 3 \mathbf{b}$ & $\begin{array}{l}\text { RPD } \\
(\%)\end{array}$ & Rep 4a & Rep 4b & $\begin{array}{l}\text { RPD } \\
(\%)\end{array}$ \\
\hline \multirow{2}{*}{$\begin{array}{l}\text { Suspended } \\
\text { solids, total }(\mathrm{mg} / \mathrm{L})\end{array}$} & \multirow[t]{2}{*}{30} & Inlet & 13 & 14 & -7 & 34 & 35 & -3 & 22 & 23 & -4 & 15 & 16 & -6 \\
\hline & & Outlet & 8 & 8 & 0 & 20 & 20 & 0 & 11 & 17 & -43 & 13 & 12 & 8 \\
\hline \multirow{2}{*}{$\begin{array}{l}\text { Suspended sediment } \\
\text { concentration }(\mathrm{mg} / \mathrm{L})\end{array}$} & \multirow[t]{2}{*}{ na } & Inlet & 13 & 13 & 0 & 53 & 45 & 16 & 33 & 32 & 3 & 12 & 14 & -15 \\
\hline & & Outlet & 7 & 7 & 0 & 20 & 20 & 0 & 9 & 9 & 0 & 10 & 9 & 11 \\
\hline \multirow{2}{*}{$\begin{array}{l}\text { Volatile suspended } \\
\text { solids, }(\mathrm{mg} / \mathrm{L})\end{array}$} & \multirow[t]{2}{*}{ na } & Inlet & -- & -- & -- & 9 & 10 & -11 & 7 & 7 & 0 & 7 & 7 & 0 \\
\hline & & Outlet & -- & -- & -- & 6 & 6 & 0 & 5 & 5 & 0 & 5 & 5 & 0 \\
\hline \multirow{2}{*}{$\begin{array}{l}\text { Suspended solids, } \\
\text { dissolved (mg/L) }\end{array}$} & \multirow[t]{2}{*}{30} & Inlet & $<50$ & $<50$ & -- & $<50$ & $<50$ & -- & $<50$ & $<50$ & -- & $<50$ & $<50$ & -- \\
\hline & & Outlet & $<50$ & $<50$ & -- & $<50$ & $<50$ & -- & $<50$ & $<50$ & -- & 52 & $<50$ & -- \\
\hline \multirow{2}{*}{$\begin{array}{l}\text { Phosphorus, dissolved } \\
\quad(\mathrm{mg} / \mathrm{L})\end{array}$} & \multirow[t]{2}{*}{30} & Inlet & .062 & .061 & .16 & .02 & .02 & 0 & .026 & .028 & -7 & .053 & .055 & -4 \\
\hline & & Outlet & .07 & .064 & 9.0 & .012 & .012 & 0 & .031 & .030 & 3 & .038 & .039 & -3 \\
\hline \multirow[t]{2}{*}{ Phosphorus, total (mg/L) } & \multirow{2}{*}{30} & Inlet & .089 & .089 & 0 & .058 & .059 & -2 & .052 & .053 & -2 & .072 & .072 & 0 \\
\hline & & Outlet & .079 & .079 & 0 & .040 & .044 & -10 & .043 & .041 & 5 & .077 & .072 & -1 \\
\hline \multirow{2}{*}{$\begin{array}{l}\text { Chemical oxygen } \\
\text { demand, total }(\mathrm{mg} / \mathrm{L})\end{array}$} & \multirow[t]{2}{*}{ na } & Inlet & 19 & $<9$ & -- & 20 & 26 & -26 & 15 & 28 & -60 & 44 & 46 & -4 \\
\hline & & Outlet & 17 & 15 & 13 & 21 & 13 & 47 & 22 & 33 & -40 & 58 & 60 & -3 \\
\hline \multirow{2}{*}{$\begin{array}{l}\text { Chemical oxygen } \\
\text { demand, dissolved } \\
(\mathrm{mg} / \mathrm{L})\end{array}$} & \multirow[t]{2}{*}{ na } & Inlet & 16 & 15 & 6 & 22 & $<9$ & -- & 41 & 43 & -5 & 41 & 43 & -5 \\
\hline & & Outlet & -- & -- & -- & 15 & 23 & -42 & $<9$ & 20 & -- & 46 & 36 & 24 \\
\hline \multirow{2}{*}{$\begin{array}{l}\text { Chloride, dissolved } \\
\quad(\mathrm{mg} / \mathrm{L})\end{array}$} & \multirow[t]{2}{*}{25} & Inlet & 1.7 & 1.7 & 0 & 1.9 & 1.8 & 5 & .8 & .8 & 0 & 1.2 & 1.2 & 0 \\
\hline & & Outlet & 2 & 2 & 0 & 2.1 & 1.9 & 10 & -- & -- & -- & 2.1 & 2 & 5 \\
\hline \multirow[t]{2}{*}{ Copper, dissolved $(\mu \mathrm{g} / \mathrm{L})$} & \multirow[t]{2}{*}{25} & Inlet & 1.9 & 1.8 & 5 & $<1$ & $<1$ & -- & $<2$ & $<2$ & -- & 4 & 3 & 14 \\
\hline & & Outlet & 1.8 & 1.9 & -5 & 1 & 1 & 0 & $<2$ & $<2$ & -- & 3 & 3 & 0 \\
\hline \multirow{2}{*}{$\begin{array}{l}\text { Copper, total recoverable } \\
(\mu \mathrm{g} / \mathrm{L})\end{array}$} & \multirow[t]{2}{*}{25} & Inlet & 3 & 3 & 0 & 4 & 4 & 0 & 3 & 4 & -29 & 6 & 6 & 0 \\
\hline & & Outlet & 3 & 3 & 0 & 3 & 3 & 0 & 2 & 3 & -40 & 4 & 5 & -22 \\
\hline
\end{tabular}


Table 2-2. Relative percent difference for concentrations of selected constituents in field replicate samples collected from a stormwater-filtration device and sample, Madison, Wis., 2005-07. - Continued

[Target, minimum criteria for acceptance of quality-control-sample data without qualification; \%, percent; Rep, replicate; RPD, relative percent difference; mg/L, milligrams per liter; na, not available; ,-- no sample processed for event; $<$, less than; $\mu \mathrm{g} / \mathrm{L}$, micrograms per liter]

\begin{tabular}{|c|c|c|c|c|c|c|c|c|c|c|c|c|c|c|}
\hline \multirow{2}{*}{ Constituent } & \multirow{2}{*}{$\begin{array}{c}\text { Target } \\
(\%)\end{array}$} & \multirow{2}{*}{ Site } & \multicolumn{3}{|c|}{$\begin{array}{c}\text { Event } 1 \\
11 / 05 / 2005\end{array}$} & \multicolumn{3}{|c|}{$\begin{array}{c}\text { Event } 9 \\
4 / 16 / 2006\end{array}$} & \multicolumn{3}{|c|}{$\begin{array}{l}\text { Event } 23 \\
8 / 23 / 06\end{array}$} & \multicolumn{3}{|c|}{$\begin{array}{l}\text { Event } 44 \\
7 / 26 / 2007\end{array}$} \\
\hline & & & Rep 1a & Rep 1b & $\begin{array}{l}\text { RPD } \\
(\%)\end{array}$ & Rep 2a & Rep 2b & $\begin{array}{l}\text { RPD } \\
(\%)\end{array}$ & Rep 3a & $\operatorname{Rep} 3 \mathbf{b}$ & $\begin{array}{l}\text { RPD } \\
(\%)\end{array}$ & Rep 4a & Rep 4b & $\begin{array}{l}\text { RPD } \\
(\%)\end{array}$ \\
\hline \multirow[t]{2}{*}{ Zinc, dissolved $(\mu \mathrm{g} / \mathrm{L})$} & \multirow[t]{2}{*}{25} & Inlet & $<16$ & $<16$ & -- & 6 & 6 & 0 & 7 & 8 & -13 & 22 & 21 & 5 \\
\hline & & Outlet & $<16$ & $<16$ & -- & 11 & 11 & 0 & 10 & 10 & 0 & 20 & 21 & -5 \\
\hline \multirow{2}{*}{$\begin{array}{l}\text { Zinc, total recoverable } \\
\qquad(\mu \mathrm{g} / \mathrm{L})\end{array}$} & \multirow[t]{2}{*}{25} & Inlet & $<16$ & $<16$ & -- & 24 & 43 & -57 & 24 & 27 & -12 & 33 & 34 & -3 \\
\hline & & Outlet & $<16$ & $<16$ & -- & 21 & 20 & 5 & 18 & 19 & -5 & 30 & 32 & -6 \\
\hline \multirow{2}{*}{$\begin{array}{l}\text { Calcium, total } \\
\text { recoverable }(\mathrm{mg} / \mathrm{L})\end{array}$} & \multirow[t]{2}{*}{25} & Inlet & 4.2 & 4.2 & 0 & 4.5 & 8.6 & -63 & 3.8 & 3.9 & -3 & 4.3 & 4.3 & 0 \\
\hline & & Outlet & 4.3 & 4.2 & 2 & 3.6 & 3.5 & 3 & 3.3 & 3.4 & -3 & 6.1 & 6.4 & -5 \\
\hline \multirow{2}{*}{$\begin{array}{l}\text { Magnesium, total } \\
\text { recoverable }(\mathrm{mg} / \mathrm{L})\end{array}$} & \multirow[t]{2}{*}{25} & Inlet & 1.2 & 1.3 & -8 & 1.7 & 2.2 & -26 & 1.2 & 1.2 & 0 & 1.2 & 1.2 & 0 \\
\hline & & Outlet & .9 & .9 & 0 & 1.1 & 1.1 & 0 & .8 & .8 & 0 & 1.6 & 1.7 & -6 \\
\hline
\end{tabular}


Table 2-3. Precipitation during sampling events from a stormwater-filtration device, Madison, Wis., 2005-07.

[mm, month; dd, day; yyyy, year; hh, hour; mm, min, minute; in., inch; in/h, inch per hour; ft-lb/acre, foot per pound per acre; $\mathrm{ft}^{3}$, cubic foot]

\begin{tabular}{|c|c|c|c|c|c|c|c|c|c|}
\hline $\begin{array}{l}\text { Sampling } \\
\text { event } \\
\text { number }\end{array}$ & $\begin{array}{c}\text { Start date } \\
\text { and time } \\
\text { (mm/dd/yyyy } \\
\text { hh:mm) }\end{array}$ & $\begin{array}{c}\text { End date } \\
\text { and time } \\
\text { (mm/dd/yyyy } \\
\text { hh:mm) }\end{array}$ & $\begin{array}{l}\text { Precipi- } \\
\text { tation } \\
\text { duration } \\
\text { (hh:mm) }\end{array}$ & $\begin{array}{l}\text { Total } \\
\text { precipi- } \\
\text { tation } \\
\text { (in.) }\end{array}$ & $\begin{array}{c}\text { Max } \\
\text { 15-min } \\
\text { intensity } \\
\text { (in/h) }\end{array}$ & $\begin{array}{c}\text { Max } \\
\text { 30-min } \\
\text { intensity } \\
\text { (in/h) }\end{array}$ & $\begin{array}{l}\text { Erosivity } \\
\text { index } \\
\text { (hundreds } \\
\text { of } \mathrm{ft}-\mathrm{lb} / \\
\text { acre/in/hr) }\end{array}$ & $\begin{array}{l}\text { Precipitation } \\
\text { volume } \\
\left(\mathrm{ft}^{3}\right)\end{array}$ & $\begin{array}{c}\text { Antecedent } \\
\text { dry times } \\
\text { (dd hh:mm) }\end{array}$ \\
\hline 1 & 11/05/2005 17:27 & $11 / 05 / 200523: 52$ & $06: 25$ & 1.01 & 0.324 & 0.27 & 2.4 & 3,370 & $0601: 55$ \\
\hline 1 & $11 / 06 / 200501: 33$ & $11 / 06 / 2005$ 05:28 & $03: 55$ & .23 & .14 & .11 & .21 & 720 & 00 01:41 \\
\hline 1 & $11 / 12 / 200521: 47$ & $11 / 12 / 2005$ 22:05 & $00: 18$ & .07 & .22 & -- & -- & 220 & $0004: 39$ \\
\hline 1 & $11 / 14 / 200518: 38$ & $11 / 14 / 200521: 16$ & $02: 38$ & .08 & .07 & .07 & .05 & 250 & $0120: 33$ \\
\hline 2 & 11/15/2005 13:09 & $11 / 15 / 200520: 23$ & $07: 14$ & .77 & .32 & .31 & 2.0 & 2,390 & $0015: 53$ \\
\hline 2 & $11 / 15 / 200521: 25$ & $11 / 16 / 200501: 16$ & $03: 51$ & .05 & .04 & .02 & .01 & 170 & 00 01:02 \\
\hline 3 & $12 / 23 / 200508: 45$ & $12 / 23 / 200512: 13$ & $03: 28$ & .17 & .11 & .11 & .15 & 530 & $2501: 15$ \\
\hline 3 & 01/01/2006 20:21 & $01 / 01 / 200622: 47$ & $02: 26$ & .10 & .07 & .05 & .04 & 310 & 09 08:08 \\
\hline 3 & 01/02/2006 06:58 & $01 / 02 / 200614: 23$ & $07: 25$ & .73 & .29 & .25 & 1.5 & 2,250 & $0008: 11$ \\
\hline 3 & 01/24/2006 09:06 & 01/24/2006 10:09 & 01:03 & .10 & .18 & .14 & .12 & 310 & $2118: 43$ \\
\hline 3 & 01/28/2006 05:16 & 01/28/2006 06:04 & $00: 48$ & .08 & .18 & .13 & .08 & 250 & 03 19:07 \\
\hline 3 & 01/28/2006 09:02 & 01/28/2006 09:30 & $00: 28$ & .05 & .14 & -- & -- & 170 & $0002: 58$ \\
\hline 3 & $01 / 28 / 200612: 34$ & 01/28/2006 17:22 & $04: 48$ & .23 & .11 & .09 & .17 & 720 & 00 03:04 \\
\hline 3 & 01/28/2006 19:48 & 01/29/2006 08:42 & $12: 54$ & .80 & .18 & .14 & .95 & 2,470 & $0002: 26$ \\
\hline 4 & 03/17/2006 12:07 & 03/17/2006 13:13 & 01:06 & .10 & .24 & .18 & .15 & 310 & 04 08:33 \\
\hline 4 & 03/23/2006 16:00 & 03/23/2006 17:24 & $01: 24$ & .10 & .16 & .12 & .10 & 310 & 06 02:47 \\
\hline 4 & 03/30/2006 22:42 & 03/31/2006 02:10 & $03: 28$ & .18 & .16 & .12 & .18 & 560 & 07 05:18 \\
\hline 4 & 03/31/2006 12:52 & 03/31/2006 13:32 & $00: 40$ & .07 & .12 & .12 & .07 & 220 & $0010: 42$ \\
\hline 5 & 04/02/2006 11:02 & 04/02/2006 13:10 & 02:08 & .25 & .28 & .20 & .42 & 770 & $0121: 30$ \\
\hline 6 & $04 / 02 / 200620: 32$ & 04/02/2006 22:06 & $01: 34$ & .37 & .40 & .36 & 1.1 & 1,140 & 00 07:22 \\
\hline 6 & $04 / 02 / 200623: 31$ & 04/03/2006 05:25 & $05: 54$ & .72 & .24 & .20 & 1.2 & 2,220 & $0001: 25$ \\
\hline 7 & 04/06/2006 22:00 & 04/07/2006 07:54 & $09: 54$ & 1.61 & .88 & .72 & 10 & 4,970 & $0316: 35$ \\
\hline 8 & 04/12/2006 05:06 & 04/12/2006 07:45 & $02: 39$ & .44 & .48 & .36 & 1.3 & 1,360 & $0421: 12$ \\
\hline 8 & $04 / 13 / 200621: 37$ & 04/13/2006 21:40 & 00:03 & .10 & -- & -- & -- & 310 & $0113: 52$ \\
\hline 9 & $04 / 16 / 200603: 37$ & 04/16/2006 04:29 & $00: 52$ & .11 & .24 & .18 & .17 & 340 & 02 05:57 \\
\hline 9 & 04/16/2006 09:18 & 04/16/2006 10:22 & 01:04 & .09 & .24 & .14 & .11 & 280 & 00 04:49 \\
\hline 9 & $04 / 16 / 2006$ 13:23 & 04/16/2006 16:40 & $03: 17$ & .75 & .96 & .74 & 4.9 & 2,310 & 00 03:01 \\
\hline
\end{tabular}


Table 2-3. Precipitation during sampling events from a stormwater-filtration device, Madison, Wis., 2005-07. —Continued [mm, month; dd, day; yyyy, year; hh, hour; mm, min, minute; in., inch; in/h, inch per hour; ft-lb/acre, foot per pound per acre; $\mathrm{ft}^{3}$, cubic foot]

\begin{tabular}{|c|c|c|c|c|c|c|c|c|c|}
\hline $\begin{array}{l}\text { Sampling } \\
\text { event } \\
\text { number }\end{array}$ & $\begin{array}{c}\text { Start date } \\
\text { and time } \\
\text { (mm/dd/yyyy } \\
\text { hh:mm) }\end{array}$ & $\begin{array}{c}\text { End date } \\
\text { and time } \\
\text { (mm/dd/yyyy } \\
\text { hh:mm) }\end{array}$ & $\begin{array}{l}\text { Precipi- } \\
\text { tation } \\
\text { duration } \\
\text { (hh:mm) }\end{array}$ & $\begin{array}{l}\text { Total } \\
\text { precipi- } \\
\text { tation } \\
\text { (in.) }\end{array}$ & $\begin{array}{c}\text { Max } \\
\text { 15-min } \\
\text { intensity } \\
\text { (in/h) }\end{array}$ & $\begin{array}{c}\text { Max } \\
\text { 30-min } \\
\text { intensity } \\
\text { (in/h) }\end{array}$ & $\begin{array}{l}\text { Erosivity } \\
\text { index } \\
\text { (hundreds } \\
\text { of ft-lb/ } \\
\text { acre/in/hr) }\end{array}$ & $\begin{array}{c}\text { Precipitation } \\
\text { volume } \\
\left(\mathrm{ft}^{3}\right)\end{array}$ & $\begin{array}{c}\text { Antecedent } \\
\text { dry times } \\
\text { (dd hh:mm) }\end{array}$ \\
\hline 9 & 04/19/2006 04:28 & 04/19/2006 05:47 & 01:19 & 0.16 & 0.56 & 0.28 & 0.42 & 490 & 02 11:48 \\
\hline 9 & $04 / 22 / 200601: 26$ & 04/22/2006 01:41 & $00: 15$ & .09 & .36 & -- & -- & 280 & 02 19:39 \\
\hline 10 & $04 / 29 / 200623: 27$ & 04/30/2006 09:30 & $10: 03$ & 1.19 & .44 & .36 & 3.6 & 3,670 & 00 01:05 \\
\hline 11 & 05/01/2006 20:34 & 05/01/2006 21:36 & 01:02 & .41 & 1.36 & .78 & 3.0 & 1,270 & 01 11:04 \\
\hline 11 & 05/09/2006 10:37 & 05/09/2006 12:24 & 01:47 & .05 & .07 & .05 & .02 & 170 & 07 13:01 \\
\hline 12 & 05/09/2006 13:46 & 05/09/2006 17:22 & $03: 36$ & .41 & .29 & .25 & .84 & 1,250 & $0001: 22$ \\
\hline 13 & 05/13/2006 10:40 & 05/13/2006 11:32 & $00: 52$ & .05 & .11 & .07 & .03 & 170 & $0106: 56$ \\
\hline 13 & 05/13/2006 15:38 & 05/13/2006 16:45 & 01:07 & .10 & .14 & .11 & .09 & 310 & 00 04:06 \\
\hline 13 & 05/15/2006 15:38 & 05/15/2006 15:45 & 00:07 & .06 & -- & -- & -- & 190 & $0122: 53$ \\
\hline 14 & 05/16/2006 14:49 & 05/16/2006 15:42 & $00: 53$ & .10 & .32 & .18 & .15 & 310 & 00 23:04 \\
\hline 14 & 05/16/2006 17:50 & 05/16/2006 17:59 & 00:09 & .09 & -- & -- & -- & 280 & 00 02:08 \\
\hline 15 & 05/17/2006 15:25 & 05/17/2006 16:13 & $00: 48$ & .36 & .83 & .50 & 1.7 & 1,110 & $0021: 26$ \\
\hline 15 & 05/24/2006 18:37 & 05/24/2006 19:03 & $00: 26$ & 1.83 & 6.13 & -- & -- & 5,660 & 07 02:24 \\
\hline 15 & $05 / 24 / 200621: 11$ & $05 / 24 / 200621: 37$ & $00: 26$ & .10 & .36 & -- & -- & 310 & 00 02:08 \\
\hline 16 & 06/18/2006 07:19 & 06/18/2006 09:39 & $02: 20$ & .08 & .11 & .07 & .05 & 250 & 03 18:16 \\
\hline 16 & $06 / 18 / 200612: 16$ & 06/18/2006 13:11 & $00: 55$ & .09 & .25 & .14 & .11 & 280 & 00 02:37 \\
\hline 16 & $06 / 21 / 200605: 52$ & 06/21/2006 06:49 & $00: 57$ & .09 & .32 & .16 & .12 & 280 & 02 16:41 \\
\hline 16 & 06/24/2006 08:51 & 06/24/2006 11:02 & 02:11 & .06 & .07 & .05 & .03 & 180 & 03 02:02 \\
\hline 17 & $06 / 25 / 200617: 40$ & $06 / 26 / 200606: 16$ & $12: 36$ & .45 & .12 & .10 & .38 & 1,390 & $0106: 38$ \\
\hline 18 & 07/11/2006 07:17 & 07/11/2006 16:08 & 08:51 & 1.87 & .86 & .76 & 12 & 5,770 & 15 01:01 \\
\hline 19 & 07/20/2006 02:33 & 07/20/2006 06:59 & $04: 26$ & .88 & 1.44 & .90 & 7.4 & 2,720 & $0810: 25$ \\
\hline 19 & $07 / 22 / 200616: 31$ & 07/22/2006 17:51 & $01: 20$ & .16 & .48 & .28 & .39 & 490 & 02 09:32 \\
\hline 19 & $07 / 25 / 200623: 47$ & 07/26/2006 01:08 & 01:21 & .05 & .11 & .05 & .02 & 170 & 03 05:56 \\
\hline 19 & 07/27/2006 11:44 & 07/27/2006 13:42 & $01: 58$ & 4.05 & 7.01 & 5.23 & 106 & 12,500 & 01 10:36 \\
\hline 20 & 08/06/2006 05:43 & 08/06/2006 11:08 & $05: 25$ & .87 & .47 & .32 & 2.3 & 2,690 & 09 16:01 \\
\hline 21 & 08/09/2006 18:42 & 08/09/2006 19:04 & $00: 22$ & .21 & .79 & -- & -- & 640 & 03 07:34 \\
\hline 22 & 08/17/2006 15:02 & 08/17/2006 17:23 & $02: 21$ & .22 & .61 & .36 & .67 & 670 & 07 19:58 \\
\hline
\end{tabular}


Table 2-3. Precipitation during sampling events from a stormwater-filtration device, Madison, Wis., 2005-07. —Continued [mm, month; dd, day; yyyy, year; hh, hour; $\mathrm{mm}$, min, minute; in., inch; in/h, inch per hour; ft-lb/acre, foot per pound per acre; $\mathrm{ft}^{3}$, cubic foot]

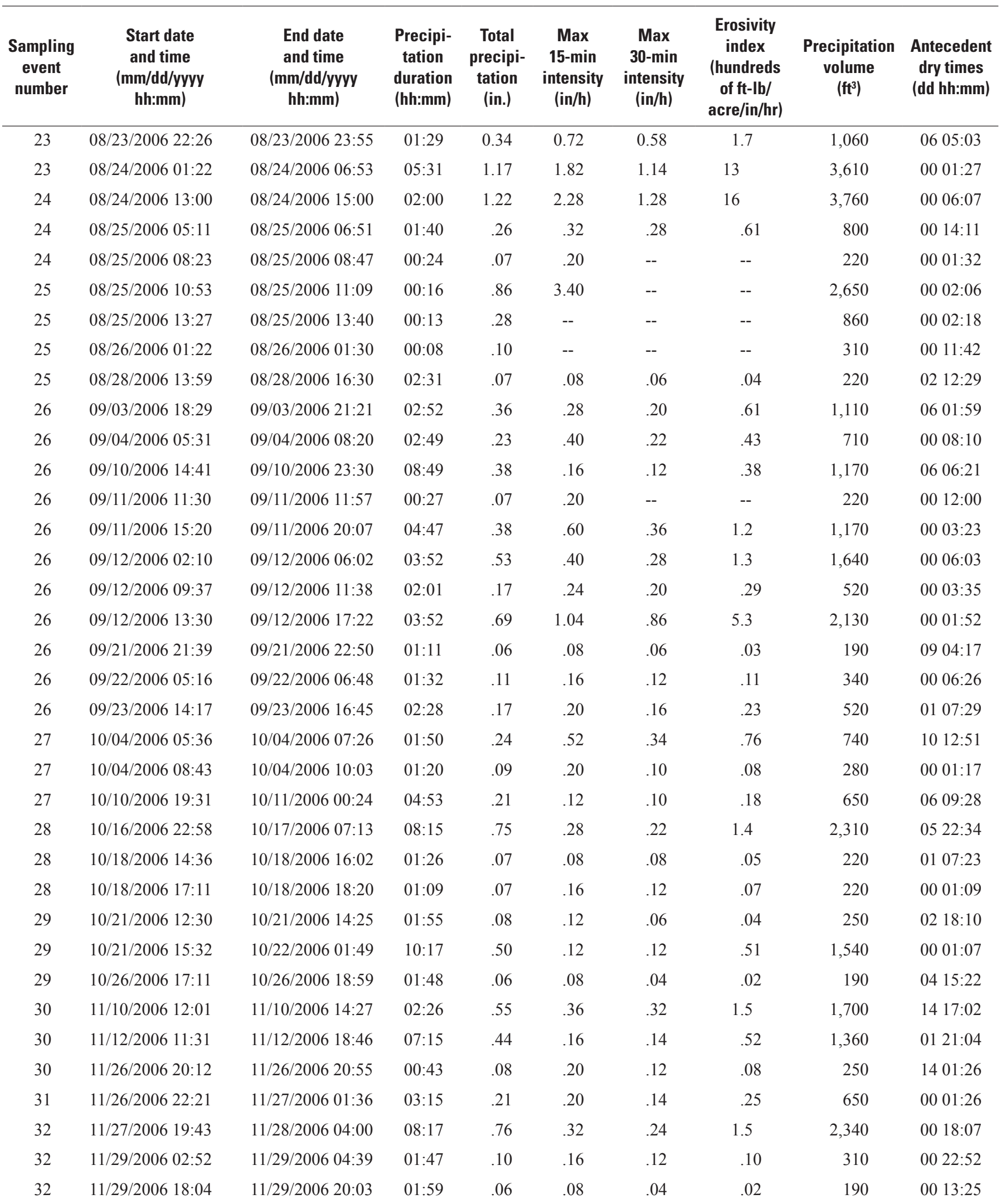


Table 2-3. Precipitation during sampling events from a stormwater-filtration device, Madison, Wis., 2005-07. —Continued [mm, month; dd, day; yyyy, year; hh, hour; mm, min, minute; in., inch; in/h, inch per hour; ft-lb/acre, foot per pound per acre; $\mathrm{ft}^{3}$, cubic foot]

\begin{tabular}{|c|c|c|c|c|c|c|c|c|c|}
\hline $\begin{array}{l}\text { Sampling } \\
\text { event } \\
\text { number }\end{array}$ & $\begin{array}{c}\text { Start date } \\
\text { and time } \\
\text { (mm/dd/yyyy } \\
\text { hh:mm) }\end{array}$ & $\begin{array}{c}\text { End date } \\
\text { and time } \\
\text { (mm/dd/yyyy } \\
\text { hh:mm) }\end{array}$ & $\begin{array}{l}\text { Precipi- } \\
\text { tation } \\
\text { duration } \\
\text { (hh:mm) }\end{array}$ & $\begin{array}{l}\text { Total } \\
\text { precipi- } \\
\text { tation } \\
\text { (in.) }\end{array}$ & $\begin{array}{c}\text { Max } \\
\text { 15-min } \\
\text { intensity } \\
\text { (in/h) }\end{array}$ & $\begin{array}{c}\text { Max } \\
\text { 30-min } \\
\text { intensity } \\
\text { (in/h) }\end{array}$ & $\begin{array}{c}\text { Erosivity } \\
\text { index } \\
\text { (hundreds } \\
\text { of ft-lb/ } \\
\text { acre/in/hr) }\end{array}$ & $\begin{array}{l}\text { Precipitation } \\
\text { volume } \\
\left(\mathrm{ft}^{3}\right)\end{array}$ & $\begin{array}{c}\text { Antecedent } \\
\text { dry times } \\
\text { (dd hh:mm) }\end{array}$ \\
\hline 32 & 12/20/2006 19:45 & 12/21/2006 03:39 & 07:54 & 0.23 & 0.08 & 0.08 & 0.16 & 710 & $2023: 42$ \\
\hline 33 & 12/21/2006 06:26 & 12/21/2006 13:52 & $07: 26$ & .47 & .24 & .20 & .79 & 1,450 & 00 02:47 \\
\hline 34 & $12 / 22 / 200612: 54$ & $12 / 22 / 200615: 39$ & 02:45 & .23 & .36 & .28 & .54 & 710 & 00 23:02 \\
\hline 34 & 12/31/2006 07:12 & $12 / 31 / 200610: 24$ & 03:12 & .23 & .28 & .24 & .47 & 710 & 08 15:33 \\
\hline 34 & 01/26/2007 13:45 & 01/26/2007 14:44 & 00:59 & .14 & .28 & .20 & .24 & 430 & $2603: 21$ \\
\hline 34 & 02/25/2007 06:09 & 02/25/2007 15:46 & 09:37 & .46 & .16 & .12 & .47 & 1,420 & 29 15:25 \\
\hline 34 & 02/26/2007 14:04 & 02/26/2007 16:04 & 02:00 & .10 & .08 & .08 & .07 & 310 & $0022: 18$ \\
\hline 34 & 03/01/2007 10:11 & 03/01/2007 14:34 & 04:23 & .31 & .40 & .30 & .78 & 960 & 02 18:07 \\
\hline 34 & 03/09/2007 15:02 & 03/09/2007 18:38 & 03:36 & .20 & .12 & .10 & .17 & 620 & 08 00:28 \\
\hline 34 & 03/14/2007 16:38 & 03/14/2007 18:37 & 01:59 & .06 & .08 & .04 & .02 & 190 & 04 22:00 \\
\hline 34 & 03/21/2007 03:16 & 03/21/2007 05:45 & 02:29 & .11 & .20 & .14 & .13 & 340 & 06 08:39 \\
\hline 34 & 03/21/2007 08:32 & 03/21/2007 10:33 & 02:01 & .07 & .12 & .08 & .05 & 220 & 00 02:47 \\
\hline 34 & 03/21/2007 17:39 & 03/21/2007 18:37 & 00:58 & .12 & .24 & .14 & .16 & 370 & 00 07:06 \\
\hline 34 & 03/22/2007 01:24 & 03/22/2007 03:14 & 01:50 & .54 & 1.16 & .82 & 4.1 & 1,670 & 00 06:47 \\
\hline 34 & 03/28/2007 12:36 & 03/28/2007 14:40 & 02:04 & .09 & .16 & .10 & .08 & 280 & 06 09:22 \\
\hline 35 & 03/31/2007 08:31 & 03/31/2007 09:14 & $00: 43$ & .09 & .28 & .16 & .12 & 280 & 02 17:51 \\
\hline 35 & 03/31/2007 12:10 & 03/31/2007 14:10 & 02:00 & .35 & .64 & .34 & 1.1 & 1,080 & 00 02:56 \\
\hline 35 & 03/31/2007 20:37 & 03/31/2007 22:48 & 02:11 & .60 & .68 & .54 & 2.9 & 1,850 & 00 06:27 \\
\hline 36 & 04/03/2007 00:03 & 04/03/2007 07:31 & 07:28 & 1.58 & 1.04 & .60 & 8.2 & 4,880 & 02 01:15 \\
\hline 36 & 04/11/2007 00:03 & 04/11/2007 06:50 & $06: 47$ & .20 & .08 & .08 & .14 & 620 & $0716: 32$ \\
\hline 36 & 04/12/2007 11:20 & 04/12/2007 14:38 & 03:18 & .18 & .12 & .08 & .13 & 560 & 01 04:30 \\
\hline 36 & 04/22/2007 20:07 & 04/22/2007 20:30 & $00: 23$ & .08 & .28 & -- & -- & 250 & 10 05:29 \\
\hline 37 & 04/23/2007 00:25 & 04/23/2007 05:48 & $05: 23$ & .49 & .40 & .32 & 1.4 & 1,510 & 00 03:55 \\
\hline 38 & 04/24/2007 13:23 & 04/24/2007 23:18 & 09:55 & .35 & .16 & .12 & .35 & 1,080 & 01 07:35 \\
\hline 38 & 04/25/2007 00:21 & 04/25/2007 04:43 & 04:22 & .27 & .12 & .10 & .23 & 830 & 00 01:03 \\
\hline 38 & 04/25/2007 20:20 & 04/25/2007 21:13 & $00: 53$ & .06 & .08 & .06 & .03 & 190 & 00 15:37 \\
\hline 38 & 04/25/2007 23:19 & 04/26/2007 00:59 & 01:40 & .06 & .08 & .06 & .03 & 190 & 00 02:06 \\
\hline 39 & 04/26/2007 08:57 & 04/26/2007 12:43 & 03:46 & .32 & .16 & .14 & .38 & 990 & 00 07:58 \\
\hline 39 & 04/30/2007 20:37 & 04/30/2007 20:56 & 00:19 & .08 & .28 & -- & -- & 250 & 04 07:54 \\
\hline 39 & 05/13/2007 05:41 & 05/13/2007 09:50 & 04:09 & .32 & .20 & .14 & .38 & 990 & 12 08:45 \\
\hline 40 & 05/15/2007 12:23 & 05/15/2007 16:06 & 03:43 & .59 & .56 & .48 & 2.4 & 1,820 & 02 02:33 \\
\hline 40 & 05/16/2007 16:56 & 05/16/2007 17:09 & $00: 13$ & .08 & -- & -- & -- & 250 & $0100: 50$ \\
\hline 41 & 05/24/2007 16:38 & 05/24/2007 18:24 & 01:46 & .49 & .84 & .70 & 3.2 & 1,510 & $0723: 29$ \\
\hline 41 & 05/26/2007 14:41 & 05/26/2007 15:09 & $00: 28$ & .06 & .20 & -- & -- & 190 & $0120: 17$ \\
\hline 41 & 06/01/2007 16:44 & 06/01/2007 17:30 & $00: 46$ & .20 & .64 & .38 & .71 & 620 & $0601: 35$ \\
\hline 41 & 06/02/2007 06:36 & 06/02/2007 08:13 & $01: 37$ & .23 & .40 & .28 & .55 & 710 & 00 13:06 \\
\hline
\end{tabular}


Table 2-3. Precipitation during sampling events from a stormwater-filtration device, Madison, Wis., 2005-07. —Continued [mm, month; dd, day; yyyy, year; hh, hour; mm, min, minute; in., inch; in/h, inch per hour; ft-lb/acre, foot per pound per acre; $\mathrm{ft}^{3}$, cubic foot]

\begin{tabular}{|c|c|c|c|c|c|c|c|c|c|}
\hline $\begin{array}{c}\text { Sampling } \\
\text { event } \\
\text { number }\end{array}$ & $\begin{array}{c}\text { Start date } \\
\text { and time } \\
\text { (mm/dd/yyyy } \\
\text { hh:mm) }\end{array}$ & $\begin{array}{c}\text { End date } \\
\text { and time } \\
\text { (mm/dd/yyyy } \\
\text { hh:mm) }\end{array}$ & $\begin{array}{l}\text { Precipi- } \\
\text { tation } \\
\text { duration } \\
\text { (hh:mm) }\end{array}$ & $\begin{array}{l}\text { Total } \\
\text { precipi- } \\
\text { tation } \\
\text { (in.) }\end{array}$ & $\begin{array}{c}\text { Max } \\
\text { 15-min } \\
\text { intensity } \\
\text { (in/h) }\end{array}$ & $\begin{array}{c}\text { Max } \\
\text { 30-min } \\
\text { intensity } \\
\text { (in/h) }\end{array}$ & $\begin{array}{l}\text { Erosivity } \\
\text { index } \\
\text { (hundreds } \\
\text { of } \mathrm{ft}-\mathrm{lb} / \\
\mathrm{acre} / \mathrm{in} / \mathrm{hr} \text { ) }\end{array}$ & $\begin{array}{l}\text { Precipitation } \\
\text { volume } \\
\left(\mathrm{ft}^{3}\right)\end{array}$ & $\begin{array}{c}\text { Antecedent } \\
\text { dry times } \\
\text { (dd hh:mm) }\end{array}$ \\
\hline 41 & 06/03/2007 16:56 & 06/03/2007 19:42 & $02: 46$ & 0.70 & 1.12 & 0.66 & 4.3 & 2,160 & $0108: 43$ \\
\hline 41 & 06/03/2007 20:55 & 06/03/2007 22:50 & 01:55 & .36 & .56 & .36 & 1.1 & 1,110 & $0001: 13$ \\
\hline 41 & 06/04/2007 06:00 & 06/04/2007 07:48 & 01:48 & .27 & .28 & .20 & .46 & 830 & 00 07:10 \\
\hline 41 & 06/04/2007 08:56 & 06/04/2007 09:56 & 01:00 & .14 & .48 & .26 & .32 & 430 & 00 01:08 \\
\hline 41 & 06/06/2007 15:02 & 06/06/2007 17:12 & 02:10 & .06 & .08 & .04 & .02 & 190 & 02 05:06 \\
\hline 41 & 06/11/2007 09:10 & 06/11/2007 09:49 & 00:39 & 1.21 & 2.08 & 2.02 & 25 & 3,730 & 04 15:58 \\
\hline 41 & 06/18/2007 15:46 & 06/18/2007 16:14 & 00:28 & .09 & .24 & -- & -- & 280 & 07 05:57 \\
\hline 41 & 06/18/2007 18:44 & 06/18/2007 19:02 & 00:18 & .11 & .40 & -- & -- & 340 & 00 02:30 \\
\hline 41 & 06/21/2007 16:31 & 06/21/2007 17:16 & 00:45 & .06 & .20 & .10 & .06 & 190 & $0221: 29$ \\
\hline 42 & 06/21/2007 18:23 & 06/21/2007 22:53 & 04:30 & .43 & .56 & .30 & 1.1 & 1,330 & 00 01:07 \\
\hline 43 & 07/03/2007 20:12 & 07/03/2007 23:31 & 03:19 & .47 & .32 & .28 & 1.1 & 1,450 & $1121: 19$ \\
\hline 44 & 07/26/2007 10:20 & 07/26/2007 10:28 & 00:08 & .12 & -- & -- & -- & 370 & 22 10:49 \\
\hline 44 & 07/26/2007 22:57 & 07/27/2007 01:20 & $02: 23$ & .53 & .68 & .56 & 2.6 & 1,640 & 00 12:29 \\
\hline 44 & 07/27/2007 07:07 & 07/27/2007 07:20 & 00:13 & .06 & -- & -- & -- & 190 & 00 05:47 \\
\hline 45 & 08/04/2007 17:01 & 08/04/2007 19:52 & 02:51 & .47 & .52 & .44 & 1.8 & 1,450 & 08 09:41 \\
\hline 45 & 08/04/2007 21:05 & 08/05/2007 05:10 & 08:05 & 1.31 & .88 & .68 & 7.6 & 4,040 & $0001: 13$ \\
\hline 46 & 08/06/2007 21:58 & 08/07/2007 05:55 & 07:57 & .60 & .20 & .12 & .17 & 1,850 & 01 16:48 \\
\hline 47 & 08/09/2007 04:09 & 08/09/2007 05:54 & 01:45 & .86 & 1.28 & .96 & 7.5 & 2,650 & $0122: 14$ \\
\hline 48 & 08/12/2007 00:58 & 08/12/2007 02:25 & $01: 27$ & .68 & 2.04 & 1.20 & 8.0 & 2,100 & 02 19:04 \\
\hline 49 & 08/14/2007 02:31 & 08/14/2007 05:09 & $02: 38$ & .56 & .44 & .40 & 1.7 & 1,710 & $0200: 06$ \\
\hline 50 & 08/15/2007 07:42 & 08/15/2007 12:58 & 05:16 & .35 & .24 & .20 & .26 & 1,080 & $0102: 33$ \\
\hline 51 & 08/18/2007 11:34 & 08/19/2007 12:16 & 00:42 & 4.93 & 1.96 & 1.64 & 68 & 15,210 & $0222: 36$ \\
\hline 51 & 08/22/2007 01:29 & 08/22/2007 03:47 & 02:18 & .28 & .47 & .27 & .64 & 860 & 02 13:13 \\
\hline 51 & 08/22/2007 15:55 & 08/22/2007 16:32 & 00:37 & .15 & .33 & .24 & .32 & 480 & 00 12:08 \\
\hline 51 & 08/22/2007 18:31 & 08/22/2007 21:19 & 02:48 & .40 & .47 & .36 & 1.2 & 1,220 & $0001: 59$ \\
\hline 51 & 08/23/2007 04:29 & 08/23/2007 05:11 & 00:42 & .07 & .14 & .13 & .08 & 220 & 00 07:10 \\
\hline 51 & 08/23/2007 07:02 & 08/23/2007 08:38 & $01: 36$ & .34 & .40 & .38 & 1.1 & 1,060 & $0001: 51$ \\
\hline 51 & 08/23/2007 17:34 & 08/23/2007 17:43 & 00:09 & .05 & -- & -- & -- & 170 & 00 08:56 \\
\hline 51 & 08/24/2007 02:49 & 08/24/2007 04:22 & $01: 33$ & .61 & 1.09 & .94 & 5.3 & 1,870 & 00 09:06 \\
\hline 51 & 08/24/2007 16:15 & 08/24/2007 16:53 & $00: 38$ & .73 & 1.87 & 1.37 & 9.8 & 2,250 & $0011: 53$ \\
\hline 51 & 08/27/2007 08:57 & 08/27/2007 11:41 & 02:44 & .50 & .47 & .32 & 1.4 & 1,560 & $0216: 04$ \\
\hline
\end{tabular}


Table 2-4. Outlet flow volumes, percent runoff, and peak discharge for sampled events at a stormwater-filtration device, Madison, Wis., 2005-07.

[mm, month; dd, day; yyyy, year; hh, hour; mm, minute; in., inch; $\mathrm{ft}^{3}$, cubic foot; $\mathrm{ft}^{3} / \mathrm{s}$, cubic foot per second]

\begin{tabular}{|c|c|c|c|c|c|c|}
\hline $\begin{array}{l}\text { Sampling } \\
\text { event } \\
\text { number }\end{array}$ & $\begin{array}{c}\text { Start date } \\
\text { and time } \\
\text { (mm/dd/yyyy } \\
\text { hh:mm) }\end{array}$ & $\begin{array}{c}\text { End date } \\
\text { and time } \\
\text { (mm/dd/yyyy } \\
\text { hh:mm) }\end{array}$ & $\begin{array}{c}\text { Total } \\
\text { precipitation } \\
\text { (in.) }\end{array}$ & $\begin{array}{c}\text { Volume } \\
\left(\mathrm{ft}^{3}\right)\end{array}$ & $\begin{array}{c}\text { Percent } \\
\text { runoff }\end{array}$ & $\begin{array}{c}\text { Peak } \\
\text { discharge } \\
\left(\mathrm{ft}^{3} / \mathrm{s}\right)\end{array}$ \\
\hline 1 & $11 / 05 / 2005$ 17:40 & $11 / 06 / 2005$ 00:39 & 1.01 & 2,015 & 60 & 0.42 \\
\hline 2 & $11 / 15 / 200513: 38$ & $11 / 15 / 200520: 51$ & .77 & 1,640 & 64 & .51 \\
\hline 3 & 11/28/2005 03:18 & 11/28/2005 08:09 & .63 & 1,165 & 55 & .70 \\
\hline 4 & 03/08/2006 18:08 & 03/08/2006 22:58 & .85 & 2,240 & 79 & .09 \\
\hline 5 & 04/02/2006 11:19 & 04/02/2006 13:36 & .25 & 380 & 46 & .49 \\
\hline 6 & 04/02/2006 20:45 & 04/03/2006 06:15 & 1.09 & 2,555 & 70 & .88 \\
\hline 7 & 04/06/2006 10:22 & 04/07/2006 08:56 & 1.61 & 3,930 & 73 & .49 \\
\hline 8 & 04/12/2006 05:36 & 04/12/2006 07:48 & .44 & 685 & 46 & .84 \\
\hline 9 & 04/16/2006 04:17 & 04/16/2006 17:10 & .95 & 2,125 & 67 & .10 \\
\hline 10 & 04/29/2006 18:28 & 04/29/2006 23:41 & .33 & 630 & 57 & .99 \\
\hline 11 & 05/01/2006 21:09 & $05 / 01 / 200622: 35$ & .41 & 1,045 & 76 & .42 \\
\hline 12 & 05/09/2006 14:26 & 05/09/2006 17:29 & .41 & 770 & 57 & .07 \\
\hline 13 & 05/11/2006 13:32 & 05/12/2006 06:38 & .62 & 1,840 & 89 & .11 \\
\hline 14 & 05/16/2006 15:23 & 05/16/2006 18:52 & .19 & 335 & 53 & .77 \\
\hline 15 & 05/17/2006 15:30 & 05/17/2006 17:01 & .36 & 845 & 70 & .51 \\
\hline 16 & 06/10/2006 00:58 & 06/10/2006 07:23 & .69 & 985 & 43 & .67 \\
\hline 17 & $06 / 25 / 2006$ 17:57 & $06 / 26 / 200609: 37$ & .45 & 1,600 & 106 & .85 \\
\hline 18 & 07/11/2006 08:48 & 07/11/2006 15:39 & 1.87 & 6,040 & 97 & .80 \\
\hline 19 & 07/20/2006 02:48 & 07/20/2006 07:44 & .88 & 1,850 & 63 & .60 \\
\hline 20 & 08/06/2006 07:21 & 08/06/2006 11:29 & .87 & 1,020 & 35 & .68 \\
\hline 21 & 08/09/2006 18:49 & 08/09/2006 19:19 & .21 & 240 & 35 & .71 \\
\hline 22 & 08/17/2006 16:42 & 08/17/2006 17:23 & .22 & 275 & 38 & .86 \\
\hline 23 & 08/23/2006 22:50 & 08/24/2006 07:47 & 1.51 & 2,680 & 53 & .85 \\
\hline 24 & 08/24/2006 13:11 & 08/24/2006 15:24 & 1.22 & 1,995 & 49 & 1.05 \\
\hline 25 & 08/25/2006 10:57 & 08/25/2006 13:54 & 1.14 & 1,765 & 46 & .07 \\
\hline 26 & 09/03/2006 18:38 & 09/04/2006 08:58 & .59 & 475 & 24 & .73 \\
\hline 27 & 10/04/2006 06:11 & $10 / 04 / 200610: 56$ & .33 & 620 & 56 & .45 \\
\hline 28 & $10 / 16 / 200623: 28$ & 10/17/2006 07:32 & .75 & 2,110 & 84 & .06 \\
\hline 29 & 10/21/2006 13:08 & $10 / 22 / 200601: 48$ & .58 & 1,020 & 53 & .59 \\
\hline 30 & $11 / 10 / 200612: 28$ & $11 / 10 / 200614: 54$ & .55 & 590 & 32 & .08 \\
\hline 31 & $11 / 26 / 200623: 12$ & $11 / 27 / 200602: 05$ & .21 & 300 & 43 & .71 \\
\hline 32 & 11/27/2006 20:18 & 11/28/2006 08:19 & .76 & 2,340 & 92 & .49 \\
\hline 33 & $12 / 21 / 200607: 50$ & $12 / 21 / 200613: 43$ & .47 & 1,165 & 74 & .71 \\
\hline 34 & $12 / 22 / 200614: 00$ & $12 / 22 / 200615: 34$ & .23 & 615 & 80 & .79 \\
\hline 35 & 03/31/2007 08:46 & 03/31/2007 23:20 & 1.04 & 2,585 & 74 & .87 \\
\hline
\end{tabular}


Table 2-4. Outlet flow volumes, percent runoff, and peak discharge for sampled events at a stormwater-filtration device, Madison, Wis., 2005-07. - Continued

[mm, month; dd, day; yyyy, year; hh, hour; mm, minute; in., inch; $\mathrm{ft}^{3}$, cubic foot; $\mathrm{ft}^{3} / \mathrm{s}$, cubic foot per second]

\begin{tabular}{ccccccc}
\hline $\begin{array}{c}\text { Sampling } \\
\text { event } \\
\text { number }\end{array}$ & $\begin{array}{c}\text { Start date } \\
\text { and time } \\
\text { (mm/dd/yyyy } \\
\text { hh:mm) }\end{array}$ & $\begin{array}{c}\text { End date } \\
\text { and time } \\
\text { (mm/dd/yyyy } \\
\text { hh:mm) }\end{array}$ & $\begin{array}{c}\text { Total } \\
\text { precipitation } \\
\text { (in.) }\end{array}$ & $\begin{array}{c}\text { Volume } \\
\left.\text { (ft } \mathbf{t}^{3}\right)\end{array}$ & $\begin{array}{c}\text { Percent } \\
\text { runoff }\end{array}$ & $\begin{array}{c}\text { Peak } \\
\text { discharge } \\
\text { (ft/s) }\end{array}$ \\
\hline 36 & $04 / 03 / 200700: 13$ & $04 / 03 / 200707: 51$ & 1.58 & 4,085 & 77 & 0.67 \\
37 & $04 / 23 / 200700: 54$ & $04 / 23 / 200707: 10$ & .49 & 1,035 & 63 & .05 \\
38 & $04 / 24 / 200717: 27$ & $04 / 24 / 200719: 44$ & .35 & 235 & 20 & .08 \\
39 & $04 / 26 / 200709: 37$ & $04 / 26 / 200713: 05$ & .32 & 665 & 62 & .66 \\
40 & $05 / 15 / 200712: 39$ & $05 / 15 / 200717: 49$ & .59 & 1,235 & 63 & .73 \\
41 & $05 / 24 / 200716: 43$ & $05 / 24 / 200718: 47$ & .49 & 830 & 51 & .69 \\
42 & $06 / 21 / 200719: 01$ & $06 / 21 / 200723: 09$ & .43 & 560 & 39 & .39 \\
43 & $07 / 03 / 200720: 54$ & $07 / 03 / 200723: 33$ & .47 & 590 & 37 & .68 \\
44 & $07 / 26 / 200710: 28$ & $07 / 27 / 200701: 43$ & .65 & 1,185 & 55 & .84 \\
45 & $08 / 04 / 200717: 30$ & $08 / 05 / 200707: 44$ & 1.78 & 4,070 & 68 & .76 \\
46 & $08 / 06 / 200722: 35$ & $08 / 07 / 200706: 33$ & .60 & 1,805 & 90 & .92 \\
47 & $08 / 09 / 200703: 13$ & $08 / 09 / 200707: 14$ & .86 & 2,755 & 96 & .81 \\
48 & $08 / 12 / 200701: 04$ & $08 / 12 / 200702: 48$ & .68 & 840 & 37 & .88 \\
49 & $08 / 14 / 200702: 43$ & $08 / 14 / 200707: 03$ & .56 & 1,980 & 107 & .10 \\
50 & $08 / 15 / 200708: 15$ & $08 / 15 / 200714: 32$ & .35 & 690 & 59 & 1.01 \\
51 & $08 / 18 / 200714: 21$ & $08 / 19 / 200713: 01$ & 4.93 & 8,210 & 50 & 42 \\
\hline
\end{tabular}


Table 2-5. Concentrations of suspended solids, suspended sediment, volatile solids, and dissolved solids in stormwater samples collected from a stormwater-filtration device, Madison, Wis., 2005-07.

[All data are in milligrams per liter; --, no sample processed for event; $<$, less than]

\begin{tabular}{|c|c|c|c|c|c|c|c|c|}
\hline \multirow{2}{*}{$\begin{array}{c}\text { Sampling } \\
\text { event } \\
\text { number }\end{array}$} & \multicolumn{2}{|c|}{ Suspended solids, total } & \multicolumn{2}{|c|}{ Suspended sediment } & \multicolumn{2}{|c|}{ Solids, volatile } & \multicolumn{2}{|c|}{ Solids, dissolved } \\
\hline & Inlet & Outlet & Inlet & Outlet & Inlet & Outlet & Inlet & Outlet \\
\hline 1 & 14 & 8 & 22 & 7 & -- & -- & $<50$ & $<50$ \\
\hline 2 & 10 & 7 & 18.2 & 6 & -- & -- & $<50$ & $<50$ \\
\hline 3 & 42 & 27 & 53 & 26 & -- & -- & 94 & 96 \\
\hline 4 & 37 & 45 & 41 & 47 & -- & -- & 58 & 80 \\
\hline 5 & 34 & 13 & 34 & 14 & -- & -- & 66 & 82 \\
\hline 6 & 13 & 13 & 15 & 12 & -- & -- & $<50$ & $<50$ \\
\hline 7 & 68 & 45 & 75 & 45 & 15 & 11 & $<50$ & $<50$ \\
\hline 8 & 26 & 26 & 35 & 25 & 8 & 7 & $<50$ & $<50$ \\
\hline 9 & 35 & 20 & 45 & 20 & 10 & 6 & $<50$ & $<50$ \\
\hline 10 & 14 & 12 & 14 & 12 & 6 & 5 & $<50$ & $<50$ \\
\hline 11 & 42 & 25 & 46 & 25 & 13 & 8 & $<50$ & $<50$ \\
\hline 12 & 191 & 3 & 14 & 3 & 19 & 2 & $<50$ & $<50$ \\
\hline 13 & 5 & 2 & 6 & 2 & 4 & $<2$ & $<50$ & $<50$ \\
\hline 14 & 80 & 12 & 82 & 12 & -- & -- & $<50$ & $<50$ \\
\hline 15 & 102 & 34 & 77 & 30 & 55 & 15 & -- & -- \\
\hline 16 & 13 & 8 & 21 & 7 & 5 & 3 & $<50$ & $<50$ \\
\hline 17 & 14 & 8 & 22 & 7 & 5 & 3 & $<50$ & $<50$ \\
\hline 18 & 8 & 6 & 14 & 5 & 3 & 2 & $<50$ & $<50$ \\
\hline 19 & 24 & 19 & 31 & 15 & 8 & 6 & $<50$ & $<50$ \\
\hline 20 & 8 & 4 & 7 & 3 & 3 & $<2$ & $<50$ & $<50$ \\
\hline 21 & 41 & 33 & 42 & 33 & -- & -- & $<50$ & 50 \\
\hline 22 & 17 & 16 & 17 & 14 & -- & -- & $<50$ & $<50$ \\
\hline 23 & 23 & 17 & 32 & 9 & 7 & 5 & $<50$ & $<50$ \\
\hline 24 & 20 & 7 & 19 & 6 & 6 & -- & $<50$ & $<50$ \\
\hline 25 & 15 & 16 & 12 & 11 & 8 & 5 & $<50$ & $<50$ \\
\hline 26 & $<2$ & 4 & 9 & 4 & -- & -- & $<100$ & $<50$ \\
\hline 27 & 26 & 24 & 26 & 23 & 10 & 8 & $<50$ & $<50$ \\
\hline 28 & 5 & 5 & 4 & 5 & 3 & 2 & $<50$ & $<50$ \\
\hline 29 & $<2$ & $<2$ & 2 & 1.9 & -- & -- & $<50$ & $<50$ \\
\hline 30 & 11 & 7 & 36 & 6 & -- & -- & $<50$ & $<50$ \\
\hline 31 & 8 & 4 & 8 & 4 & -- & -- & $<50$ & $<50$ \\
\hline 32 & 6 & 5 & 6 & 4 & 3 & 2 & $<50$ & $<50$ \\
\hline 33 & 20 & 15 & 20 & 13 & 8 & 6 & 52 & 56 \\
\hline 34 & 40 & 38 & 38 & 38 & 17 & 18 & $<50$ & $<50$ \\
\hline 35 & 66 & 50 & 76 & 62 & 16 & 23 & $<50$ & $<50$ \\
\hline 36 & 15 & 14 & 22 & 16 & 5 & 4 & $<50$ & $<50$ \\
\hline
\end{tabular}


Table 2-5. Concentrations of suspended solids, suspended sediment, volatile solids, and dissolved solids in stormwater samples collected from a stormwater-filtration device, Madison, Wis., 2005-07. —Continued

[All data are in milligrams per liter; --, no sample processed for event; $<$, less than]

\begin{tabular}{|c|c|c|c|c|c|c|c|c|}
\hline \multirow{2}{*}{$\begin{array}{l}\text { Sampling } \\
\text { event } \\
\text { number }\end{array}$} & \multicolumn{2}{|c|}{ Suspended solids, total } & \multicolumn{2}{|c|}{ Suspended sediment } & \multicolumn{2}{|c|}{ Solids, volatile } & \multicolumn{2}{|c|}{ Solids, dissolved } \\
\hline & Inlet & Outlet & Inlet & Outlet & Inlet & Outlet & Inlet & Outlet \\
\hline 37 & 18 & 22 & 19 & 23 & 8 & 6 & $<50$ & $<50$ \\
\hline 38 & 4 & $<2$ & 4 & 3 & $<2$ & $<2$ & $<50$ & $<50$ \\
\hline 39 & 3 & 2 & 4 & 3 & -- & -- & $<50$ & $<50$ \\
\hline 40 & 18 & 12 & 18 & 10 & 7 & 4 & $<50$ & $<50$ \\
\hline 41 & 40 & 23 & 44 & 26 & 14 & 8 & $<50$ & $<50$ \\
\hline 42 & -- & -- & -- & -- & -- & -- & -- & -- \\
\hline 43 & 10 & 5 & 10 & 5 & 4 & 2 & $<50$ & $<50$ \\
\hline 44 & 15 & 13 & 12 & 10 & 7 & 5 & $<50$ & 52 \\
\hline 45 & 6 & 7 & 7 & 5 & 7 & 5 & $<50$ & $<50$ \\
\hline 46 & -- & -- & 9 & 5 & -- & -- & -- & -- \\
\hline 47 & -- & -- & 5 & 5 & -- & -- & -- & -- \\
\hline 48 & -- & -- & 13 & 9 & -- & -- & -- & -- \\
\hline 49 & -- & -- & 7 & 7 & -- & -- & -- & -- \\
\hline 50 & -- & -- & 5 & 3 & -- & -- & -- & -- \\
\hline 51 & -- & -- & 5 & 7 & -- & -- & -- & -- \\
\hline
\end{tabular}


Table 2-6. Concentrations of selected constituents and physical properties in stormwater samples collected from a stormwater-filtration device, Madison, Wis., $2005-07$.

[mg/L, milligrams per liter; $\mu \mathrm{g} / \mathrm{L}$, micrograms per liter; $<$, less than; --, no sample processed for event]

\begin{tabular}{|c|c|c|c|c|c|c|c|c|c|c|c|c|c|c|c|c|c|c|c|c|}
\hline \multirow[t]{2}{*}{$\begin{array}{c}\text { Sampling } \\
\text { event } \\
\text { number }\end{array}$} & \multicolumn{2}{|c|}{$\begin{array}{c}\text { Chemical } \\
\text { oxygen } \\
\text { demand, } \\
\text { total } \\
\text { (mg/L) }\end{array}$} & \multicolumn{2}{|c|}{$\begin{array}{c}\text { Phosphorus, } \\
\text { total } \\
\text { (mg/L) }\end{array}$} & \multicolumn{2}{|c|}{$\begin{array}{l}\text { Phosphorus, } \\
\text { dissolved } \\
\text { (mg/L) }\end{array}$} & \multicolumn{2}{|c|}{$\begin{array}{c}\text { Chloride, } \\
\text { dissolved } \\
\text { (mg/L) }\end{array}$} & \multicolumn{2}{|c|}{$\begin{array}{c}\text { Copper, } \\
\text { dissolved } \\
(\mu \mathrm{g} / \mathrm{L})\end{array}$} & \multicolumn{2}{|c|}{$\begin{array}{c}\text { Copper, } \\
\text { total } \\
\text { recoverable } \\
(\mu \mathrm{g} / \mathrm{L})\end{array}$} & \multicolumn{2}{|c|}{$\begin{array}{c}\text { Zinc, } \\
\text { dissolved } \\
(\mu \mathrm{g} / \mathrm{L})\end{array}$} & \multicolumn{2}{|c|}{$\begin{array}{c}\text { Zinc, } \\
\text { total } \\
\text { recoverable } \\
(\mu \mathrm{g} / \mathrm{L})\end{array}$} & \multicolumn{2}{|c|}{$\begin{array}{l}\text { Calcium, } \\
\text { total } \\
\text { recoverable } \\
\text { (mg/L) }\end{array}$} & \multicolumn{2}{|c|}{$\begin{array}{c}\text { Magnesium, } \\
\text { total } \\
\text { recoverable } \\
(\mathrm{mg} / \mathrm{L})\end{array}$} \\
\hline & Inlet & Outlet & Inlet & Outlet & Inlet & Outlet & Inlet & Outlet & Inlet & Outlet & Inlet & Outlet & Inlet & Outlet & Inlet & Outlet & Inlet & Outlet & Inlet & Outlet \\
\hline 1 & $<9$ & 15 & 0.09 & 0.08 & 0.061 & 0.06 & 1.7 & 2 & 1.8 & 1.9 & 3.0 & 3.0 & $<16$ & $<16$ & $<16$ & $<16$ & 4.2 & 4.2 & 1.3 & 0.9 \\
\hline 2 & 22 & 16 & .08 & .07 & .05 & .04 & 2.1 & 2.6 & $<1.0$ & $<1.0$ & 2 & 3 & -- & -- & 18 & 18 & 3.2 & 3.4 & .90 & .80 \\
\hline 3 & -- & -- & -- & -- & -- & -- & 39 & 41 & -- & -- & -- & -- & -- & -- & -- & -- & -- & -- & -- & -- \\
\hline 4 & -- & -- & -- & -- & -- & -- & 17 & 29 & -- & -- & -- & -- & -- & -- & -- & -- & -- & -- & -- & -- \\
\hline 5 & -- & -- & -- & -- & -- & -- & 18 & 24 & -- & -- & -- & -- & -- & -- & -- & -- & -- & -- & -- & -- \\
\hline 6 & 8.8 & 43.4 & .03 & .03 & .09 & .02 & 3.8 & 3.9 & 1.9 & 1.7 & 4 & 3 & -- & -- & 17 & 18 & 3.6 & 3.4 & 1.0 & .80 \\
\hline 7 & 52 & 29 & .09 & .07 & .02 & .02 & 2.5 & 2.3 & 1.8 & 1.6 & 7 & 6 & 8 & 10 & 44 & 37 & 8.3 & 5.7 & 3.5 & 2.2 \\
\hline 8 & 24 & 22 & 2.0 & .05 & .02 & .02 & 4.3 & 4.6 & 2.7 & 2.4 & 5 & 4 & 6 & 11 & 23 & 25 & 5.5 & 5.1 & 1.7 & 1.4 \\
\hline 9 & 26 & 13 & .06 & .04 & .02 & .01 & 1.8 & 1.9 & $<1.0$ & 1.0 & 4 & 3 & 6 & 11 & 43 & 20 & 8.6 & 3.5 & 2.2 & 1.1 \\
\hline 10 & 13 & 16 & .05 & .04 & .02 & .02 & 1.5 & 2.3 & $<1.0$ & $<1.0$ & 2 & 2 & 8 & 14 & 18 & 22 & 4.2 & 4.5 & 1.1 & 1.0 \\
\hline 11 & $<9.0$ & 17 & .02 & .05 & .07 & .02 & 1.3 & 1.3 & $<1.0$ & $<1.0$ & 3 & 2 & 6 & 9 & 25 & 22 & 4.9 & 3.1 & 2.0 & 1.1 \\
\hline 12 & 24 & 16 & .06 & .04 & .03 & .03 & 1.8 & 2.2 & 2.5 & 2.6 & 4 & 4 & 8 & 11 & 19 & 14 & 4.4 & 3.9 & 1.1 & .80 \\
\hline 13 & $<9.0$ & 14 & .06 & .04 & .04 & .03 & -- & 1.9 & 4.0 & 2.3 & 3 & 3 & 12 & 13 & 13 & 15 & 3.4 & 4.3 & .70 & .90 \\
\hline 14 & -- & -- & -- & -- & -- & -- & 4.1 & 4.5 & -- & -- & -- & -- & -- & -- & -- & -- & -- & -- & -- & -- \\
\hline 15 & 48 & 36 & .11 & .09 & .04 & .03 & 1.9 & -- & 2.1 & 2.0 & 7 & 5 & 8 & 9 & 37 & 31 & 5.3 & 4.0 & 2.2 & 1.4 \\
\hline 16 & 22 & 14 & .06 & .07 & .04 & .05 & 1.4 & 1.6 & 3.0 & 3.0 & 4 & 4 & 6 & 9 & 17 & 19 & 4.1 & 5.5 & 1.2 & 1.3 \\
\hline 17 & 13 & 12 & .05 & .06 & .03 & .02 & 1.3 & 1.4 & 1.9 & 2.2 & 8 & 3 & 6 & 11 & 20 & 16 & 4.1 & 4.0 & 1.2 & 1.0 \\
\hline 18 & $<9.0$ & $<9.0$ & .03 & .03 & .02 & .02 & 1.0 & 1.0 & 3.7 & 2.5 & 6 & 5 & 8 & 8 & 14 & 13 & 2.6 & 2.6 & .80 & .70 \\
\hline 19 & 32 & 15 & .08 & .07 & .05 & .05 & 1.1 & 1.2 & 2.6 & 2.5 & 13 & 5 & 8 & 9 & 33 & 21 & 4.6 & 3.5 & 1.6 & 1.0 \\
\hline 20 & 10 & 13 & .04 & .05 & .03 & .04 & 1.1 & 1.3 & $<2.0$ & $<2.0$ & 3 & 3 & 9 & 9 & 16 & 15 & 3.4 & 3.7 & .90 & .90 \\
\hline 21 & -- & -- & -- & -- & -- & -- & 2.1 & 2.5 & -- & -- & -- & -- & -- & -- & -- & -- & -- & -- & -- & -- \\
\hline 22 & -- & -- & -- & -- & -- & -- & 1.1 & 1.7 & -- & -- & -- & -- & -- & -- & -- & -- & -- & -- & -- & -- \\
\hline 23 & 28 & 33 & .05 & .04 & .03 & .03 & .80 & -- & $<2.0$ & $<2.0$ & 4 & 3 & 8 & 10 & 27 & 19 & 3.9 & 3.4 & 1.2 & .80 \\
\hline 24 & 15 & -- & .03 & .03 & .02 & .02 & .80 & .90 & $<2.0$ & $<2.0$ & 3 & 2 & 9 & 9 & 20 & 15 & 3.7 & 2.8 & 1.1 & .70 \\
\hline
\end{tabular}


Table 2-6. Concentrations of selected constituents and physical properties in stormwater samples collected from a stormwater-filtration device, Madison, Wis., 2005-07. - Continued

[mg/L, milligrams per liter; $\mu \mathrm{g} / \mathrm{L}$, micrograms per liter; <, less than; --, no sample processed for event]

\begin{tabular}{|c|c|c|c|c|c|c|c|c|c|c|c|c|c|c|c|c|c|c|c|c|}
\hline \multirow[t]{2}{*}{$\begin{array}{c}\text { Sampling } \\
\text { event } \\
\text { number }\end{array}$} & \multicolumn{2}{|c|}{$\begin{array}{c}\text { Chemical } \\
\text { oxygen } \\
\text { demand, } \\
\text { total } \\
\text { (mg/L) }\end{array}$} & \multicolumn{2}{|c|}{$\begin{array}{c}\text { Phosphorus, } \\
\text { total } \\
\text { (mg/L) }\end{array}$} & \multicolumn{2}{|c|}{$\begin{array}{l}\text { Phosphorus, } \\
\text { dissolved } \\
\text { (mg/L) }\end{array}$} & \multicolumn{2}{|c|}{$\begin{array}{c}\text { Chloride, } \\
\text { dissolved } \\
\text { (mg/L) }\end{array}$} & \multicolumn{2}{|c|}{$\begin{array}{c}\text { Copper, } \\
\text { dissolved } \\
(\mu \mathrm{g} / \mathrm{L})\end{array}$} & \multicolumn{2}{|c|}{$\begin{array}{c}\text { Copper, } \\
\text { total } \\
\text { recoverable } \\
(\mu \mathrm{g} / \mathrm{L})\end{array}$} & \multicolumn{2}{|c|}{$\begin{array}{c}\text { Zinc, } \\
\text { dissolved } \\
\text { ( } \mu \mathrm{g} / \mathrm{L})\end{array}$} & \multicolumn{2}{|c|}{$\begin{array}{c}\text { Zinc, } \\
\text { total } \\
\text { recoverable } \\
(\mu \mathrm{g} / \mathrm{L})\end{array}$} & \multicolumn{2}{|c|}{$\begin{array}{c}\text { Calcium, } \\
\text { total } \\
\text { recoverable } \\
(\mathrm{mg} / \mathrm{L})\end{array}$} & \multicolumn{2}{|c|}{$\begin{array}{c}\text { Magnesium, } \\
\text { total } \\
\text { recoverable } \\
(\mathrm{mg} / \mathrm{L})\end{array}$} \\
\hline & Inlet & Outlet & Inlet & Outlet & Inlet & Outlet & Inlet & Outlet & Inlet & Outlet & Inlet & Outlet & Inlet & Outlet & Inlet & Outlet & Inlet & Outlet & Inlet & Outlet \\
\hline 25 & 13 & 19 & 0.02 & 0.02 & 0.01 & $<0.005$ & 0.80 & 0.90 & $<2.0$ & $<2.0$ & 3 & 3 & 11 & 11 & 18 & 20 & 2.9 & 3.0 & 0.90 & 0.90 \\
\hline 26 & -- & -- & -- & -- & -- & -- & -- & 2.0 & -- & -- & -- & -- & -- & -- & -- & -- & -- & -- & -- & -- \\
\hline 27 & 41 & 36 & .10 & .08 & .06 & .05 & 1.4 & 1.7 & 2.0 & 3.0 & 7.0 & 5 & 9 & 14 & 33 & 30 & 5.2 & 7.0 & 1.7 & 2.0 \\
\hline 28 & $<9.0$ & $<9.0$ & .04 & .04 & .03 & .03 & .80 & .80 & $<2.0$ & $<2.0$ & $<2.0$ & $<2.0$ & 4.0 & 8.0 & 10 & 14 & 2.9 & 3.2 & .80 & .80 \\
\hline 29 & -- & -- & -- & -- & -- & -- & .90 & .90 & -- & -- & -- & -- & -- & -- & -- & -- & -- & -- & -- & -- \\
\hline 30 & -- & -- & -- & -- & -- & -- & 1.2 & 1.1 & -- & -- & -- & -- & -- & -- & -- & -- & -- & -- & -- & -- \\
\hline 32 & 24 & 14 & .02 & .03 & .02 & .01 & .90 & 1.1 & $<2.0$ & $<2.0$ & $<2.0$ & $<2.0$ & 8 & 13 & 14 & 17 & 3.5 & 4.0 & .90 & 1.0 \\
\hline 33 & 18 & 16 & .05 & .04 & .02 & .02 & 20 & 18 & $<2.0$ & $<2.0$ & 5.0 & 4.0 & 10 & 16 & 31 & 30 & 5.0 & 4.6 & 1.6 & 1.3 \\
\hline 34 & -- & -- & -- & -- & -- & -- & 8.8 & 10 & -- & -- & -- & -- & -- & -- & -- & -- & -- & -- & -- & -- \\
\hline 35 & 46 & 34 & .08 & .08 & .02 & .02 & 2.9 & 4.3 & $<2.0$ & $<2.0$ & 8 & 7 & 10 & 14 & 51 & 54 & 8.5 & 7.1 & 4.0 & 2.9 \\
\hline 36 & 12 & 13 & .03 & .03 & .01 & .01 & 1.9 & 2.2 & $<2.0$ & $<2.0$ & 3 & 2 & 7 & 10 & 19 & 22 & 3.3 & 3.3 & 1.3 & 1.0 \\
\hline 37 & 15 & 13 & .05 & .05 & .02 & .03 & -- & 3.4 & $<2.0$ & $<2.0$ & 4 & 4 & 6 & 11 & 22 & 29 & 4.2 & 5.7 & 1.2 & 1.7 \\
\hline 38 & $<9.0$ & $<9.0$ & .02 & .02 & .02 & .02 & 2.3 & 2.7 & $<2.0$ & $<2.0$ & 2 & 3 & 5 & 13 & 11 & 19 & 4.3 & 5.1 & 1.0 & 1.2 \\
\hline 40 & 26 & 24 & .07 & .08 & .03 & .03 & 2.2 & 2.3 & 4.0 & 4.0 & 5 & 3 & 11 & 17 & 27 & 28 & 4.9 & 5.5 & 1.5 & 1.5 \\
\hline 41 & 46 & 31 & .12 & .11 & .05 & .04 & 2.9 & 3.6 & 4.0 & 5.0 & 8 & 8 & 14 & 19 & 40 & 41 & 6.3 & 6.7 & 2.2 & 2.0 \\
\hline 43 & 33 & 36 & .06 & .07 & .04 & .04 & 1.2 & 1.3 & 2.0 & 2.0 & 4 & 3 & 8 & 13 & 19 & 19 & 4.0 & 6.0 & 1.1 & 1.5 \\
\hline 44 & 44 & 58 & .07 & .08 & .05 & .04 & 1.9 & 2.1 & 4.0 & 3.0 & 6 & 4 & 22 & 20 & 33 & 30 & 4.3 & 6.1 & 1.2 & 1.6 \\
\hline
\end{tabular}


Table 2-7. Mean concentrations of selected polycyclic aromatic hydrocarbons in samples collected from a stormwater-filtration device, Madison, Wis.,

[All concentrations in micrograms per liter; <, less than; --, no sample processed for event]

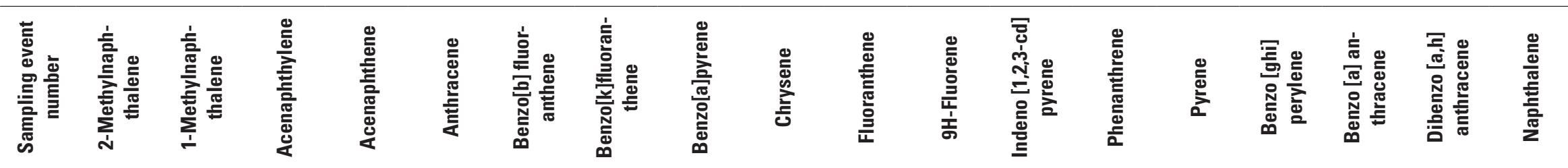

\begin{tabular}{|c|c|c|c|c|c|c|c|c|c|c|c|c|c|c|c|c|c|c|}
\hline \multicolumn{19}{|c|}{ Inlet } \\
\hline 10 & $<0.049$ & $<0.064$ & $<0.11$ & 0.08 & 0.25 & 5.2 & 2.4 & 2.8 & 4.6 & 13 & $<0.52$ & 3.8 & 5.8 & 9.2 & 4.0 & 1.2 & $<0.37$ & $<0.042$ \\
\hline 11 & $<.49$ & $<.64$ & $<1.1$ & $<.64$ & .97 & 18 & 8.2 & 12 & 17. & 47 & $<5.2$ & 13 & 26 & 36 & 14 & 5.0 & $<1.5$ & $<.42$ \\
\hline 13 & $<.049$ & $<.064$ & $<.11$ & $<.064$ & .05 & 1.7 & .68 & .66 & 1.4 & 3.7 & $<.52$ & 1.10 & 1.4 & 2.5 & 1.2 & .17 & $<.12$ & $<.042$ \\
\hline 16 & $<.049$ & $<.064$ & $<.11$ & $<.064$ & .19 & 4.0 & 1.7 & 1.8 & 3.6 & 11 & $<.52$ & 2.80 & 4.1 & 7.1 & 3.0 & $<.59$ & $<.28$ & $<.042$ \\
\hline 17 & $<.049$ & $<.064$ & $<.11$ & .16 & .32 & 5.2 & 2.3 & 1.9 & 4.8 & 15 & $<.52$ & 3.80 & 7.3 & 10 & 4.1 & $<1.0$ & $<.36$ & $<.042$ \\
\hline 18 & $<.049$ & $<.064$ & $<.11$ & $<.064$ & .14 & 3.4 & 1.5 & .78 & 3.1 & 8.9 & $<.52$ & 2.40 & 3.2 & 5.9 & 2.6 & $<.57$ & $<.23$ & $<.042$ \\
\hline 19 & $<.049$ & $<.064$ & $<.11$ & .09 & .36 & 7.5 & 3.6 & 4.1 & 7.0 & 19 & $<.52$ & 5.30 & 7.2 & 14 & 5.7 & 1.9 & $<.53$ & $<.042$ \\
\hline 23 & $<.049$ & $<.064$ & $<.11$ & $<.064$ & .30 & 8.1 & 3.7 & 5.5 & 7.1 & 18 & $<.52$ & 5.90 & 6.3 & 13 & 6.3 & 1.8 & $<.60$ & $<.042$ \\
\hline 24 & $<.049$ & $<.064$ & $<.11$ & $<.064$ & .24 & 5.4 & 2.5 & 3.9 & 4.7 & 12 & $<.52$ & 4.10 & 4.2 & 9.0 & 4.3 & 1.5 & $<.45$ & $<.042$ \\
\hline 25 & $<.049$ & $<.064$ & $<.11$ & $<.064$ & .29 & 4.8 & 2.2 & 3.6 & 4.3 & 11 & $<.52$ & 3.50 & 4.0 & 8.7 & 3.8 & 1.7 & $<.42$ & $<.042$ \\
\hline 37 & .11 & $<.064$ & $<.11$ & -- & .35 & 9.8 & 4.6 & 5.7 & 8.4 & 24 & $<.52$ & 5.80 & 11 & 17 & 7.1 & 1.7 & $<.79$ & $<.042$ \\
\hline 38 & $<.049$ & $<.064$ & $<.11$ & $<.064$ & .06 & 2.1 & 1.1 & .84 & 1.8 & 4.5 & $<.52$ & 1.20 & 1.9 & 3.1 & 1.4 & .34 & $<.14$ & $<.042$ \\
\hline 40 & .09 & $<.064$ & $<.11$ & .17 & .25 & 6.4 & 2.8 & 3.7 & 5.5 & 18 & $<.52$ & 3.60 & 6.6 & 11 & 4.4 & 1.1 & .47 & $<.042$ \\
\hline 41 & .09 & $<.064$ & $<.11$ & $<.064$ & $<.28$ & 10 & 4.8 & 6.1 & 8.8 & 25 & $<.52$ & 6.20 & 8.8 & 17 & 7.4 & 1.8 & $<.58$ & $<.042$ \\
\hline 43 & .09 & $<.064$ & $<.11$ & .11 & .25 & 3.8 & 1.8 & 2.4 & 3.6 & 11 & $<.52$ & 2.40 & 4.1 & 7.3 & 2.8 & .97 & $<.22$ & $<.042$ \\
\hline \multicolumn{19}{|c|}{ Outlet } \\
\hline 10 & $<.049$ & $<.064$ & $<.11$ & $<.064$ & .15 & 4.2 & 1.8 & 2.1 & 3.4 & 8.7 & $<.52$ & 3.0 & 4.4 & 6.6 & 3.2 & .57 & $<.31$ & $<.042$ \\
\hline 11 & $<.15$ & $<.2$ & $<.33$ & .24 & .49 & 11 & 4.8 & 6.4 & 9.5 & 25 & $<1.6$ & 7.6 & 13 & 19 & 8.4 & 2.5 & $<.80$ & $<.13$ \\
\hline 13 & $<.049$ & $<.064$ & $<.11$ & $<.064$ & $<.031$ & .91 & .36 & .33 & .62 & 1.6 & $<.52$ & .62 & .60 & .99 & .53 & $<.093$ & $<.078$ & $<.042$ \\
\hline 16 & $<.049$ & $<.064$ & $<.11$ & $<.064$ & .07 & 2.6 & 1.1 & .85 & 2.2 & 5.9 & $<.52$ & 1.8 & 2.7 & 4.0 & 1.9 & $<.24$ & $<.17$ & $<.042$ \\
\hline 17 & $<.049$ & $<.064$ & $<.11$ & $<.064$ & .04 & 2.3 & .93 & .42 & 2.0 & 5.2 & $<.52$ & 1.6 & 1.7 & 3.5 & 1.7 & $<.11$ & $<.14$ & $<.042$ \\
\hline 18 & $<.049$ & $<.064$ & $<.11$ & $<.064$ & .09 & 2.3 & .97 & .38 & 1.9 & 5.7 & $<.52$ & 1.6 & 2.1 & 3.7 & 1.7 & $<.40$ & $<.15$ & $<.042$ \\
\hline
\end{tabular}


Table 2-7. Mean concentrations of selected polycyclic aromatic hydrocarbons in samples collected from a stormwater-filtration device, Madison, Wis., 2005-07. - Continued

\begin{tabular}{|c|c|c|c|c|c|c|c|c|c|c|c|c|c|c|c|c|c|c|}
\hline 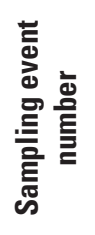 & 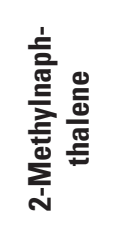 & 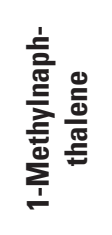 & 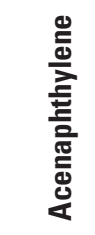 & 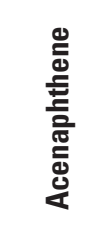 & 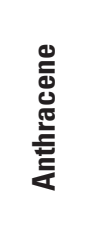 & 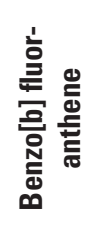 & 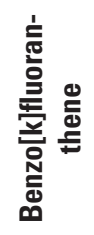 & 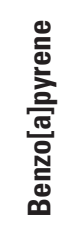 & 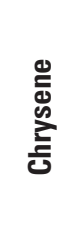 & 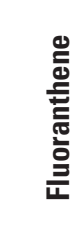 & $\begin{array}{l}\text { 흔 } \\
\text { 흠 } \\
\text { 퐇 }\end{array}$ & 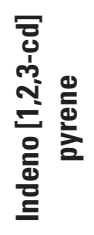 & 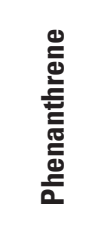 & さ્ّ & 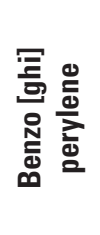 & 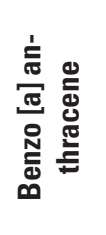 & 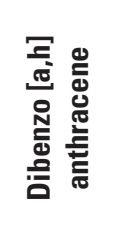 & $\begin{array}{l}\frac{0}{\bar{E}} \\
\frac{\bar{J}}{E} \\
\frac{E}{E} \\
\frac{\bar{J}}{Z}\end{array}$ \\
\hline \multicolumn{19}{|c|}{ Outlet-continued } \\
\hline 19 & $<0.049$ & $<0.064$ & $<0.11$ & $<0.064$ & 0.12 & 3.2 & 1.4 & 1.1 & 2.7 & 7.0 & $<0.52$ & 2.3 & 2.6 & 4.7 & 2.3 & 0.38 & $<0.21$ & $<0.042$ \\
\hline 23 & $<.049$ & $<.064$ & $<.11$ & $<.064$ & .07 & 2.7 & 1.1 & 1.4 & 2.3 & 5.7 & $<.52$ & 1.9 & 1.8 & 3.9 & 2.0 & .36 & $<.17$ & $<.042$ \\
\hline 24 & $<.049$ & $<.064$ & $<.11$ & $<.064$ & .06 & 1.8 & .77 & 1.1 & 1.5 & 3.5 & $<.52$ & 1.3 & 1.2 & 2.6 & 1.4 & .32 & $<.12$ & $<.042$ \\
\hline 25 & $<.049$ & $<.064$ & $<.11$ & $<.064$ & .13 & 3.5 & 1.6 & 2.4 & 3.0 & 6.7 & $<.52$ & 2.6 & 2.6 & 5.2 & 2.8 & .77 & $<.26$ & $<.042$ \\
\hline 37 & .12 & $<.064$ & $<.11$ & .19 & .44 & 9.6 & 4.6 & 6.2 & 8.0 & 22. & $<.52$ & 6.2 & 10 & 16 & 7.2 & 2.2 & .47 & $<.042$ \\
\hline 38 & $<.049$ & $<.064$ & $<.11$ & $<.064$ & $<.031$ & 1.2 & .49 & .42 & .82 & 2.1 & $<.52$ & .61 & .88 & 1.4 & .76 & .10 & $<.061$ & $<.042$ \\
\hline 40 & .05 & $<.064$ & $<.11$ & $<.064$ & .11 & 3.7 & 1.7 & 2.0 & 3.1 & 8.9 & $<.52$ & 2.1 & 3.1 & 5.4 & 2.6 & .54 & $<.25$ & $<.042$ \\
\hline 41 & $<.049$ & $<.064$ & $<.11$ & $<.064$ & $<.15$ & 6.2 & 2.7 & 3.4 & 5.2 & 14. & $<.52$ & 5.0 & 5.0 & 9.6 & 4.5 & .89 & $<.33$ & $<.042$ \\
\hline 43 & $<.049$ & $<.064$ & $<.11$ & $<.064$ & $<.031$ & 1.1 & .42 & .46 & .80 & 2.0 & $<.52$ & .65 & .69 & 1.3 & .75 & .13 & $<.059$ & $<.042$ \\
\hline
\end{tabular}


Table 2-8. Particle-size distributions in samples collected from a stormwater-filtration device, Madison, Wis., $2005-07$.

[All data are in percent by mass; $<$, less than; $\mu \mathrm{m}$, micrometer]

\begin{tabular}{|c|c|c|c|c|c|c|c|c|c|c|c|c|c|c|c|c|c|c|}
\hline \multirow{2}{*}{$\begin{array}{c}\text { Sampling } \\
\text { event } \\
\text { number }\end{array}$} & \multicolumn{2}{|c|}{$<500 \mu \mathrm{m}$} & \multicolumn{2}{|c|}{$<250 \mu \mathrm{m}$} & \multicolumn{2}{|c|}{$<125 \mu \mathrm{m}$} & \multicolumn{2}{|c|}{$<63 \mu \mathrm{m}$} & \multicolumn{2}{|c|}{$<31 \mu \mathrm{m}$} & \multicolumn{2}{|c|}{$<16 \mu \mathrm{m}$} & \multicolumn{2}{|c|}{$<8 \mu \mathrm{m}$} & \multicolumn{2}{|c|}{$<4 \mu \mathrm{m}$} & \multicolumn{2}{|c|}{$<2 \mu \mathrm{m}$} \\
\hline & Inlet & Outlet & Inlet & Outlet & Inlet & Outlet & Inlet & Outlet & Inlet & Outlet & Inlet & Outlet & Inlet & Outlet & Inlet & Outlet & Inlet & Outlet \\
\hline 1 & 99 & 96 & 98 & 92 & 48 & 80 & 29 & 64 & 18 & 48 & 15 & 32 & 14 & 29 & 12 & 23 & 6 & 14 \\
\hline 2 & 98 & 90 & 95 & 80 & 49 & 70 & 29 & 36 & 13 & 10 & 10 & 10 & 9 & 10 & 8 & 10 & 5 & 10 \\
\hline 4 & 97 & 96 & 74 & 91 & 50 & 87 & 48 & 67 & 41 & 58 & 29 & 50 & 26 & 47 & 22 & 42 & 13 & 24 \\
\hline 7 & 97 & 96 & 84 & 92 & 81 & 88 & 78 & 78 & 70 & 74 & 46 & 48 & 39 & 40 & 29 & 32 & 13 & 12 \\
\hline 8 & 99 & 99 & 89 & 97 & 86 & 93 & 73 & 79 & 64 & 79 & 37 & 62 & 27 & 53 & 18 & 39 & 5 & 10 \\
\hline 9 & 79 & 97 & 74 & 94 & 69 & 88 & 57 & 66 & 44 & 45 & 31 & 33 & 27 & 31 & 22 & 27 & 9 & 15 \\
\hline 10 & 98 & 96 & 78 & 91 & 74 & 87 & 56 & 66 & 38 & 39 & 27 & 33 & 23 & 30 & 16 & 24 & 5 & 12 \\
\hline 11 & 97 & 96 & 85 & 91 & 76 & 76 & 53 & 45 & 38 & 28 & 21 & 23 & 15 & 21 & 10 & 18 & 3 & 9 \\
\hline 12 & 88 & 97 & 85 & 94 & 77 & 84 & 59 & 61 & 40 & 38 & 26 & 28 & 19 & 25 & 14 & 20 & 4 & 8 \\
\hline 13 & 69 & 91 & 62 & 81 & 52 & 72 & 33 & 62 & 25 & 53 & 23 & 43 & 3 & 40 & 3 & 36 & 3 & 21 \\
\hline 15 & 92 & 88 & 84 & 75 & 64 & 63 & 42 & 50 & 27 & 38 & 22 & 33 & 20 & 28 & 17 & 13 & 8 & 13 \\
\hline 16 & 66 & 98 & 62 & 96 & 56 & 88 & 43 & 63 & 29 & 43 & 20 & 31 & 16 & 26 & 12 & 22 & 5 & 12 \\
\hline 17 & 86 & 97 & 78 & 95 & 59 & 92 & 41 & 65 & 29 & 38 & 18 & 29 & 14 & 26 & 9 & 21 & 2 & 9 \\
\hline 18 & 55 & 94 & 52 & 89 & 47 & 83 & 37 & 72 & 26 & 58 & 23 & 57 & 22 & 53 & 19 & 47 & 9 & 19 \\
\hline 19 & 81 & 93 & 70 & 86 & 52 & 80 & 45 & 73 & 24 & 50 & 19 & 46 & 17 & 39 & 16 & 34 & 13 & 23 \\
\hline 20 & 94 & 97 & 67 & 94 & 61 & 90 & 48 & 82 & 35 & 79 & 24 & 62 & 19 & 48 & 15 & 36 & 6 & 20 \\
\hline 23 & 77 & 96 & 71 & 93 & 54 & 89 & 34 & 67 & 22 & 47 & 18 & 42 & 14 & 35 & 12 & 30 & 8 & 23 \\
\hline 24 & 95 & 90 & 72 & 80 & 67 & 71 & 53 & 61 & 40 & 51 & 31 & 49 & 22 & 49 & 18 & 47 & 12 & 43 \\
\hline 25 & 70 & 95 & 68 & 90 & 60 & 78 & 40 & 60 & 24 & 47 & 23 & 47 & 23 & 45 & 22 & 44 & 21 & 40 \\
\hline 26 & 97 & 92 & 80 & 85 & 77 & 77 & 61 & 62 & 37 & 45 & 34 & 42 & 32 & 40 & 31 & 38 & 29 & 35 \\
\hline 27 & 98 & 98 & 96 & 96 & 87 & 94 & 78 & 87 & 63 & 76 & 43 & 59 & 32 & 45 & 25 & 34 & 13 & 16 \\
\hline 28 & 91 & 93 & 83 & 85 & 74 & 78 & 66 & 70 & 57 & 63 & 31 & 45 & 24 & 39 & 21 & 31 & 9 & 18 \\
\hline 29 & 89 & 89 & 77 & 77 & 66 & 66 & 55 & 55 & 43 & 43 & 36 & 34 & 34 & 27 & 27 & 11 & 11 & 11 \\
\hline 30 & 96 & 94 & 82 & 89 & 73 & 89 & 60 & 89 & 48 & 70 & 44 & 64 & 34 & 49 & 27 & 40 & 15 & 20 \\
\hline 32 & 94 & 90 & 82 & 79 & 76 & 79 & 70 & 79 & 58 & 79 & 53 & 71 & 48 & 63 & 43 & 56 & 35 & 44 \\
\hline 33 & 89 & 97 & 87 & 94 & 84 & 94 & 80 & 94 & 74 & 87 & 71 & 82 & 65 & 75 & 53 & 65 & 21 & 42 \\
\hline
\end{tabular}


Table 2-8. Particle-size distributions in samples collected from a stormwater-filtration device, Madison, Wis., 2005-07. —Continued

[All data are in percent by mass; $<$, less than; $\mu \mathrm{m}$, micrometer]

\begin{tabular}{|c|c|c|c|c|c|c|c|c|c|c|c|c|c|c|c|c|c|c|}
\hline \multirow{2}{*}{$\begin{array}{c}\text { Sampling } \\
\text { event } \\
\text { number }\end{array}$} & \multicolumn{2}{|c|}{$<500 \mu \mathrm{m}$} & \multicolumn{2}{|c|}{$<250 \mu \mathrm{m}$} & \multicolumn{2}{|c|}{$<125 \mu \mathrm{m}$} & \multicolumn{2}{|c|}{$<63 \mu \mathrm{m}$} & \multicolumn{2}{|c|}{$<31 \mu \mathrm{m}$} & \multicolumn{2}{|c|}{$<16 \mu \mathrm{m}$} & \multicolumn{2}{|c|}{$<8 \mu \mathrm{m}$} & \multicolumn{2}{|c|}{$<4 \mu \mathrm{m}$} & \multicolumn{2}{|c|}{$<2 \mu \mathrm{m}$} \\
\hline & Inlet & Outlet & Inlet & Outlet & Inlet & Outlet & Inlet & Outlet & Inlet & Outlet & Inlet & Outlet & Inlet & Outlet & Inlet & Outlet & Inlet & Outlet \\
\hline 34 & 98 & 97 & 91 & 94 & 80 & 82 & 61 & 69 & 49 & 58 & 48 & 55 & 44 & 49 & 38 & 42 & 21 & 25 \\
\hline 36 & 97 & 97 & 94 & 95 & 91 & 87 & 76 & 70 & 63 & 52 & 59 & 43 & 51 & 32 & 46 & 26 & 36 & 15 \\
\hline 37 & 91 & 86 & 82 & 71 & 73 & 71 & 73 & 71 & 73 & 71 & 71 & 69 & 67 & 66 & 62 & 63 & 53 & 60 \\
\hline 38 & 97 & 95 & 84 & 90 & 71 & 90 & 42 & 65 & 27 & 45 & 26 & 44 & 25 & 41 & 24 & 39 & 20 & 35 \\
\hline 40 & 99 & 98 & 88 & 96 & 79 & 91 & 59 & 71 & 36 & 48 & 34 & 47 & 31 & 45 & 29 & 43 & 20 & 38 \\
\hline 41 & 97 & 67 & 94 & 33 & 90 & 33 & 79 & 33 & 57 & 33 & 55 & 33 & 52 & 33 & 49 & 33 & 40 & 33 \\
\hline 42 & 95 & 90 & 90 & 79 & 86 & 79 & 67 & 79 & 52 & 79 & 50 & 73 & 47 & 65 & 46 & 56 & 39 & 40 \\
\hline 43 & 90 & 95 & 84 & 90 & 77 & 90 & 66 & 70 & 51 & 52 & 48 & 48 & 46 & 41 & 43 & 37 & 26 & 29 \\
\hline 44 & 90 & 95 & 87 & 90 & 84 & 90 & 71 & 79 & 55 & 60 & 53 & 53 & 51 & 45 & 48 & 39 & 30 & 30 \\
\hline 45 & 93 & 91 & 87 & 82 & 80 & 82 & 60 & 82 & 45 & 57 & 43 & 54 & 41 & 46 & 39 & 41 & 27 & 30 \\
\hline
\end{tabular}


Table 2-9. Loads of suspended solids, suspended sediment, volatile solids, and dissolved solids in stormwater samples collected from a stormwater-filtration device, Madison, Wis., 2005-07.

[All data in pounds; --, no sample processed for event]

\begin{tabular}{|c|c|c|c|c|c|c|c|c|}
\hline \multirow{2}{*}{$\begin{array}{c}\text { Sampling } \\
\text { event } \\
\text { number }\end{array}$} & \multicolumn{2}{|c|}{$\begin{array}{c}\text { Suspended solids, } \\
\text { total }\end{array}$} & \multicolumn{2}{|c|}{$\begin{array}{l}\text { Concentrations of } \\
\text { suspended sediment }\end{array}$} & \multicolumn{2}{|c|}{ Solids, volatile } & \multicolumn{2}{|c|}{ Solids, dissolved } \\
\hline & Inlet & Outlet & Inlet & Outlet & Inlet & Outlet & Inlet & Outlet \\
\hline 1 & 1.8 & 1.0 & 2.8 & 0.9 & -- & -- & -- & -- \\
\hline 2 & 1.0 & .7 & 1.9 & .6 & -- & -- & -- & -- \\
\hline 3 & 3.1 & 2.0 & 3.9 & 1.9 & -- & -- & 6.9 & 7.0 \\
\hline 4 & 5.2 & 6.3 & 5.8 & 6.6 & -- & -- & 8.2 & 11.3 \\
\hline 5 & .8 & .3 & .8 & .3 & -- & -- & 1.6 & 2.0 \\
\hline 6 & 2.1 & 2.1 & 2.4 & 1.9 & -- & -- & -- & -- \\
\hline 7 & 16.8 & 11.1 & 18.5 & 11.1 & 3.7 & 2.7 & -- & -- \\
\hline 8 & 1.1 & 1.1 & 1.5 & 1.1 & .3 & .3 & -- & -- \\
\hline 9 & 4.7 & 2.7 & 6.0 & 2.7 & 1.3 & .8 & -- & -- \\
\hline 10 & .6 & .5 & .6 & .5 & .2 & .2 & -- & -- \\
\hline 11 & 2.8 & 1.6 & 3.0 & 1.6 & .9 & .5 & -- & -- \\
\hline 12 & 9.2 & .1 & .7 & .1 & .9 & .1 & -- & -- \\
\hline 13 & .6 & .2 & .7 & .2 & .5 & -- & -- & -- \\
\hline 14 & 1.7 & .3 & 1.7 & .3 & -- & -- & -- & -- \\
\hline 15 & 5.4 & 1.8 & 4.1 & 1.6 & 2.9 & .8 & -- & -- \\
\hline 16 & 1.5 & .9 & 2.5 & .8 & .6 & .4 & -- & -- \\
\hline 17 & .9 & .5 & 1.4 & .4 & .3 & .2 & -- & -- \\
\hline 18 & .8 & .6 & 1.4 & .5 & .3 & .2 & -- & -- \\
\hline 19 & 9.3 & 7.1 & 11.8 & 5.7 & 3.0 & 2.3 & -- & -- \\
\hline 20 & .9 & .5 & .8 & .3 & .3 & -- & -- & -- \\
\hline 21 & 2.6 & 2.1 & 2.7 & 2.1 & -- & -- & -- & 3.2 \\
\hline 22 & .3 & .2 & .3 & .2 & -- & -- & -- & -- \\
\hline 23 & .4 & .3 & .6 & .2 & .1 & .1 & -- & -- \\
\hline 24 & 3.4 & 1.2 & 3.2 & 1.0 & 1.0 & -- & -- & -- \\
\hline 25 & 1.9 & 2.0 & 1.5 & 1.4 & 1.0 & .6 & -- & -- \\
\hline 26 & .1 & .4 & 1.0 & .4 & -- & -- & -- & -- \\
\hline 27 & .0 & .7 & .8 & .7 & .3 & .2 & -- & -- \\
\hline 28 & .2 & .2 & .2 & .2 & .1 & .1 & -- & -- \\
\hline 29 & .1 & .1 & .3 & .3 & -- & -- & -- & -- \\
\hline 30 & .7 & .4 & 2.3 & .4 & -- & -- & -- & -- \\
\hline 31 & .3 & .1 & .3 & .1 & -- & -- & -- & -- \\
\hline 32 & .1 & .1 & .1 & .1 & .1 & .0 & -- & -- \\
\hline 33 & 2.9 & 2.2 & 2.9 & 1.9 & 1.2 & .9 & 7.7 & 8.2 \\
\hline 34 & 2.9 & 2.8 & 2.8 & 2.8 & 1.2 & 1.3 & -- & -- \\
\hline 35 & 2.5 & 1.9 & 2.9 & 2.4 & .6 & .9 & -- & -- \\
\hline 36 & 2.4 & 2.3 & 3.6 & 2.6 & .8 & .6 & -- & -- \\
\hline
\end{tabular}


Table 2-9. Loads of suspended solids, suspended sediment, volatile solids, and dissolved solids in stormwater samples collected from a stormwater-filtration device, Madison, Wis., 2005-07. —Continued

[All data in pounds; --, no sample processed for event]

\begin{tabular}{|c|c|c|c|c|c|c|c|c|}
\hline \multirow{2}{*}{$\begin{array}{l}\text { Sampling } \\
\text { event } \\
\text { number }\end{array}$} & \multicolumn{2}{|c|}{$\begin{array}{c}\text { Suspended solids, } \\
\text { total }\end{array}$} & \multicolumn{2}{|c|}{$\begin{array}{c}\text { Concentrations of } \\
\text { suspended sediment }\end{array}$} & \multicolumn{2}{|c|}{ Solids, volatile } & \multicolumn{2}{|c|}{ Solids, dissolved } \\
\hline & Inlet & Outlet & Inlet & Outlet & Inlet & Outlet & Inlet & Outlet \\
\hline 37 & 4.6 & 5.7 & 4.9 & 5.9 & 2.1 & 1.5 & -- & -- \\
\hline 38 & .3 & .1 & .3 & .2 & -- & -- & -- & -- \\
\hline 39 & .0 & .0 & .1 & .0 & -- & -- & -- & -- \\
\hline 40 & .8 & .5 & .8 & .4 & .3 & .2 & -- & -- \\
\hline 41 & 3.1 & 1.8 & 3.4 & 2.0 & 1.1 & .6 & -- & -- \\
\hline 42 & -- & -- & -- & -- & -- & -- & -- & -- \\
\hline 43 & .4 & .2 & .4 & .2 & .1 & .1 & -- & -- \\
\hline 44 & 1.1 & 1.0 & .9 & .7 & .5 & .4 & -- & 3.9 \\
\hline 45 & 1.5 & 1.8 & 1.8 & 1.3 & 1.8 & 1.3 & -- & -- \\
\hline 46 & -- & -- & 1.0 & .6 & -- & -- & -- & -- \\
\hline 47 & -- & -- & .9 & .9 & -- & -- & -- & -- \\
\hline 48 & -- & -- & .7 & .5 & -- & -- & -- & -- \\
\hline 49 & -- & -- & .9 & .9 & -- & -- & -- & -- \\
\hline 50 & -- & -- & .2 & .1 & -- & -- & -- & -- \\
\hline 51 & -- & -- & 2.6 & 3.6 & -- & -- & -- & -- \\
\hline
\end{tabular}


Table 2-10. Loads of selected constituents in stormwater samples collected from a stormwater-filtration device, Madison, Wis., $2005-07$.

[All loads in pounds; --, no sample processed for event]

\begin{tabular}{|c|c|c|c|c|c|c|c|c|c|c|c|c|c|c|c|c|}
\hline \multirow[t]{2}{*}{$\begin{array}{c}\text { Sampling } \\
\text { event } \\
\text { number }\end{array}$} & \multicolumn{2}{|c|}{$\begin{array}{l}\text { Chemical } \\
\text { oxygen } \\
\text { demand, } \\
\text { total }\end{array}$} & \multicolumn{2}{|c|}{$\begin{array}{c}\text { Phosphorus, } \\
\text { total }\end{array}$} & \multicolumn{2}{|c|}{$\begin{array}{l}\text { Phosphorus, } \\
\text { dissolved }\end{array}$} & \multicolumn{2}{|c|}{$\begin{array}{l}\text { Chloride, } \\
\text { dissolved }\end{array}$} & \multicolumn{2}{|c|}{$\begin{array}{l}\text { Copper, } \\
\text { dissolved }\end{array}$} & \multicolumn{2}{|c|}{$\begin{array}{c}\text { Copper, } \\
\text { total } \\
\text { recoverable }\end{array}$} & \multicolumn{2}{|c|}{$\begin{array}{c}\text { Zinc, } \\
\text { dissolved }\end{array}$} & \multicolumn{2}{|c|}{$\begin{array}{c}\text { Zinc, } \\
\text { total } \\
\text { recoverable }\end{array}$} \\
\hline & Inlet & Outlet & Inlet & Outlet & Inlet & Outlet & Inlet & Outlet & Inlet & Outlet & Inlet & Outlet & Inlet & Outlet & Inlet & Outlet \\
\hline 1 & 0.6 & 1.9 & 0.011 & 0.010 & 0.0077 & 0.008 & 0.22 & 0.25 & 0.0002 & 0.0002 & 0.0004 & 0.0004 & 0.0010 & 0.0010 & 0.0010 & 0.0010 \\
\hline 2 & 2.3 & 1.6 & .0086 & .0071 & .0047 & .0043 & .22 & .27 & .00005 & .00005 & .00021 & .00031 & -- & -- & .00186 & .00186 \\
\hline 3 & -- & -- & -- & -- & -- & -- & 2.84 & 3.01 & -- & -- & -- & -- & -- & -- & -- & -- \\
\hline 4 & -- & -- & -- & -- & -- & -- & 2.41 & 4.08 & -- & -- & -- & -- & -- & -- & -- & -- \\
\hline 5 & -- & -- & -- & -- & -- & -- & .44 & .57 & -- & -- & -- & -- & -- & -- & -- & -- \\
\hline 6 & 1.4 & 7.0 & .0050 & .0048 & .0137 & .0024 & .61 & .63 & .00031 & .00027 & .00064 & .00048 & -- & -- & .00273 & .00289 \\
\hline 7 & 13 & 7.2 & .0213 & .0161 & .0054 & .0059 & .62 & .57 & .00044 & .00040 & .00173 & .00148 & .00198 & .00247 & .01087 & .00914 \\
\hline 8 & 1.0 & .94 & .0858 & .0021 & .0009 & .0009 & .18 & .20 & .00012 & .00010 & .00021 & .00017 & .00026 & .00047 & .00099 & .00107 \\
\hline 9 & 3.5 & 1.7 & .0079 & .0059 & .0027 & .0016 & .24 & .25 & .00007 & .00013 & .00053 & .00040 & .00080 & .00147 & .00574 & .00267 \\
\hline 10 & .52 & .63 & .0019 & .0016 & .0009 & .0008 & .06 & .09 & .00002 & .00002 & .00008 & .00008 & .00032 & .00056 & .00071 & .00087 \\
\hline 11 & .30 & 1.1 & .0012 & .0034 & .0045 & .0014 & .09 & .09 & .00003 & .00003 & .00020 & .00013 & .00039 & .00059 & .00164 & .00145 \\
\hline 12 & 1.2 & .77 & .0028 & .0018 & .0016 & .0013 & .09 & .11 & .00012 & .00013 & .00019 & .00019 & .00039 & .00053 & .00092 & .00068 \\
\hline 13 & .52 & 1.6 & .0067 & .0051 & .0049 & .0035 & -- & .22 & .00046 & .00027 & .00035 & .00035 & .00139 & .00150 & .00150 & .00174 \\
\hline 14 & -- & -- & -- & -- & -- & -- & .09 & .10 & -- & -- & -- & -- & -- & -- & -- & -- \\
\hline 15 & 2.6 & 1.9 & .0059 & .0047 & .0021 & .0014 & .10 & -- & .00011 & .00011 & .00037 & .00027 & .00043 & .00048 & .00197 & .00165 \\
\hline 16 & 1.4 & .87 & .0037 & .0045 & .0027 & .0029 & .09 & .10 & .00019 & .00019 & .00025 & .00025 & .00037 & .00056 & .00105 & .00118 \\
\hline 17 & 1.3 & 1.2 & .0051 & .0056 & .0031 & .0023 & .13 & .14 & .00019 & .00022 & .00080 & .00030 & .00060 & .00111 & .00201 & .00161 \\
\hline 18 & 1.7 & 1.7 & .0129 & .0125 & .0084 & .0087 & .38 & .38 & .00140 & .00095 & .00228 & .00190 & .00304 & .00304 & .00531 & .00494 \\
\hline 19 & 3.7 & 1.7 & .0094 & .0084 & .0053 & .0059 & .13 & .14 & .00030 & .00029 & .00151 & .00058 & .00093 & .00105 & .00384 & .00244 \\
\hline 20 & .64 & .83 & .0028 & .0034 & .0019 & .0025 & .07 & .08 & .00006 & .00006 & .00019 & .00019 & .00058 & .00058 & .00103 & .00096 \\
\hline 21 & -- & -- & -- & -- & -- & -- & .03 & .04 & -- & -- & -- & -- & -- & -- & -- & -- \\
\hline 22 & -- & -- & -- & -- & -- & -- & .02 & .03 & -- & -- & -- & -- & -- & -- & -- & -- \\
\hline 23 & 4.7 & 5.6 & .0089 & .0069 & .0047 & .0051 & .13 & -- & .00006 & .00006 & .00067 & .00051 & .00135 & .00168 & .00455 & .00320 \\
\hline 24 & 1.9 & -- & .0038 & .0033 & .0020 & .0019 & .10 & .11 & .00006 & .00006 & .00038 & .00025 & .00113 & .00113 & .00251 & .00188 \\
\hline 25 & 1.4 & 2.1 & .0022 & .0024 & .0009 & .0003 & .09 & .10 & .00006 & .00006 & .00033 & .00033 & .00122 & .00122 & .00199 & .00222 \\
\hline 26 & -- & -- & -- & -- & -- & -- & -- & .06 & -- & -- & -- & -- & -- & -- & -- & -- \\
\hline
\end{tabular}


Table 2-10. Loads of selected constituents in stormwater samples collected from a stormwater-filtration device, Madison, Wis., 2005-07. —Continued

[All loads in pounds; --, no sample processed for event]

\begin{tabular}{|c|c|c|c|c|c|c|c|c|c|c|c|c|c|c|c|c|}
\hline \multirow[t]{2}{*}{$\begin{array}{l}\text { Sampling } \\
\text { event } \\
\text { number }\end{array}$} & \multicolumn{2}{|c|}{$\begin{array}{l}\text { Chemical } \\
\text { oxygen } \\
\text { demand, } \\
\text { total }\end{array}$} & \multicolumn{2}{|c|}{$\begin{array}{c}\text { Phosphorus, } \\
\text { total }\end{array}$} & \multicolumn{2}{|c|}{$\begin{array}{c}\text { Phosphorus, } \\
\text { dissolved }\end{array}$} & \multicolumn{2}{|c|}{$\begin{array}{l}\text { Chloride, } \\
\text { dissolved }\end{array}$} & \multicolumn{2}{|c|}{$\begin{array}{c}\text { Copper, } \\
\text { dissolved }\end{array}$} & \multicolumn{2}{|c|}{$\begin{array}{c}\text { Copper, } \\
\text { total } \\
\text { recoverable }\end{array}$} & \multicolumn{2}{|c|}{$\begin{array}{c}\text { Zinc, } \\
\text { dissolved }\end{array}$} & \multicolumn{2}{|c|}{$\begin{array}{c}\text { Zinc, } \\
\text { total } \\
\text { recoverable }\end{array}$} \\
\hline & Inlet & Outlet & Inlet & Outlet & Inlet & Outlet & Inlet & Outlet & Inlet & Outlet & Inlet & Outlet & Inlet & Outlet & Inlet & Outlet \\
\hline 27 & 1.6 & 1.4 & 0.0037 & 0.0032 & 0.0023 & 0.0020 & 0.05 & 0.07 & 0.00008 & 0.00012 & 0.00027 & 0.00020 & 0.00035 & 0.00055 & 0.00129 & 0.00117 \\
\hline 28 & .60 & .60 & .0048 & .0050 & .0038 & .0038 & .11 & .11 & .00013 & .00013 & .00013 & .00013 & .00053 & .00106 & .00133 & .00186 \\
\hline 29 & -- & -- & -- & -- & -- & -- & .06 & .06 & -- & -- & -- & -- & -- & -- & -- & -- \\
\hline 30 & -- & -- & -- & -- & -- & -- & .04 & .04 & -- & -- & -- & -- & -- & -- & -- & -- \\
\hline 32 & 3.5 & 2.1 & .0032 & .0037 & .0022 & .0021 & .13 & .16 & .00015 & .00015 & .00015 & .00015 & .00118 & .00191 & .00206 & .00250 \\
\hline 33 & 1.3 & 1.2 & .0037 & .0032 & .0013 & .0012 & 1.45 & 1.29 & .00007 & .00007 & .00037 & .00029 & .00073 & .00117 & .00227 & .00220 \\
\hline 34 & -- & -- & -- & -- & -- & -- & .34 & .40 & -- & -- & -- & -- & -- & -- & -- & -- \\
\hline 35 & 7.5 & 5.5 & .0135 & .0130 & .0024 & .0024 & .47 & .70 & .00016 & .00016 & .00130 & .00114 & .00162 & .00227 & .00828 & .00877 \\
\hline 36 & 3.1 & 3.3 & .0080 & .0082 & .0033 & .0036 & .49 & .57 & .00026 & .00026 & .00077 & .00051 & .00180 & .00257 & .00488 & .00565 \\
\hline 37 & .98 & .85 & .0029 & .0030 & .0015 & .0017 & -- & .22 & .00007 & .00007 & .00026 & .00026 & .00039 & .00072 & .00143 & .00189 \\
\hline 38 & .07 & .07 & .0004 & .0004 & .0002 & .0003 & .03 & .04 & .00001 & .00001 & .00003 & .00004 & .00007 & .00019 & .00016 & .00028 \\
\hline 40 & 2.0 & 1.9 & .0052 & .0063 & .0023 & .0024 & .17 & .18 & .00031 & .00031 & .00039 & .00023 & .00085 & .00132 & .00210 & .00217 \\
\hline 41 & 2.4 & 1.6 & .0063 & .0057 & .0028 & .0021 & .15 & .19 & .00021 & .00026 & .00042 & .00042 & .00073 & .00099 & .00209 & .00214 \\
\hline 43 & 1.2 & 1.3 & .0023 & .0025 & .0015 & .0016 & .04 & .05 & .00007 & .00007 & .00015 & .00011 & .00030 & .00048 & .00070 & .00070 \\
\hline 44 & 3.3 & 4.3 & .0054 & .0057 & .0039 & .0028 & .14 & .16 & .00030 & .00022 & .00045 & .00030 & .00164 & .00149 & .00246 & .00223 \\
\hline
\end{tabular}


Table 2-11. Loads of selected polycyclic aromatic hydrocarbons in stormwater samples collected from a stormwater-filtration device, Madison, Wis., 2005-07.

[All data in pounds; --, no sample processed for event]

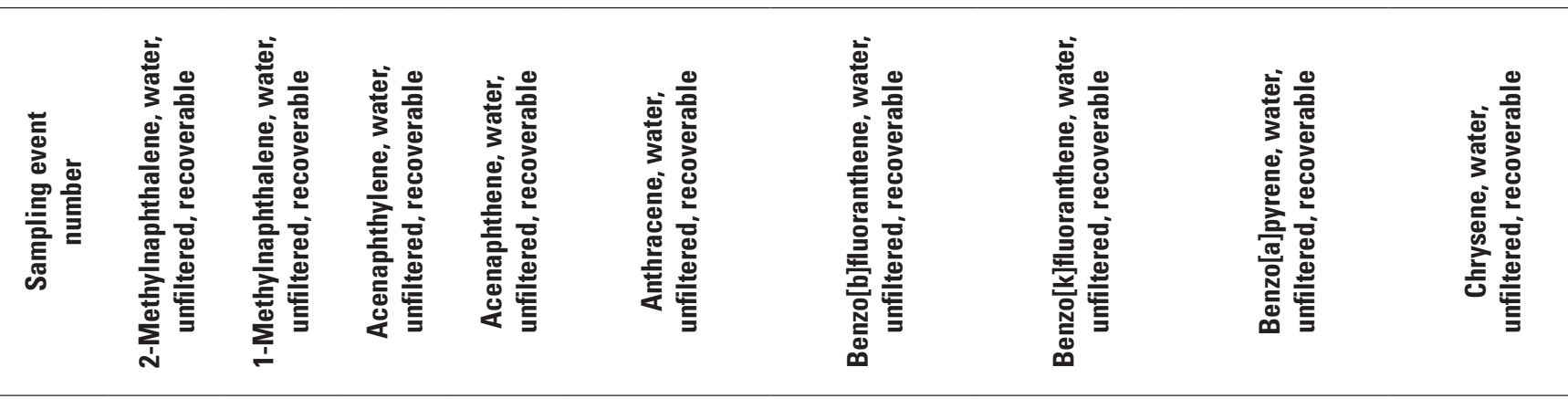

\begin{tabular}{|c|c|c|c|c|c|c|c|c|c|}
\hline \multicolumn{10}{|c|}{ Inlet } \\
\hline 10 & -- & -- & -- & -- & $9.91131 \mathrm{E}-06$ & 0.000206155 & $9.51486 \mathrm{E}-05$ & 0.000111007 & 0.000182368 \\
\hline 11 & -- & -- & -- & -- & $6.3742 \mathrm{E}-05$ & .001182841 & .00053885 & .00078856 & .001117127 \\
\hline 13 & -- & -- & -- & -- & $6.01522 \mathrm{E}-06$ & .000196651 & $7.86605 \mathrm{E}-05$ & 7.6347E-05 & .000161948 \\
\hline 16 & -- & -- & -- & -- & $1.17632 \mathrm{E}-05$ & .000247647 & .00010525 & .000111441 & .000222882 \\
\hline 17 & -- & -- & -- & -- & $3.21507 \mathrm{E}-05$ & .000522448 & .000231083 & .000190895 & .00048226 \\
\hline 18 & -- & -- & -- & -- & 5.31464E-05 & .001290698 & .000569425 & .000296101 & .001176812 \\
\hline 19 & -- & -- & -- & -- & 4.18393E-05 & .000871653 & .000418393 & .000476503 & .000813542 \\
\hline 23 & -- & -- & -- & -- & $5.0507 \mathrm{E}-05$ & .001363688 & .000622919 & .000925961 & .001195332 \\
\hline 24 & -- & -- & -- & -- & $3.01087 \mathrm{E}-05$ & .000677445 & .000313632 & .000489266 & .000589628 \\
\hline 25 & -- & -- & -- & -- & $3.2129 \mathrm{E}-05$ & .00053179 & .000243737 & .000398842 & .000476395 \\
\hline 37 & -- & -- & -- & -- & $2.28096 \mathrm{E}-05$ & .000638669 & .000299783 & .000371471 & .00054743 \\
\hline 38 & -- & -- & -- & -- & $8.35809 \mathrm{E}-07$ & $3.0793 \mathrm{E}-05$ & $1.61296 \mathrm{E}-05$ & $1.23172 \mathrm{E}-05$ & $2.6394 \mathrm{E}-05$ \\
\hline 40 & -- & -- & -- & -- & $1.94153 \mathrm{E}-05$ & .000497032 & .000217452 & .000287347 & .000427137 \\
\hline 41 & -- & -- & -- & -- & -- & .000521362 & .000250254 & .000318031 & .000458799 \\
\hline 43 & -- & -- & -- & -- & $1.22194 \mathrm{E}-06$ & $1.85735 \mathrm{E}-05$ & $8.79799 \mathrm{E}-06$ & $1.17307 \mathrm{E}-05$ & $1.7596 \mathrm{E}-05$ \\
\hline \multicolumn{10}{|c|}{ Outlet } \\
\hline 10 & -- & -- & -- & -- & 5.94679E-06 & .00016651 & $7.13615 \mathrm{E}-05$ & $8.3255 \mathrm{E}-05$ & .000134794 \\
\hline 11 & -- & -- & -- & -- & 3.21996E-05 & .000722847 & .000315424 & .000420566 & .000624277 \\
\hline 13 & -- & -- & -- & -- & -- & .000105266 & 4.16438E-05 & $3.81735 \mathrm{E}-05$ & 7.17199E-05 \\
\hline 16 & -- & -- & -- & -- & 4.39574E-06 & .000160971 & $6.81029 \mathrm{E}-05$ & $5.2625 \mathrm{E}-05$ & .000136206 \\
\hline 17 & -- & -- & -- & -- & 4.42072E-06 & .000231083 & $9.34379 \mathrm{E}-05$ & $4.21978 \mathrm{E}-05$ & .000200942 \\
\hline 18 & -- & -- & -- & -- & $3.22674 \mathrm{E}-05$ & .000873119 & .000368228 & .000144254 & .000721272 \\
\hline 19 & -- & -- & -- & -- & 1.39464E-05 & .000371905 & .000162708 & .000127842 & .000313795 \\
\hline 23 & -- & -- & -- & -- & $1.24584 \mathrm{E}-05$ & .000454563 & .000185192 & .000235699 & .00038722 \\
\hline 24 & -- & -- & -- & -- & 7.02536E-06 & .000225815 & $9.65987 \mathrm{E}-05$ & .000137998 & .000188179 \\
\hline 25 & -- & -- & -- & -- & $1.44026 \mathrm{E}-05$ & .000387763 & .000177263 & .000265895 & .000332368 \\
\hline 37 & -- & -- & -- & -- & $2.86749 \mathrm{E}-05$ & .000625635 & .000299783 & .000404056 & .000521362 \\
\hline 38 & -- & -- & -- & -- & -- & $1.7596 \mathrm{E}-05$ & 7.18502E-06 & $6.15859 \mathrm{E}-06$ & $1.20239 \mathrm{E}-05$ \\
\hline 40 & -- & -- & -- & -- & $8.54274 \mathrm{E}-06$ & .000287347 & .000132024 & .000155323 & .00024075 \\
\hline 41 & -- & -- & -- & -- & -- & .000323245 & .000140768 & .000177263 & .000271108 \\
\hline 43 & -- & -- & -- & -- & -- & $5.37655 \mathrm{E}-06$ & $2.05286 \mathrm{E}-06$ & $2.24837 \mathrm{E}-06$ & $3.91022 \mathrm{E}-06$ \\
\hline
\end{tabular}


Table 2-11. Loads of selected polycyclic aromatic hydrocarbons in stormwater samples collected from a stormwater-filtration device, Madison, Wis., 2005-07. - Continued

[All data in pounds; --, no sample processed for event]

\begin{tabular}{|c|c|c|c|c|c|c|c|c|c|}
\hline 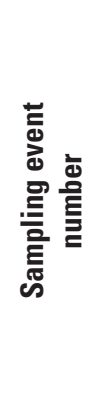 & 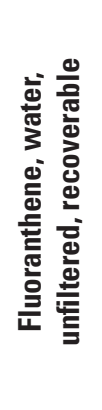 & 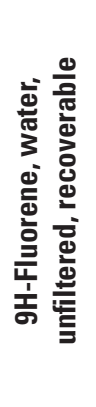 & 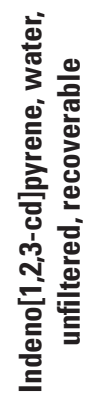 & 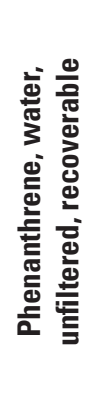 & 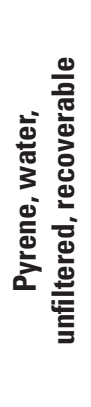 & 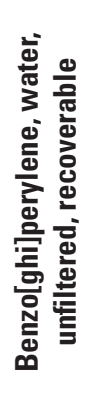 & 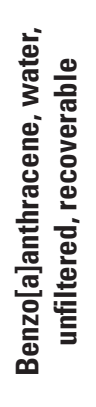 & 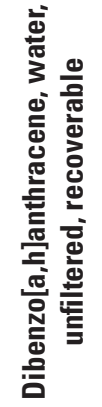 & 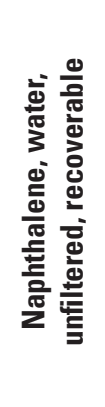 \\
\hline
\end{tabular}

\begin{tabular}{|c|c|c|c|c|c|c|c|c|c|}
\hline \multicolumn{10}{|c|}{ Inlet } \\
\hline 11 & .003088528 & -- & .000854274 & .001708548 & .002365681 & .000919987 & .000328567 & -- & -- \\
\hline 13 & .000428006 & -- & .000127245 & .000161948 & .000289193 & .000138813 & $1.96651 \mathrm{E}-05$ & -- & -- \\
\hline 16 & .000681029 & -- & .000173353 & .000253838 & .000439574 & .000185735 & -- & -- & -- \\
\hline 17 & .001507063 & -- & .000381789 & .000733437 & .001004709 & .000411931 & -- & -- & -- \\
\hline 19 & .002208187 & -- & .000615968 & .000836786 & .001627085 & .000662456 & .000220819 & -- & -- \\
\hline 23 & .003030418 & -- & .000993304 & .001060646 & .002188635 & .001060646 & .000303042 & -- & -- \\
\hline 24 & .001505434 & -- & .000514356 & .000526902 & .001129075 & .000539447 & .000188179 & -- & -- \\
\hline 25 & .001218684 & -- & .000387763 & .000443158 & .000963869 & .000421 & .000188342 & -- & -- \\
\hline 41 & .001303406 & -- & .000323245 & .000458799 & .000886316 & .000385808 & $9.38452 \mathrm{E}-05$ & -- & -- \\
\hline 43 & $5.37655 \mathrm{E}-05$ & -- & $1.17307 \mathrm{E}-05$ & $2.00399 \mathrm{E}-05$ & $3.56807 \mathrm{E}-05$ & $1.36858 \mathrm{E}-05$ & 4.74114E-06 & -- & -- \\
\hline \multicolumn{10}{|c|}{ Outlet } \\
\hline 10 & .000344914 & -- & .000118936 & .000174439 & .000261659 & .000126865 & $2.25978 \mathrm{E}-05$ & -- & -- \\
\hline 11 & .001642834 & -- & .000499422 & .000854274 & .001248554 & .000551992 & .000164283 & -- & -- \\
\hline 13 & .000185084 & -- & 7.17199E-05 & 6.94064E-05 & .00011452 & $6.13089 \mathrm{E}-05$ & -- & -- & -- \\
\hline 16 & .000365279 & -- & .000111441 & .000167162 & .000247647 & .000117632 & -- & -- & -- \\
\hline 17 & .000522448 & -- & .000160753 & .0001708 & .000351648 & .0001708 & -- & -- & -- \\
\hline 18 & .002163816 & -- & .000607387 & .000797196 & .001404583 & .000645349 & -- & -- & -- \\
\hline 38 & $3.0793 \mathrm{E}-05$ & -- & 8.94462E-06 & $1.29037 \mathrm{E}-05$ & $2.05286 \mathrm{E}-05$ & $1.11441 \mathrm{E}-05$ & $1.437 \mathrm{E}-06$ & -- & -- \\
\hline 40 & .000691185 & -- & .000163089 & .00024075 & .000419371 & .000201919 & 4.19371E-05 & -- & -- \\
\hline 41 & .000729907 & -- & .000260681 & .000260681 & .000500508 & .000234613 & 4.64012E-05 & -- & -- \\
\hline 43 & $9.77554 \mathrm{E}-06$ & -- & $3.17705 \mathrm{E}-06$ & $3.37256 \mathrm{E}-06$ & $6.3541 \mathrm{E}-06$ & $3.66583 \mathrm{E}-06$ & $6.3541 \mathrm{E}-07$ & -- & -- \\
\hline
\end{tabular}


[mg/L, milligrams per liter; $\mu \mathrm{g} / \mathrm{L}$, micrograms per liter; --, no data available]

\begin{tabular}{|c|c|c|c|c|c|c|c|}
\hline Study & $\begin{array}{l}\text { Total } \\
\text { suspended } \\
\text { solids } \\
\text { (mg/L) }\end{array}$ & $\begin{array}{c}\text { Suspended } \\
\text { sediment } \\
\text { concentration } \\
\text { (mg/L) }\end{array}$ & $\begin{array}{c}\text { Dissolved } \\
\text { phosphorus } \\
\text { (mg/L) }\end{array}$ & $\begin{array}{c}\text { Total } \\
\text { phosphorus } \\
\text { (mg/L) }\end{array}$ & $\begin{array}{l}\text { Total } \\
\text { copper } \\
\text { (pg /L) }\end{array}$ & $\begin{array}{c}\text { Total } \\
\text { zinc } \\
(\mu \mathrm{g} / \mathrm{L})\end{array}$ & $\begin{array}{c}\text { Mean } \\
\text { percentage } \\
\text { of sand }\end{array}$ \\
\hline Madison Gas and Electric Company, Madison & 20 & 21 & 0.03 & 0.11 & 4.9 & 25 & 43 \\
\hline $\begin{array}{l}\text { City of Madison Water Utility, Madison (U.S. Environmental } \\
\text { Protection Agency, 2004) }\end{array}$ & 96 & 121 & .088 & .20 & 5.1 & 47 & 49 \\
\hline St. Mary’s Hospital parking lot, Green Bay (Horwatich, 2000) & 36 & 127 & .021 & .082 & -- & 56 & 26 \\
\hline City maintenance yard, Madison (Waschbusch, 1999) & 180 & -- & .12 & .34 & 17 & 193 & -- \\
\hline City garage \& parking lot, Milwaukee (Corsi and others, 1999) & 259 & -- & .011 & .26 & 30 & 154 & 10 \\
\hline Commercial strip, Madison (Waschbusch and others, 1999) & 50 & -- & .016 & .09 & -- & -- & -- \\
\hline Commercial strip, Marquette, Mich., (Steuer and others, 1997) & 138 & -- & .22 & .21 & 25 & 178 & -- \\
\hline Commercial strip, Madison (Bannerman and others, 1993) & 58 & -- & .05 & .19 & 9 & 330 & -- \\
\hline $\begin{array}{l}\text { Commercial strip, Milwaukee (Bannerman and others, 1983; } \\
\text { Post Office) }\end{array}$ & 116 & -- & .05 & .26 & -- & 210 & -- \\
\hline $\begin{array}{l}\text { Shopping Center, Milwaukee (Bannerman and others, 1983; } \\
\text { Rustler) }\end{array}$ & 38 & -- & .026 & .101 & -- & 131 & 50 \\
\hline
\end{tabular}


Publishing support provided by the U.S. Geological Survey Publishing Network, Columbus Publishing Service Center

For more information concerning the research in this report, contact the Director, Wisconsin Water Science Center

U.S. Geological Survey

8505 Research Way

Middleton, Wisconsin 53562

http://wi.water.usgs.gov/ 
